\title{
WHAT DO WORKERS WANT? \\ EMPLOYEE INTERESTS, PUBLIC INTERESTS, AND \\ FREEDOM OF EXPRESSION UNDER THE \\ NATIONAL LABOR RELATIONS ACT
}

\author{
CYNTHIA L. ESTLUND†
}

\section{INTRODUCTION}

Consider the following scenario: Several employees engaged in the construction of a nuclear facility detect improper construction practices that they believe will render the plant fundamentally unsafe and a threat to the surrounding community. Together the employees raise these concerns with their employer and, when they are ignored, with regulatory officials. As a result the employees are fired. They file a charge against their employer under the National Labor Relations Act (NLRA), ${ }^{1}$ asserting their right, under section 7 of the Act, to engage in "concerted activities for the purpose of ... mutual aid or protection." 2 The disposition of the employees' charge is predictable: they are unlikely even to get a hearing. The reason? The employees' concern was for the future safety of the public, not for their own working conditions. ${ }^{3}$

Had these private sector employees been fired for complaining . about the most trivial conditions of employment-say, the number

† Assistant Professor, University of Texas School of Law; B.A. 1978, Lawrence University; J.D. 1983, Yale Law School. I would like to thank Jack Getman, Mike Gottesman, Sam Issacharoff, Doug Laycock, David Rabban, John Robertson, Charles Silver, Jordan Steiker, and Mark Yudof for their helpful comments on earlier drafts of this Article, and Carmel Martin, Gary Truman, Denise Acebo, and Steve Phelps for their able research assistance. I would also like to thank the Center for Labor Relations Studies for its support.

129 U.S.C. $\$ \S 151-169$ (1988).

2 Section 7 of the NLRA declares in pertinent part as follows: "Employees shall have the right to self-organization, to form, join, or assist labor organizations, to bargain collectively through representatives of their own choosing, and to engage in other concerted activities for the purpose of collective bargaining or other mutual aid or protection ...." 29 U.S.C. $\$ 157$ (1988) (emphasis added). Section 8(a)(1) of the NLRA makes it an unfair labor practice for an employer to "interfere with, restrain, or coerce employees in the exercise of the rights guaranteed" by $\S 7$. 29 U.S.C. $\$ 158(a)(1)$ (1988). Discharging an employee for engaging in protected activity has been held to constitute an unfair labor practice. See NLRB v. Washington Aluminum Co., 370 U.S. 9, 12-14 (1962).

${ }^{3}$ I make this prediction with some confidence because the case is not entirely hypothetical. See Daniel Int'l, 104 L.R.R.M. (BNA) 1496 (1980) (advice memorandum of NLRB General Counsel), described infra text accompanying notes 95-97. 
of portable toilets at the construction site-they would likely have been entitled to reinstatement under the NLRA. But the safety of the public, which these employees believed to be imperiled by the work they were doing for their employer, is not deemed a proper concern of employees under the Act; it does not come within the realm of "mutual aid or protection."

This seeming anomaly-the privileging of material self-interest over moral responsibility under section 7-is all the more striking to those familiar with the law governing the speech rights of public employees. Had they been receiving their paychecks from the government, these workers would have had a strong claim under the First Amendment to protection against reprisals of this sort; their speech would have been recognized as involving matters of grave public concern, and thus as standing at the core of freedom of speech. ${ }^{4}$ For private sector employees, however, the controlling section 7 doctrine leads to opposite conclusions. What conception of work and of workers underlies this restriction on employee rights? Can it be one that comports with the language and policies of the NLRA?

Section 7 of the NLRA, enacted in 1935, gives to most private sector employees the right to engage in "concerted activities for the purpose of ... mutual aid or protection. ${ }^{n 5}$ Central among the activities covered by section 7 are union organizing and strikes to improve working conditions, but section 7 also protects employee protest and advocacy unrelated to traditional union activity. ${ }^{6}$ As such it affords to private sector employees some of the same protections that the First Amendment was later construed to confer on public employees. ${ }^{7}$ Together these two large bodies of federal

4 See infra text accompanying notes 42-53.

529 U.S.C. $\$ 157$ (1988); see supra note 2.

${ }^{6}$ See generally Charles J. Morris, NLRB Protection in the Nonunion Workplace: $A$ Glimpse at a General Theory of Section 7 Conduct, 137 U. PA. L. REV. 1673 (1989) (putting forward a general formula for distinguishing conduct the NLRB must protect under this language from that it which it may, but need not, protect).

${ }^{7}$ See, e.g., Rankin v. McPherson, 483 U.S. 378 (1987) (holding that a public employee may not be discharged for statements made in connection with a matter of public concern); Connick v. Myers, 461 U.S. 138 (1983) (same); Pickering v. Board of Educ., 391 U.S. 563 (1968) (same). For a sampling of recent commentary on the public employee speech doctrine, see Matthew W. Finkin, Intramural Speech, Academic Freedom, and the First Amendment, 66 TEX. L. REV. 1323 (1988); Richard M. Fischl, Labor, Management, and the First Amendment: Whose Rights Are These, Anyway?, 10 CARDOZO L. REV. 729 (1989); Risa L. Lieberwitz, Freedom of Speech in Public Sector Employment: The Deconstitutionalization of the Public Sector Workplace, 19 U.C. DAVIS L. Rev. 597 (1986); Toni M. Massaro, Significant Silences: Freedom of Speech in the 
law-section 7 of the NLRA and the public employee speech doctrine under the First Amendment-extend to most of this country's employees rights to discuss and protest matters of concern to them free from retaliation by their employers. ${ }^{8}$ Both require employers to tolerate employee speech that they will often find objectionable. And although the two doctrines are mutually exclusive in the scope of their coverage, ${ }^{9}$ the kinship between them is undeniable. ${ }^{10}$ Indeed, there has been a seemingly inevitable

Public Sector Workplace, 61 S. CAL. L. REv. 1 (1987).

${ }^{8}$ These doctrines are not the sole source of protection for employee protesters. Thus, some public sector "whistleblowers" enjoy protection by federal statute. See Whistleblower Protection Act of 1989, Pub. L. No. 101-12, 103 Stat. 16 (codified in scattered sections of 5 U.S.C. and 22 U.S.C.); Civil Service Reform Act of 1978, Pub. L. No. 95-454, 92 Stat. 1111 (codified as amended in scattered sections of 5 U.S.C. and numerous other titles). Under the latter statute, federal employees also have the right to engage in certain forms of concerted activity, including collective bargaining, but not the right to strike. See 5 U.S.C. $\$ \S 7101-7135$ (1988). Many state and local employees enjoy comparable rights under public employee bargaining statutes that are generally modelled on the NLRA (except that most deny or limit the right to strike). See HarRY T. EDWARDS ET AL., Labor RELATIONS LAW IN THE PUblic SECTOR: CASES AND MATERIALS 153-54 (3d ed. 1985). In addition, civil service laws, which generally require some cause for discharge and provide for hearings on the issue, offer some protection to public employees against retaliatory discharge. Finally, the Due Process Clause of the Fifth and Fourteenth Amendments protects many public employees against arbitrary discharge. See Cleveland Bd. of Educ. v. Loudermill, 470 U.S. 532, $541-43$ (1985).

Similarly, $\$ 7$ is not the sole source of protection for private sector employee protesters. Most states have recognized, at least in some (limited) circumstances, a "public policy exception" to the presumption that employment is "at will." This exception makes discharge actionable where it is deemed to violate public policy, as where an employee is discharged for exposing or refusing to engage in unlawful conduct. Such actions are supplemented by an increasing number of state "whistleblower" statutes. See MATTHEW W. Finkin ET AL., LeGAl Protection For THE INDIVIDUAL EMPLOYEE 284-86 (1989); Massaro, supra note 7, at 17-20. Still, as a practical matter, state remedies for wrongful discharge are less than readily available. See PaUl C. WeILer, Governing the WorkPLACE: THE Future of LABOR and EMPLOYMENT LAW 81-82 (1990); Clyde W. Summers, Individual Protection Against Unjust Dismissal: Time for a Statute, 62 VA. L. Rev. 481, $487-88$ (1976); Note, Protecting Employees at Will Against Wrongful Discharge: The Public Policy Exception, 96 HARV. L. REv. 1931, 1937-42 (1983); see also infra text accompanying notes 251-59.

${ }^{9}$ The vast majority of private sector employees in this country, though not protected by the First Amendment, are covered by the NLRA and its strictures against retaliatory discharge; the chief exclusions are those for agricultural employees and employees covered by the Railway Labor Act, 45 U.S.C. \$\$ 151-188 (1988). See 29 U.S.C. \$ 152(2)-(3) (1988) (defining "employer" and "employee" for purposes of the NLRA). Public employees, by contrast, while protected by the First Amendment, are excluded from the NLRA's coverage. Id.

${ }^{10}$ Some commentators have applauded the influence of public employee speech principles on $\$ 7$ rights. See Staughton Lynd, Employee Speech in the Private and Public Workplace: Two Doctrines or One?, 1 INDUS. REL. L.J. 711 (1977); cf. Clyde W. 
convergence between the two with respect to a variety of issues. ${ }^{11}$ But as to the crucial issue of subject matter-the topics on which employee expression is protected-these two bodies of law have developed in strikingly different directions. ${ }^{12}$ Section 7 has been interpreted to protect only employee speech relating to terms and conditions of employment, ${ }^{13}$ while the First Amendment now protects public employees only when they speak on "matters of public concern."14 To a great extent, then, the kinds of protests that in the private sector are covered by section 7-those concerning the terms and conditions of employment-are unprotected by the First Amendment in the public sector. Conversely, the protests covered by the First Amendment-those on "matters of public concern"-lie beyond the scope of section 7 in the private sector. ${ }^{15}$

This largely unexplored aspect of section 7 doctrine is the subject of Part I of this Article. In Part II, I launch my critique of the subject-matter limits of section 7 of the NLRA. Section 7 is meant to protect employees who act together to advance the

Summers, The Privatization of Personal Freedoms and Enrichment of Democracy: Some Lessons From Labor Law, 1986 U. ILL. L. REV. 689, 697 (noting that with the Wagner Act, "Congress brought the First Amendment to private employment"). At least one scholar, however, is not so sanguine about the desirability of this kinship. See Lieberwitz, supra note 7. Lieberwitz decries the increasing deference to hierarchical modes of workplace management, long pervasive in the interpretation of the NLRA, in the doctrine of public employee speech. Id. at 638-66.

${ }^{11}$ See Lynd, supra note 10, at 754 (describing the convergence between the two doctrines as "remarkable"). For example, in Mt. Healthy City Sch. Dist. Bd. of Educ. v. Doyle, 429 U.S. 274 (1977), the Court held that a discharge of a public employee violates the First Amendment where it is partly motivated by the employee's having engaged in protected speech, unless the employer can prove that it would have fired the individual even absent the speech. In Wright Line, 251 N.L.R.B. 1083 (1980), enforced, 662 F.2d 899 (1st Cir. 1981), cert. denied, 455 U.S. 989 (1982), the National Labor Relations Board adopted a very similar test, modelled on $M t$. Healthy, for proof of unlawful discrimination under $\$ 8(a)(3)$ of the NLRA, 29 U.S.C. $\$ 158(a)(3)$ (1988). The Board's Wright Line test was upheld by the Supreme Court in NLRB v. Transportation Mgmt. Corp., 462 U.S. 393 (1983).

12 Professor Richard Michael Fischl noted but did not focus on this difference in his recent commentary. See Fischl, supra note 7, at 740; see also ARCHIBALD COX ET AL., CASES AND MATERIALS ON LABOR LAW 545-46 (1991) (noting the same contrast). Lynd notes in passing that $\S 7$, unlike the First Amendment, protected only speech "connected with a labor dispute." Lynd, supra note 10, at 712 n.3. The significance of that limitation, and its contrast with First Amendment doctrine, was not fully apparent until the Court's decision in Connick v. Myers, 461 U.S. 138 (1983), which all but banished public-employee speech arising out of a job-related dispute from the First Amendment. See infra text accompanying notes 42-53.

${ }^{13}$ See infra text accompanying notes $20-41$.

14 See infra text accompanying notes $42-55$.

${ }^{15}$ See infra text accompanying notes 56-97. 
interests they share with their co-workers. The notion that employees' shared interests extend only to their wages and working conditions is compelled neither by the language nor by the intent of section 7, and should be rejected. It is based on a partial and increasingly outdated vision of the meaning of work in this society. Abundant evidence demonstrates the existence of profound employee concern over such matters as the safety and quality of the product or service they provide. Such concerns emerge from and affect the work experience and well-being of employees just as do concerns about wages and material working conditions. ${ }^{16}$ Employee interests in safety and quality are shared, of course, by consumers and the public, but this should only strengthen their claim to protection under section 7 , for private employee speech on matters of concern to the public, much like public employee speech on such matters, provides valuable information that enriches public discourse. This public interest underscores the need to recognize a broader range of employee concerns under the Act. ${ }^{17}$

In Part III, I advance an alternative interpretation of "mutual aid or protection" under section 7 and explore its probable ramifications. I make this proposal less with an eye to its adoption than to sharpen the focus of my criticism of the prevailing conception of employee interests under section 7 . I argue that where employees manifest their shared concern over a given issue by engaging in "concerted activity," this fact is a truer guide to the interests of employees than is an arbitrary delimitation like the one imposed by current section 7 doctrine. From this perspective it is clear that employees have a legitimate interest not only in the terms and conditions of their employment, but in the effect their employer's product or conduct has on customers, consumers, patients, clients, and the public at large. The scope of employee "mutual aid or protection" under section 7 thus should be expanded to accommodate the real range of employee concerns. This proposal might seem to portend a dramatic escalation in the workplace protest that employers must tolerate. But its probable consequences turn out, on closer examination, to be more modest, for they are limited by various restrictions on employee rights under section 7 , both in the law and in the realities of the workplace. ${ }^{18}$

${ }^{16}$ See infra text accompanying notes 123-65.

${ }^{17}$ See infra text accompanying notes 166-89.

${ }^{18}$ See infra text accompanying notes 214-33. 
The more serious obstacles to my proposal lie deeply embedded in the employment relationship; it is to these difficulties that I turn in Part IV. The narrow reading of section 7 under current law reflects not just a crimped view of the interests of employees and the public, but also an expansive solicitude for the competing interests of employers-in particular, the employer's interest in the loyalty of its employees, and, more broadly, in managerial prerogatives that are thought to be threatened by employee meddling in matters apart from the immediate employment relationship. Solicitude for these employer "rights" is all-too-well established at present, but I argue that they have a tenuous standing under the NLRA in light of the plain intention of Congress to limit those rights dramatically with the passage of the Wagner Act in 1935. Ultimately, they do not provide particularly compelling grounds for preferring one interpretation of section 7 to another, and should give way to the interests of employees in speaking out on matters of concern to them at the workplace, and to the public interest in broader disclosure of information about the operations of important economic actors. ${ }^{19}$

Current section 7 doctrine designates for employees a limited sphere in which economic self-interest reigns. It reflects an impoverished understanding of the meaning of work in our lives and penalizes those who develop and express genuine concerns about the many ways in which the enterprises for which they work affect the communities in which they live. The expansive vision embodied in section 7 calls for a more generous conception of employee interests and employee rights.

\section{Through the LOOKING GLASS: ConTrasting Protections UNDER SECTION 7 AND THE FIRST AMENDMENT}

The contours of section 7 doctrine appear in sharp relief when juxtaposed against the protections the First Amendment affords public employee protest and advocacy. Both doctrines implicitly posit a spectrum running from purely self-interested, work-related concerns to purely political expression. Both draw a line at much the same point along that spectrum, distinguishing between speech of concern to third parties and the general public and speech on traditional workplace grievances. But this distinction has diametrically opposite implications for the two groups of employees: a

${ }^{19}$ See infra text accompanying notes 260-302. 
work-related grievance is the key to protection under section 7; it may sound the death knell of the public employee's claim under the First Amendment.

\section{A. A First Look: Eastex, Jefferson Standard and Connick v. Myers}

The "mutual aid or protection" clause of section 7 extends the scope of protected advocacy beyond that which pertains to actual "terms and conditions of employment," 20 but not by much. This is evidenced by the Supreme Court's decision in Eastex, Inc. $v$. NLRB. ${ }^{21}$ In Eastex the Court held that section 7 protected employees' distribution of leaflets discussing the presidential veto of an increase in the federal minimum wage and commenting on a proposed state constitutional amendment enshrining the "right-towork" principle..2 The newsletter exhorted members to "defeat our enemies and elect our friends. ${ }^{23}$ The Court framed the issue as whether the concerted activity bore a sufficiently "immediate relationship to employees' interests as employees" to pass muster under section $7,{ }^{24}$ or whether the "relationship [was] so attenuated that [the] activity cannot fairly be deemed to come within the 'mutual aid or protection' clause." 25

The Court concluded that the matters discussed in the newsletter bore on the employees' terms and conditions of employment significantly enough to uphold the Board's decision in their favor. The proposed constitutionalization of the existing statutory "right to work" provision, the Court suggested, "could affect employees adversely "by weakening Unions and improving the edge business

${ }^{20}$ That phrase is used elsewhere in the Act to designate those subjects regarding which an employer is statutorily required to bargain with the designated representative of its employees. See NLRA $\$ 8(d), 29$ U.S.C. $\$ 158(d)$ (1988). The broader scope of $\S 7$ is treated in Julius G. Getman, The Protection of Economic Pressure by Section 7 of The National Labor Relations Act, 115 U. PA. L. Rev. 1195, 1218-22 (1967).

21437 U.S. 556 (1978). The Eastex decision is the subject of insightful analyses by Professors Richard Michael Fischl and Alan Hyde. See Richard M. Fischl, Self, Others, and Section 7: Mutualism and Protected Protest Activities Under the National Labor Relations Act, 89 CoLUM. L. REv. 789, 796-800 (1989); Alan Hyde, Economic Labor Law v. Political Labor Relations: Dilemmas for Liberal Legalism, 60 TEX. L. REv. 1, 7-11 (1981).

\footnotetext{
${ }^{22}$ Eastex, 437 U.S. at 569-70.

${ }^{23} \mathrm{Id}$. at 559-60.

24 Id. at 56 ?.

${ }^{25} \mathrm{Id}$. at 568 .
} 
has at the bargaining table." ${ }^{26}$ The minimum wage issue was more problematic for the Court, for on its face the newsletter merely appealed to the employees' solidarity with lower-paid workers, which, standing alone, would probably not have qualified for section 7 protection. ${ }^{27}$ But the Court agreed with the Board that the employees, in distributing the newsletter, were likely motivated by "the widely recognized impact that a rise in the minimum wage may have on the level of negotiated wages generally"; moreover, "concern by [these] employees for the plight of other employees might gain support for them at some future time when they might have a dispute with their employer."28

What had appeared to be a solidaristic appeal on behalf of the principles of the labor movement was transformed in Eastex into a calculated appeal to the pocketbook-and in this guise was protected. ${ }^{29}$ Eastex demonstrates that some speech on matters beyond the actual terms and conditions of employment-even matters over which the employer has no direct control-may gain section 7 protection, but only if it can be linked to a traditional self-interested economic objective. In the absence of such an objective, section 7 does not protect even employee protests aimed at the practices of their own employer.

Consider NLRB v. Local Union 1229, IBEW, ${ }^{30}$ the Jefferson Standard case. There the Supreme Court held that section 7 did not protect a group of broadcast technicians fired for distributing leaflets critical of the quality of television service their employer provided to the public. ${ }^{31}$ Their leaflet read in part:

\section{IS CHARLOTTE A SECOND-CLASS CITY?}

You might think so from the kind of Television programs being presented by the Jefferson Standard Broadcasting Co. over WBTV .... Did you know that all the programs presented over WBTV are on film and may be from one day to five years old. There are no local programs presented by WBTV. You cannot receive the local baseball games, football games or other local events because WBTV does not have the proper equipment to make these pickups.... Why doesn't the Jefferson Standard

${ }^{26} I d$. at 569 (quoting the newsletter at issue).

27 See id.

${ }^{28}$ Id. at 569-70 (quoting Eastex, Inc., 215 N.L.R.B. 271, 274 (1974) (quoting

General Elec. Co., 169 N.L.R.B. 1101, 1103 (1968))).

${ }^{29}$ See Fischl, supra note 21, at 796-98.

so 346 U.S. 464 (1953).

${ }^{31}$ See id. at 477 . 
Broadcasting Company purchase the needed equipment to bring you the same type of programs enjoyed by other leading American cities?. Could it be that they consider Charlotte a second-class community and only entitled to the pictures now being presented to them?

\section{WBT TECFINICIANS 32}

The Court characterized the leaflets, which apparently contained no factual misrepresentations, ${ }^{33}$ as a "sharp, public, disparaging attack upon the quality of the company's product and its business policies,"34 and held that the employees had engaged in "such detrimental disloyalty" as to lose section 7 protection. ${ }^{35}$

Notwithstanding the Court's harsh characterization, it is clear that neither the tone of the leaflet nor the directness with which it targeted the employer accounts for the holding in the case. "Sharp, public, disparaging attack[s]" on an employer are hardly uncommon in labor disputes; yet they are protected by section $7 .^{36}$ Nor does the result follow from the fact, found by the Board and credited by the Court, that the true purpose of the radio technicians' attack on their employer's product, undisclosed in the leaflets, was to gain an advantage in ongoing collective bargaining negotiations. ${ }^{37}$ On the contrary, this traditional economic purpose might have put the employees on stronger ground had they disclosed it in their leaflets. ${ }^{38}$ In fact, the Court left no doubt that the employees' case

32 Id. at 468.

${ }^{33}$ See id. at 472 .

${ }^{34} I d$. at 471.

${ }^{35} I d$. at 472.

${ }^{36}$ See, e.g., Linn v. United Plant Guard Workers Local 114, 383 U.S. 53, 60-61 (1966) (statements that may "defame one of the parties to the dispute" are protected); NLRB v. Container Corp. of America, 649 F.2d 1213, 1214-15 (6th Cir. 1981) (implication that manager was a slave driver and treated employees like a chain gang" protected); Great Lakes Steel v. NLRB, 625 F.2d 131, 132 (6th Cir. 1980) (accusation that employer had engaged in "murder for profit" protected); New York Univ. Medical Ctr., 261 N.L.R.B. 822 (1982) (accusation that employer's guards used "fascist gestapo" tactics protected). See generally Getman, supra note 20, at 1239 (recognizing that "bitter and intense" attacks against the employer for his labor policies are permitted under the Act); John B. Lewis et al., Defamation and the Workplace: A Survey of the Law and Proposals for Reform, 54 Mo. L. REV. 797, 837-42 (1989) (describing treatment of defamation in labor disputes).

${ }^{37}$ See Jefferson Standard, 346 U.S. at 476-77.

38 The Court emphasized the employees' failure to disclose their involvement in a labor dispute, id. at 476-77, and, following the Board, reserved judgment on "whether the disparagement of product involved here would have justified the employer in discharging the employees responsible for it, had it been uttered in the context of a conventional appeal for support of the union in the labor dispute." Id. 
would have been further weakened by the lack of an underlying economic purpose-that is, had they been motivated solely by a sincere concern for the quality of the product they helped put out:

Assuming that there had been no pending labor controversy, the conduct of the [employees] ... unquestionably would have provided adequate cause for their disciplinary discharge .... Their attack related itself to no labor practice of the company. It made no reference to wages, hours or working conditions. The policies attacked were those of finance and public relations for which management, not technicians, must be responsible. ${ }^{39}$

Jefferson Standard thus rests squarely on a limited view of the legitimate interests of employees: concerted public criticism of the product or service provided by an employer does not itself advance the "mutual aid or protection" of workers; it is simply too remote from the employees' legitimate concerns regarding the terms and conditions of their own employment to be entitled to section 7 protection.

This view of Jefferson Standard supplements the conventional reading of the decision as condemning the tactical use of "product disparagement" to achieve traditional collective bargaining objectives: activity of this kind, while it is literally "concerted activity for mutual aid or protection" and is not illegal, is nonetheless unprotected because it is held to be an "indefensible" and "disloyal" tactic. ${ }^{40}$ Jefferson Standard is thus read, entirely correctly, as an "outside" limitation on activity that is literally within the terms of section 7. But it is clear that the decision necessarily rests as well on an "internal" limitation on the meaning of section 7: concerns about the product (or other aspects of the employer's policies not directly relating to terms and conditions of employment) are not themselves the proper subject of concerted activity by employees

at 477 (quoting Jefferson Standard Broadcasting Co., 94 N.L.R.B. 507, 1512 n.18 (1951)). Subsequent cases have tended to find criticism of the employer's product protected if it is not excessively disparaging in tone and is made in the context of an attempt to improve working conditions. See infra text accompanying notes 68-81.

39346 U.S. at 476 (emphasis added).

40 See, e.g., JAMES B. ATLESON, VALUES AND AsSUMPTIONS IN AMERICAN LABOR LAW 84-85 (1983); COX ET AL., supra note 12, at 546-50 (providing numerous examples of unprotected concerted activities). 
because they are irrelevant to the goal of "mutual aid or protection." 41

The First Amendment analysis of this case, under modern public employee speech doctrine, would have been quite different. Had the Jefferson Standard technicians been employed by a government agency, and fired for publicly criticizing the quality of the agency's services, they very likely would have been entitled to reinstatement. Under the Supreme Court's decision in Connick v. Myers, ${ }^{42}$ their protest would most likely have been deemed speech on a "matter of public concern," and thus protected against employer retaliation, precisely because it was unrelated to the terms and conditions of the protesters' own employment. ${ }^{43}$

Connick v. Myers illustrates the application of the public employee speech doctrine. Sheila Myers, an assistant district attorney in New Orleans, was informed in 1980 that she was to be transferred to $\dot{a}$ different section of the criminal court. She objected and raised with a supervisor a "number of other office matters" relating to morale and fairness in the office. ${ }^{44}$ When her supervisor claimed that her concerns were not shared by her coworkers, Myers prepared and distributed a questionnaire "soliciting the views of her fellow staff members concerning office transfer policy, office morale, the need for a grievance committee, the level of confidence in supervisors, and whether employees felt pressured to work in political campaigns." 45 Fearing that Myers was "creat-

41 See ATLESON, supra note 40, at 85 ("It is also surprising, but perhaps revealing, that the Board would feel that quality of equipment and programming would be irrelevant to the station's technicians.").

42461 U.S. 138 (1983).

43 As I will show, some courts might withdraw First Amendment protection if the evidence showed an underlying purpose of advancing economic self-interest, whether disclosed or not. See infra text accompanying notes 57-66. At least absent such a purpose, however, the criticism would quite certainly be deemed a "matter of public concern." See, e.g., Greenberg v. Kmetko, 811 F.2d 1057, 1060 (7th Cir. 1987) (holding that a social worker's criticism of his agency's handling of cases was speech on a matter of public concern), affd in relevant part, 840 F.2d 467, 474 (7th Cir. 1988) (en banc); Czurlanis v. Albanese, 721 F.2d 98, 104 (3d Cir. 1983) (finding that public allegations of inefficiency, falsification of reports, and performance of unnecessary repairs involved matters of public concern, in part because the employee did not air any grievances regarding his own working conditions). For a survey of lower court decisions applying Connick, see Stephen Allred, From Connick to Confusion: The Struggle to Define Speech on Matters of Public Concern, 64 IND. L.J. 43, 55-68 (1988).

${ }^{44}$ See Connick, 461 U.S. at 140-41.

${ }^{45} \mathrm{Id}$. 
ing a 'mini-insurrection' within the office," the district attorney discharged her. ${ }^{46}$

In upholding her discharge against a First Amendment challenge, the Supreme Court held that, with the sole exception of the question relating to work in political campaigns, the questionnaire did not raise "matters of public concern." 47 According to the Court, "Myers did not seek to inform the public that the District Attorney's Office was not discharging its governmental responsibilities in the investigation and prosecution of criminal cases. Nor did Myers seek to bring to light actual or potential wrongdoing or breach of public trust .... ${ }^{\text {48 }}$ Apart from the one question regarding political pressures, then, her questions were mere extensions of Myers's dispute over her transfer and not worthy of protection under the First Amendment. ${ }^{49}$ There is no doubt that the entirety of Myers's questionnaire was within the general ambit of freedom of expression; that is, it was not within "one of the narrow and well-defined classes of expression" such as obscenity that is excluded from the First Amendment altogether. ${ }^{50}$ But Connick held that a public employee's discharge is subject to First Amendment scrutiny only when she speaks on a "matter of public concern." ${ }^{51}$ In the majority's view, most of Myers's speech failed to meet this new threshold test.

Ironically, a public employee discharged for distributing leaflets like those at issue in Jefferson Standard would have little difficulty surmounting the hurdle posed by the public concern test in Connick. ${ }^{52}$ But to sharpen the irony, it is also the case that, had Sheila Myers been a private employee covered by the NLRA, her effort to ascertain whether her fellow employees shared her
${ }^{46} I d$.
${ }^{47}$ Id. at $147-49$.
${ }^{48} I d$. at 148 .

49 Id. Regarding the question relating to pressure to work on campaigns, the Court held that Myers' interest in speaking freely on this matter of "limited" public concern was outweighed by the government interest in "effective and efficient fulfillment of its responsibilities, "id. at 150, despite the absence of evidence that her actions disrupted operations or affected her performance in any way. See id. at 151, 154.

${ }^{50} \mathrm{Id}$. at 147.

51 Id. at 146. For my critique of the "public concern" test announced in Connick (and since incorporated into the First Amendment law governing defamation actions), see Cynthia L. Estlund, Speech on Matters of Public Concern: The Perils of an Emerging First Amendment Category, 59 GEO. WASH. L. REV. 1 (1990).

52 See supra text accompanying notes $30-41$. 
concerns about morale, the lack of a grievance procedure, and the fairness of the transfer arrangements would almost certainly have been protected by section 7 of the Act, ${ }^{53}$ entitling her in all likelihood to reinstatement and back pay. Her objective would certainly have been for "mutual aid or protection," conduct would very likely have met the definition of "concerted activity. ${ }^{\mathrm{N5}}$ Myers's speech would have fallen within the realm of statutorily protected workplace protest under section 7 precisely because it was grounded in ordinary workplace concerns.

\section{B. A Closer Look at the Contrast}

"Speech on matters of public concern" and "speech on terms and conditions of employment" are not, of course, mutually exclusive categories. A good deal of employee speech is, to some degree, both. ${ }^{56}$. What bears emphasis is that in determining whether such speech is eligible for protection, the two elements have precisely opposite consequences under section 7 doctrine and First Amendment doctrine respectively.

This point was evident in Connick itself. On the one hand, the Court acknowledged that Sheila Myers's questionnaire dealt with issues of potential concern to the public, inasmuch as "discipline and morale in the workplace are related to an agency's efficient performance of its duties." 57 Yet the Court went on to conclude that 'the focus of Myers' questions is not to evaluate the performance of the office but rather to gather ammunition for another round of controversy with her superiors. These questions reflect

53 She would not have been protected if she was acting in violation of a valid nosolicitation rule limiting such activity to nonwork time in nonworking areas. See Republic Aviation Corp. v. NLRB, 324 U.S. 793, 803 n.10 (1945).

54 The subject matter of Myers' questionnaire is clearly pertinent to terms and conditions of employment, and thus within the legitimate realm of employee protest under $\$ 7$.

55 Generally speaking, a single employee's attempt to solicit the involvement of fellow employees on employment-related grievances is protected under $\$ 7$. See NLRB v. City Disposal Systems, Inc., 465 U.S. 822, 831 (1984); infra notes 197-198 and accompanying text. Certainly Myers' supervisors saw her actions as directed toward group action: they fired her for attempting to "creat [e] a 'mini-insurrection." Connick, 461 U.S. at 141.

56 See James G. Pope, Labor-Community Coalitions and Boycotts: The Old Labor Law, the New Unionism, and the Living Constitution, 69 TEX. L. REv. 889, 902-04 (1991) (noting the coincidence of traditional labor and community objectives in many coalition campaigns).

57 Connick, 461 U.S. at 148. 
one employee's dissatisfaction with a transfer and an attempt to turn that displeasure into a cause célèbre. ${ }^{n 58}$ The presence of a selfish motive behind Myers's questionnaire thus tainted the message it communicated and doomed her First Amendment claim. ${ }^{59}$

The lower courts have seized upon this device as a way to clear many public employee speech cases from their dockets. ${ }^{60}$ The courts have permitted the silencing of public employee complaints about educational quality, ${ }^{61}$ corporal punishment of children in their care, ${ }^{62}$ treatment of patients in public institutions, ${ }^{63}$ and use of public funds, ${ }^{64}$ in each case finding that the complaints were rooted in personal work-related grievances. The presence of such a grievance does not automatically result in a loss of protection where matters otherwise of concern to the public are at issue. ${ }^{65}$ There is no doubt, however, that the presence of a self-interested, employment-related grievance now poses a significant problem for

${ }^{58}$ Id.

${ }^{59}$ See id.

60 The amenability of the public concern requirement-which the Court in Connick characterized as an issue of law, not of fact, see Connick, 461 U.S. at 148 n.7-to summary judgment procedures may have been among its chief attractions to a Court majority seeking to free public employers from the threat of protracted litigation over many public employee speech cases. See Estlund, supra note 51, at 53 n.287.

61 See, e.g., Landrum v. Eastern Ky. Univ., 578 F. Supp. 241, 246-47 (E.D. Ky. 1984) (finding that a professor's criticism of the school administration on matters of academic policy was properly characterized as a personal dispute); Ballard v. Blount, 581 F. Supp. 160, 163-64 (N.D. Ga. 1983) (holding that a faculty member's complaints about his salary, the assignment of freshman English courses, and the content and procedures used in reviewing his course syllabus did not touch on matters of public concern), affd, 734 F.2d 1480 (11 th Cir.), cert. denied, 469 U.S. 1086 (1984); Mahaffey v. Kansas Bd. of Regents, 562 F. Supp. 887,890 (D. Kan. 1983) (characterizing the points of departmental policy criticized by a faculty member as "quintessentially" of personal rather than public concern).

62 See Moore v. Mississippi Valley St. Univ., 871 F.2d 545, 551 (5th Cir. 1989) (holding that day care center employees' complaints about corporal punishment of children "perhaps ris[e] above th[e] purely personal level," but are not of public concern because they are motivated by the "personal grievance[s] of the employees").

${ }^{63}$ See Smith v. Gleburne County Hosp., 870 F.2d 1375, 1382 (8th Cir. 1989) (explaining that plaintiff's criticism of the quality of patient care and the incompetence of hospital administrators was left unprotected when it took the form of "caustic personal attacks").

${ }^{64}$ See Berg v. Hunter, 854 F.2d 238, 242 (7th Cir. 1988) (noting that "[a]lthough matters of sexual harassment [and] the misappropriation of college property . . . may relate to [the college's] efficient performance," plaintiff's charges did not raise "broader issues of public school administration unrelated to his personal disputes").

${ }^{65}$ See generally Allred, supra note 43 , at 44 (reviewing cases). 
the public-employee protester seeking protection against retaliation under the First Amendment. ${ }^{66}$

And yet the same link between protest and the terms and conditions of one's own employment, so damning to the public employee under Connick, is an indispensable prerequisite to the private employee's claim to section 7 protection. ${ }^{67}$ Indeed, if the link is sufficiently apparent, a good deal of comment on "matters of public concern" can be brought under the aegis of section $7 .{ }^{68}$ This means that organized, well-advised groups of employees can gain protection for what may seem to be straightforward "product disparagement," notwithstanding Jefferson Standard. ${ }^{69}$ Thus, aircraft mechanics who publicly questioned the safety of airline maintenance procedures, ${ }^{70}$ ambulance drivers who criticized the safety of their vehicles and their own readiness, ${ }^{71}$ nurses who complained about the level of medical care in a medical facility, ${ }^{72}$ and reporters who expressed dissatisfaction with the quality of their newspaper ${ }^{73}$ have all managed to find protection under section 7 . In each case the employees were able to avoid the strictures of Jefferson Standard simply by making it clear that their criticisms arose out of ongoing labor disputes of a traditional sort. ${ }^{74}$

${ }^{66}$ See generally Estlund, supra note 51, at 36-38 (explaining that, under Connick, otherwise protected speech may be "demoted" if it arises in the context of a workplace grievance).

${ }^{67}$ Cf. Fischl, supra note 21. Professor Fischl's focus in his very illuminating article-employee activity in support of other workers in connection with the terms of the latter's employment-is different from mine. Nonetheless, my thinking profited greatly from his chronicle and critique of the judicial search for self-interest in apparently solidaristic activities.

${ }^{68}$ Much of the activity described by Pope, supra note 56 , is of the sort that could run afoul of limitations on $\$ 7$ protection but that could also, and often does, emphasize the effect of the criticized practices on employees.

${ }^{69}$ See infra text accompanying notes 125-51.

${ }^{70}$ See Allied Aviation Serv. Co., 248 N.L.R.B. 229, enforced, 636 F.2d 1210 (3d Cir. 1980).

${ }^{71}$ See SAS Ambulance Serv., Inc., 255 N.L.R.B. 286 (1981).

72 See NLRB v. Mount .Desert Island Hosp., 695 F.2d 634 (1st Cir. 1982); Community Hosp. of Roanoke Valley, Inc. v. NLRB, 538 F.2d 607 (4th Cir. 1976).

${ }^{73}$ See Sierra Publishing Co. v. NLRB; 889 F.2d 210 (9th Cir. 1989).

74 For more examples, see NLRB v. Greyhound Lines, Inc., 660 F.2d 354, 356-57 (8th Cir. 1981) (holding that a press release announcing bus drivers' intent to drive 55 m.p.h. on Labor Day, and predicting delays, was protected because the plan was expressly linked to contract grievances); Roadmaster Corp., 288 N.L.R.B. 1195 (1988) (holding that union publicity concerning the alleged mislabeling of imported bicycles to make them appear to have been domestically produced was protected). The chief rationale for the generally more favorable treatment of product criticism that is explicitly linked to a labor dispute seems to be that "third parties who receive appeals 
The real bite of Jefferson Standard is felt chiefly by employees, particularly unorganized employees, with unselfish and entirely genuine concerns that do not happen to involve traditional labor objectives such as wages, hours, or job security. In such cases, the courts are sometimes quite "generous" in their assessment of apparently public-spirited actions-generous, that is, in the perverse sense of straining to find a selfish, and therefore protected, motive behind seemingly selfless behavior. In Misericordia Hospital Medical Center $v . N L R B,{ }^{75}$ for example, the Board ordered the reinstatement of a hospital nurse fired for preparing, together with a group of her co-workers, a report to an accreditation body that was critical of hospital policies. The report focused on problems involving inadequate staffing and facilities, emergency room and admissions policies, and unsanitary conditions at the hospital, and was concerned almost exclusively with the way these problems were affecting patient care. But it also contained some minor and incidental references to staff working conditions; on this tenuous ground, the nurse's activity was held to be within the protection of section $7 .^{76}$ Misericordia is only one of a number of decisions that appear to exaggerate, or even manufacture, the element of selfinterest that brings section 7 into play. ${ }^{77}$

for support in a labor dispute will filter the information critically so long as they are aware that it is generated out of that context." Sierra Publishing, 889 F.2d at 217.

Some decisions, however, have applied the Jefferson Standard doctrine to bar "disparaging" or otherwise damaging comments even where they directly concerned labor relations matters. See, e.g., NLRB v. Red Top, Inc., 455 F.2d 721, 727 (8th Cir. 1972) (holding that a threat to take work-related grievances to an employer's customer was unprotected "disloyalty"). This approach has been criticized, however, as "contrary to the overwhelming weight of authority." Sierra Publishing, 889 F.2d at 219; $c f$. NLRB v. Pincus Bros., Inc., 620 F.2d 367, 376-77 (3d Cir. 1980) (deferring to an arbitrator's denial of reinstatement on the grounds that the employee's distribution of a leaflet critical of her employer and union with regard to wages and other labor relations matters was "arguably unprotected" disloyalty).

75246 N.L.R.B. 351 (1979), enforced, 623 F.2d 808 (2d Cir. 1980).

${ }^{76}$ See id. at 356 . The Board also relied on the nurses' professional obligation "to act to improve the standards of nursing care and to join with others to meet the public's health needs." Id. This argument, which would greatly expand the scope of $\S 7$ protections for many professionals, see infra text accompanying notes $127-33$, was relegated to a footnote by the reviewing court, see Misericordia, $623 \mathrm{~F} .2 \mathrm{~d}$ at $814 \mathrm{n.9}$, and has not appeared in other decisions. Cf. Cordura Publications, Inc., 280 N.L.R.B. 230,231 (1986) (relying on employees' desire to "increas[e] the professionalism of their jobs" in finding their actions protected by $\$ 7$ ).

${ }^{77}$ See, e.g., NLRB v. Oakes Mach. Corp., 897 F.2d 84, 89 (2d Cir. 1990) (holding that employees' protest to higher management over company president's diversion of resources to personal projects was protected because such diversion affected company profitability and thus employee compensation); Squier Distrib. Co. v. Local 
The pattern in these cases is similar to that which emerges, as Professor Richard Michael Fischl has shown, in cases involving employees disciplined for actions taken for the sake of solidarity with other workers, where there is little prospect for reciprocal gain. ${ }^{78}$ Thus, in Hendricks County Rural Electric Membership Corp. v. $N L R B,{ }^{79}$ for example, a secretary was fired for signing a petition on behalf of an employee who had recently been discharged after losing an arm in an on-the-job accident, rendering him unable to perform his previous duties. The petition decried the fact that "no one is willing to speak up or defend what is right if it might mean jeopardizing one's own self," and proclaimed that "other people do matter and Lloyd Hadley matters, to us and to many other people." 80 The Board reinstated the secretary, but only after overcoming the hurdle posed by the manifestly unselfish nature of the appeal by misconstruing the petition as motivated by the signatory employees' concern for their own job security. ${ }^{81}$ Here, too, there is a perverse sort of "generosity" in the factfinders' determination that apparently unselfish employee action was "really" motivated by considerations of self-interest.

7, Int'l Bhd. of Teamsters, 801 F.2d 238, 241 (6th Cir. 1986) (reinstating employees fired for reporting the embezzlement of company funds because "[ $t$ ]he employees' overriding concern was clearly for their job security, and not for the efficacy of managerial decisions"); Cordura Publications, 280 N.L.R.B. at 231-32 (holding that employees' letter to the chairman of the board was protected, despite its focus on management practices and the quality of the employer's product (automobile research), because such issues related to the poor treatment of employees); Dominican Sisters of Ontario, Inc., 264 N.L.R.B. 1205, 1205 n.2 (1982) (concluding that nurses' hiring of an attorney to address conditions in a hospital emergency room was protected because, "[w] hile the letter [soliciting the attorney's services] . . . was couched in terms of the concern [the nurses] had about the effect of inadequate staffing on patient care, it is implicit in the overall tenor of the letter that they were protesting their inability to carry out their duties as emergency room nurses because of alleged understaffing"); Professional Porter \& Window Cleaning Co., 263 N.L.R.B. 136, 138-39 (1982) (finding that maids' complaints to building management about the deteriorated condition of a building and the poor quality of cleaning materials were protected because such complaints were related to a dispute over conditions of employment).

${ }^{78}$ See Fischl, supra note 21, at 801.

79236 N.L.R.B. 1616 (1978), remanded on other grounds, 603 F.2d 25 (7th Cir. 1979), order reissued, 247 N.L.R.B. 498, enforcement denied, 627 F.2d 766 (7th Cir. 1980), rev'd with instructions to enforce, 454 U.S. 170 (1981). This case is discussed at length in Fischl, supra note 21, at 793-96.

${ }^{80}$ Hendricks County, 236 N.L.R.B. at 1620.

${ }^{81}$ See id. at 1620 (noting that the employees' uniting might "not only serve Hadley's interest but also their own as well”); Fischl, supra note 21, at 795-96. 
In many other cases, however, the decisionmakers have failed to locate the necessary element of self-interest and have accordingly denied protection. ${ }^{82}$ Thus, employees distributing leaflets on behalf of candidates "committed to working for the best interests of working men and women" found themselves on the wrong side of the line drawn in Eastex: the relationship between their politicking and the terms and conditions of their own employment was too "attenuated." 83

The most interesting cases are those in which employee criticism of an employer's own practices has fallen outside section 7 because it was too unselfish. ${ }^{84}$ One especially telling case involved counsel-

82 See Fischl, supra note 21, at 800-11. Professor Fischl explains that the courts (in contrast to the Board) may take this approach to employee refusals to cross a picket line where there is no realistic prospect of a reciprocal benefit to the noncrossing employee. See, e.g., NLRB v. Illinois Bell Tel. Co., 189 F.2d 124, 129 (7th Cir.), cert. denied, 342 U.S. 885 (1951) (denying protection to employee actions that "could have only been for the benefit and aid of those in a different bargaining unit, . . . [and] could have obtained nothing from [the employer] for [the protesters'] benefit"); $c f$. NLRB v. Browning-Ferris Indus., Chem. Servs., Inc., 700 F.2d 385, 389 (7th Cir. 1983) (denying reinstatement of truck drivers who refused to cross a picket line at the premises of their employer's customer).

${ }^{83}$ Local 174, UAW v. NLRB, 645 F.2d 1151, 1152, 1154 (D.C. Cir. 1981). The court so held even though the leaflet pointed to various governmental decisions in which the winning candidates might participate that would directly affect terms and conditions of employment. See id. at 1155. The $U A W$ case is targeted in Professor Alan Hyde's cogent critique of the distinction drawn in Eastex between political activity and "normal" economic activity for $\$ 7$ purposes. See Hyde, supra note 21; see also Eagle Elec. Mfg. Co., 114 L.R.R.M. (BNA) 1284, 1285 (1983) (advice memorandum of NLRB general counsel) (stating that employees' distribution of a leaflet in support of a Mexican student leader seeking asylum was too remote from employment-related issues and therefore unprotected); Tektronix, Inc., 100 L.R.R.M.(BNA) 1635 (1979) (advice memorandum of NLRB general counsel) (stating that distribution of a "highly political and inflammatory" leaflet aimed primarily at "Nazi[] [collaborators] and ... capitalists," and only to a minor extent at working conditions, was unprotected); $c f$. Ford Motor Co., 221 N.L.R.B. 663, 666 (1975) (holding, in a preEastex decision, that a newsletter urging the creation of an independent workers' party was "wholly political," and therefore unprotected), enforced, 546 F.2d 418 (3d Cir. 1976). See generally James B. Atleson, Reflections on Labor, Power and Society, 44 MD. L. REv. 841, 858-60 (1985) (describing and criticizing the exclusion of "political" speech from $\$ 7$ protection); Hyde, supra note 21 , at $9-17$ (to the same effect).

${ }^{84}$ In addition to the cases discussed below, see, e.g, Vincent v. Trend $W$. Technical Corp., 828 F.2d 563, 565-66 (9th Cir. 1987) (holding that employees' reporting of their employer's violation of the terms of a government contract was unprotected); NLRB v. Sheraton P.R. Corp., 651 F.2d 49, 52-53 (1st Cir. 1981) (holding that employees' letter protesting, among other things, management's failure to communicate with staff, the absence of innovation, and the lack of a marketing plan, was insufficiently related to "the direct concerns of the average worker," and therefore unprotected); University of S. Cal. Sec. Dep't., 99 L.R.R.M. (BNA) 1728, 1728-29 (1978) (advice memorandum of NLRB general counsel) (finding employees' 
ors at a home for emotionally disturbed children. ${ }^{85}$ The Board lauded the employees' "staunch dedication to the worthy occupation which they have chosen to pursue," and recognized that the employees "work[ed] in an environment and for a cause-the rehabilitation of troubled children-which must surely be steeped in currents of emotion seldom encountered in more ordinary employments. ${ }^{n 6}$ Yet because the employees were motivated by sincere concern for the quality of the care they were able to provide and the welfare of the children in their custody, their actions were held unprotected by section 7: they were not seeking to advance their interests "as employees." 87

In many other cases, employee altruism does not fare well under section 7. The Board denied protection to drug and alcohol counselors fired for publicly criticizing their employer's ethics and policies and their impact on adolescent patients. 88 Unfortunately for these employees, their criticisms "expressed a genuine concern for the residents' living conditions," and were "not directly related to the employees' working conditions. ${ }^{89}$ Nursing home employees fired for testifying about patient conditions and possible abuse were held unprotected because in so doing they had merely expressed their concern for the patients. ${ }^{90}$ Significantly, even internal criticism of this nature has been held unprotected because of its too-attenuated link to conditions of employment. ${ }^{91}$ Thus, hospital employees who had complained internally about their supervisor were denied protection because they "readily conceded they were concerned with ... the quality of care offered by the program and the welfare of the children [and that their] energies were not directed to improve their lot as employees. ${ }^{92}$

On balance, there are fewer reported cases involving the status under section 7 of employee criticism not directly related to terms and conditions of employment than one might expect. ${ }^{93}$ The

public criticism of campus safety unprotected because such complaints were not related to working conditions).

85 See Lutheran Social Serv., 250 N.L.R.B. 35 (1980).

${ }^{86} \mathrm{Id}$. at 35.

87 Id. at 42.

${ }^{88}$ See Damon House, Inc., 270 N.L.R.B. 143, 143 (1984).

${ }^{89} \mathrm{Id}$. at 143.

90 See Autumn Manor, Inc., 268 N.L.R.B. 239, 242 (1983).

91 See Good Samaritan Hosp. \& Health Ctr., 265 N.L.R.B. 618, 626 (1982).

$92 I d$. at 626.

93 The number of reported cases tells us little, however, about the prevalence of this sort of activity, or of employer retaliation against it, because of the many points 
explanation may lie, in part, in the exclusive power of the General Counsel to bring unfair labor practice complaints to the Board. ${ }^{94}$ Thus, in Daniel International, the case that provided the opening scenario for this Article, the General Counsel refused even to file a complaint on behalf of an employee fired for reporting allegedly improper construction practices at a nuclear facility. ${ }^{95}$ The employee's concern, lamentably, was for the future safety of the public, and not for his working conditions. ${ }^{96}$

The analysis in these section 7 cases is precisely the opposite of that which obtains in the public employee cases under Connick: if the drug counselors or the nursing home employees or the nuclear plant construction workers in these cases had been public employees claiming a right under the First Amendment, they probably would have prevailed. ${ }^{97}$ Their criticisms, untainted by any link to personal grievances about working conditions, would have satisfied

at which potential complaints of this sort may be screened out prior to the decision stage. First, only those employees who think to contact the NLRB with their problem will attempt to file an unfair labor practice (ULP) charge. Given the popular perception that the NLRB deals only with cases involving union activity-a perception shared by almost all of my entering labor law students and most of my law school colleagues-relatively few employees fired for protest outside the context of unionization even approach the Board. Those who do contact the Board often get no further than a telephone call, for only those whose inquiries are thought to fall within the Act by the NLRB officer answering the call-that is, those involving protest relating to terms and conditions of employment-are encouraged to file a charge. Moreover, only those charges that the Regional Director or General Counsel concludes are likely to prevail become the subject of formal complaints and are litigated before the Board. There is no appeal from the General Counsel's refusal to file a complaint on a ULP charge. See infra note 94 . An informal survey of several regional offices of the NLRB reveals that few calls of this nature come in and that such calls are simply turned away in the absence of a link to unionization or terms and conditions of employment.

${ }^{94}$ See NLRB v. United Food \& Commercial Workers Union, Local 23, 484 U.S. 112 , 118-19 (1987) (noting that a charging party has no recourse if the General Counsel declines to issue a ULP complaint).

${ }^{95}$ See Daniel Int'l, 104 L.R.R.M. (BNA) 1496, 1497 (1980). At that time, the fact that the employee was apparently acting alone was not a bar to $\$ 7$ protection. Under the since-abandoned Alleluia Cushion doctrine, an individual filing a safety complaint that would benefit her coworkers was deemed to be engaging in "concerted activity." See infra text accompanying notes 203-11. The express basis of the decision in Daniel International was that the employee's activity was not sufficiently related to terms and conditions of employment to bring it within $\$ 7$.

${ }^{96}$ See Daniel Int'l, 104 L.R.R.M. at 1497.

${ }^{97}$ Conversely, had the nurse in Misericordia been a public employee claiming First Amendment protection, she would have either failed to meet the public concern test because of the link to her own working conditions, or perhaps succeeded in spite of it. See supra text accompanying notes 75-77. 
the public concern test of Connick for the very same reasons for which their claims under section 7 were rejected.

\section{RECONCEIVING THE LEGITIMATE INTERESTS OF EMPLOYEES UNDER SECTION 7}

The denial of section 7 protection to employees who act for the sake of others-consumers, patients, clients, or the public generallyplainly pulls in the opposite direction from First Amendment jurisprudence. Moreover, there is something jarring about the privileging of self-interest over altruism in section 7 doctrine. ${ }^{98}$ But is there even so much as an interesting paradox here? After all, workplace issues, and particularly union organizing and collective bargaining over wages and other terms and conditions of employment, are plainly at the heart of the NLRA. ${ }^{99}$ Matters such as the quality of the employer's product or service may seem far afield from such issues. Conversely, political speech, or speech on "matters of public concern," is widely regarded as lying at the core of the First Amendment. ${ }^{100}$ Workplace grievances, even those of

${ }^{98}$ It is worth noting, however, that the privileged status of employee activity in pursuit of self-interest has a long history in labor jurisprudence. See infra text accompanying notes 110 -16.

99 See 29 U.S.C. $\$ 151$ (1988) (preamble to NLRA).

100 The view that the First Amendment protects only speech relevant to selfgovernment is closely associated with the scholarship of Alexander Meiklejohn. See, e.g., ALEXANDER MEIRLEJOHN, FREE SPEECH AND ITS RELATION TO SELF-GOVERNMENT 22-27 (1948); Alexander Meiklejohn, The First Amendment Is an Absolute, 1961 SuP. CT. REV. 245, 263 (asserting that "novels and dramas and paintings and poems" are relevant to self-government, and therefore protected). For modern variations on the Meiklejohn thesis, see Lillian R. BeVier, The First Amendment and Political Speech: An Inquiry Into the Substance and Limits of Principle, 30 STAN. L. REV. 299, 300-01 (1978), and Robert H. Bork, Neutral Principles and Some First Amendment Problems, 47 IND. L.J. 1,20 (1971). Professor Bork later publicly retreated from this position, calling it "speculative, tentative," and downright "dumb." Nomination of Judge Robert Bork to be Associate Justice of the Supreme Court of the United States: Hearings Before the Senate Judiciary Comm., 100th Cong., 1st Sess. 264 (1987) (statement of Robert Bork).

The view that speech relevant to self-government is of central constitutional significance continues to have a large following. See, e.g., JOHN H. ELY, DEMOCRACY AND DISTRUST 93-94 (1980); Vincent Blasi, The Checking Value in First Amendment Theory, 1977 AM. B. Found. Res. J. 521 (1977). Others have taken issue with the exclusive focus on matters of public concern, and have advanced a broader theory of freedom of speech based on the inherent value of individual liberty and selfrealization. See, e.g., C. EDWIN BAKER, HUMAN LIBERTY AND FREEDOM OF SPEECH 3-5 (1989); THOMAS I. EMERSON, THE SYSTEM OF FREEDOM OF EXPRESSION 6-9 (1970); MARTIN H. REDISH, FREEDOM OF EXPRESSION: A CRTICAL ANALYSIS 19-40 (1984). 
public employees against their governmental employer, may seem to be of peripheral importance at best.

There may appear to be nothing anomalous, then, in the contrast that I have described. It is hard to dispute that section 7 and the First Amendment, at their core, inhabit different ends of the spectrum running from particular work-related grievances to broader political and social concerns. Even so, this spectrum cannot be nicely divided as the two doctrines have purported to do. In each case the seemingly "peripheral" concerns that are excluded from protection-the political and product-related concerns of private employees and the work-related concerns of public employees-are intimately related to the core purpose of the respective guarantees of employee rights. The seemingly opposite limitations imposed in the two realms both stem from a blindness to the dynamic relationship between personal, concrete grievances at the workplace and broader public concerns.

The consequence of this blindness in the context of section 7 is not only to restrict unduly the scope of employee rights, but also to deny to the public important information about the conduct of significant economic actors. Drawing in part upon what the Court now conceives as the central, and perhaps the sole, justification for the constitutional protection of public employee speech-the importance of speech on matters of public concern in a democratic society-I argue for a broader interpretation of section 7 that protects the right to communicate and protest about matters beyond terms and conditions of employment.

\section{A. The Interests of Employees Under Section 7}

There is no doubt that the NLRA and section 7 of the Act were primarily concerned with the promotion of independent labor organizations and with collective bargaining over wages and other terms and conditions of employment. ${ }^{101}$ The Act was passed in the middle of the Great Depression, and raising wages was viewed as one key to economic recovery. How should the broad language of section 7 be read in light of this background? What does section 7 mean in this regard?

101 See generally IRVING BERNSTEIN, THE NEW DEAL COLLECTIVE BARGAINING POLICY 100-02 (1950). The preamble to the Act expresses these economic objectives. See National Labor Relations (Wagner) Act, Pub. L. No. 74-198, § 1, 49 Stat. 449, 449 (1935) (codified as amended at 29 U.S.C. $\$ 151(1988)$ ). 
These questions seem to beckon us to study the legislative history of the Act to determine what Congress intended by the phrase "mutual aid or protection." That sort of inquiry is met with increasing skepticism in some quarters of both the judiciary ${ }^{102}$ and the academy. ${ }^{103}$ Such skepticism is particularly well-placed with respect to a provision like section 7: it was enacted over a halfcentury ago, and its broad, open-textured language seems ill-suited to communicating a congressional intent to specify and delimit the permissible objectives of joint employee activity. Indeed, I would argue that section 7 presents a paradigmatic case for the application of "dynamic statutory interpretation" of the sort advocated in certain contexts by Professor William Eskridge. ${ }^{104}$ In other words, it makes more sense to interpret the broad general language of section 7 in light of the changing social context in which the statute operates than to attempt to read the tea leaves left by the 1935 Congress that enacted that provision. ${ }^{105}$ This approach is

102 A tilt away from "purpose" or "intent," as divined from legislative history, and toward the "plain meaning" of the text is a striking feature of the Supreme Court's recent cases involving statutory interpretation. See Frederick Schauer, Statutory Construction and the Coordinating Function of Plain Meaning, 1990 SUP. CT. REV. 231, 246; Cass R. Sunstein, Interpreting Statutes in the Regulatory State, 103 HARV. L. REV. 405, 415-16 (1989) (providing examples of recent Supreme Court cases where "textualism" is evident). Justice Scalia is the leading exponent of this approach. See, e.g., Green v. Bock Laundry Mach. Co., 490 U.S. 504, $527-30$ (1989) (Scalia, J. concurring in the judgment) ("The meaning of [statutory] terms ... ought to be determined, not on the basis of which meaning can be shown to have been understood by a larger handful of the Members of Congress;" but rather by (1) their ordinary usage and (2) their compatibility with existing law and the statutory framework); Blanchard v. Bergeron, 489 U.S. 87, 97-100 (1989) (Scalia, J., concurring in part and concurring in the judgment) (expressing skepticism concerning the use of committee reports as "evidence of what the voting Members of Congress actually had in mind" when a statute is enacted); Immigration and Naturalization Serv. v. Cardoza-Fonseca, 480 U.S. 421, 452-53 (1987) (Scalia, J., concurring in the judgment) ('Judges interpret laws rather than reconstruct legislators' intentions. Where the language of those laws is clear, we are not free to replace it with an unenacted legislative intent. "); Antonin Scalia, The Rule of Law as a Law of Rules, 56 U. CHI. L. REv. 1175 (1989) (discussing the need for "general rules" from the Court and stating that looking beyond the text of a statute is "essentially a discretion-conferring approach").

${ }^{103}$ For just a few of the scholarly expressions of skepticism about inquiry into "legislative intent," see GUIDO CALABRESI, A COMMON LAW FOR THE AGE OF STATUTES (1982); T. Alexander Aleinikoff, Updating Statutory Interpretation, 87 MICH. L. REv. 20 (1988); William N. Eskridge, Jr., Dynamic Statutory Interpretation, 135 U. PA. L. REV. 1479 (1987); Daniel A. Farber, Statutory Interpretation and Legislative Supremacy, 78 GEO. L.J. 281 (1989).

104 See Eskridge, supra note 103, at 1496.

105 Interpreting the intent of Congress with respect to section 7 is especially 
all the more appropriate with respect to section 7 because the evidence we do have suggests that Congress intended to create a charter of worker rights with room for growth and change in the nature of the objectives deemed important by workers themselves. ${ }^{106}$

The Wagner Act, and section 7 in particular, was based not just on an economic theory but on a commitment to the rights of workers to join together and assert shared interests and concerns at the workplace. In Senator Wagner's words, the Act was "'the next step in the logical unfolding of man's eternal quest for freedom." 107 Supporters invoked basic freedoms of expression and association in support of the rights affirmed in section $7 .{ }^{108}$ The goals and interests in pursuit of which employees might exercise those rights were not described by the familiar phrase "terms and conditions of employment," even though variations on this language were used elsewhere in the Act. ${ }^{109}$ That phrase readily evoked rather concrete matters like wages, hours, and job safety. Instead,

difficult. One must contend first with the belief held by many in 1935 that the Wagner Act would be struck down as unconstitutional. See BERNSTEIN, supra note 101 , at 120-23. Moreover, the Wagner Act reflects an unusually diverse set of overall policies and objectives, as Karl Klare has shown. See Karl E. Klare, Judicial Deradicalization of the Wagner Act and the Origins of Modern Judicial Consciousness, 19371941, 62 MINN. L. REv. 265 (1978) [hereinafter Klare, Judicial Deradicalization]. Professor Klare has thus argued that the Act contained "radical" elements-that is, elements "challenging rather than reinforcing the basic assumptions and power relations of workplace institutions" that could have led to "radical" changes, although, "[n]eedless to say, Congress did not 'intend' such changes." Karl E. Klare, Traditional Labor Law Scholarship and the Crisis of Collective Bargaining Law: A Reply to Professor Finkin, 44 MD. L. REV. 731, 758-59 (1985).

${ }^{106}$ My argument is roughly parallel to that of $\mathrm{H}$. Jefferson Powell with respect to constitutional interpretation. See H. Jefferson Powell, The Original Understanding of Original Intent, 98 HARV. L. REV. 885 (1985). Professor Powell argues, in short, that the originalist fixation on "the intent of the Founders" is wholly misplaced since the Founders did not intend to fix the meaning of the Constitution by reference to their own views about particular provisions. Id. at 930-32; see also Hans W. Baade, “Original Intent" in Historical Perspective: Some Critical Glosses, 69 TEX. L. REV. 1001, 1024 (1991) (arguing that "the framers of the Constitution . . . did not intend to bequeath their understanding of it to future generations in perpetuity"). I argue here, similarly, that attempting to locate specific congressional intentions about the objectives encompassed by section 7 is at odds with a congressional purpose to permit labor to determine its own interests and objectives.

107 BERNSTEIN, supra note 101 , at 115 (quoting Senator Wagner).

108 See id. at 147; see also infra notes 183-88 and accompanying text.

109 See National Labor Relations (Wagner) Act, Pub. L. No. 74-198, §§ 8(3), 9(a), 49 Stat. 449, 452-53 (1935). I am not arguing here that all of the matters discussed herein, such as product quality and safety, are themselves "terms and conditions of employment ${ }^{n}$ subject to the duty to bargain collectively. See infra note 224 . 
rather concrete matters like wages, hours, and job safety. Instead, workers were granted the right to engage in "concerted activity for mutual aid or protection."

By 1935 , when that phrase made its way into the Wagner Act, it had a short but respectable pedigree. ${ }^{110}$ It had first appeared in section 2 of the Norris-LaGuardia Act of 1932. ${ }^{111}$ That Act severely restricted the authority of federal courts to grant injunctive relief in labor disputes; section 2 was a largely precatory statement of national labor policy, which declared the basic right of workers to engage in collective bargaining and other "concerted activity for mutual aid and protection" free from employer interference and coercion. ${ }^{112}$ The same language was subsequently incorporated into section 7(a) of the ill-fated National Industrial Recovery Act of 1933 (NIRA), ${ }^{113}$ which for the first time gave employees federal rights against employer interference, but which was temporary in duration, virtually unenforceable in practice, and ultimately struck down as unconstitutional. It is worth noting that it was William Green, then President of the American Federation of Labor, who urged Congress to carry over the phrase from Norris-LaGuardia into the NIRA's declaration of worker rights. ${ }^{114}$ Subsequently, and with very little further discussion, ${ }^{115}$ it was carried into section 7 of the NLRA where it became for the first time an enforceable

110 The legislative history of this crucial language is recounted in detail in Fischl, supra note 21, at 843-54, and in Robert A. Gorman \& Matthew W. Finkin, The Individual and the Requirement of "Concert" Under the National Labor Relations Act, 130 U. PA. L. REV. 286, 331-46 (1981). I rely partly on their accounts.

$111 \mathrm{Ch} .90, \S \S 1-15,47$ Stat. 70, 70-73 (1932) (codified as amended at 29 U.S.C. $\S \S 101-115(1988))$.

112 The language of $\$ 2$ was viewed by one of its chief drafters, Felix Frankfurter, as "useful rhetoric... . intended as an explicit avowal of the considerations moving Congressional action." FeLIX Frankfurter \& NATHAN GREENE, THE LABOR INJUNGTION 212 (1930).

${ }^{113}$ Ch. 90, § 7(a), 48 Stat. 195, 198-99 (1933) (struck down in Schechter Poultry Corp. v. United States, 295 U.S. 495 (1935)). This section provided for the adoption by trade associations of codes of fair competition, each of which was to contain a condition that certain employee rights would be guaranteed.

114 As submitted to Congress, § 7(a) provided simply that "employees shall have the right to organize and bargain collectively through representatives of their own choosing." Gorman \& Finkin, supra note 110, at 337 (quoting H.R. 5564, 73d Cong., 1st Sess. $\S 7(a)(1)(1933)$ ). Green urged the addition of the broader language, including the right to engage in "other concerted activities for ... mutual aid or protection," from $\S 2$ of Norris-LaGuardia. National Industrial Recovery: Hearings on H.R. 5664 Before The House Comm. on Ways and Means, 73d Cong., 1st Sess. 117 (1933) (statement of William Green).

${ }^{115}$ See Fischl, supra note 21, at 852. 
employee right backed by reasonably effective sanctions and adjudication mechanisms. ${ }^{116}$ There is some evidence, then, that the labor movement itself is responsible for the inclusion of the "mutual aid or protection" language in what is now section 7. But what did the phrase mean?

It seems very likely, as Professor Fischl has shown, that the notion of "mutual aid or protection" has its roots in the labor movement itself and its historic ethos of "mutualism" and solidarity: support for the cause of another, often at some risk to one's own immediate welfare, in the interest of the class and movement of workers of which one is a part. ${ }^{117}$ Sometimes an act of solidarity may be based on a realistic expectation of reciprocity some time in the future. Often, however, it is not. ${ }^{118}$ This kind of solidarity, which is the very soul of the labor movement, is not pure altruism, but it defies the conventional view of rational self-interest. ${ }^{119}$ It was that conventional, narrow view of employees' self-interest that, in part, animated a hostile federal judiciary's condemnation of labor activity-boycotts, picketing and strikes-the objective of which went beyond the protester's own immediate wages and working conditions. ${ }^{120}$ In incorporating the idea of mutualism into national

116 The lack of an effective enforcement scheme behind $\$ 7(a)$ of the NIRA was one of the primary shortcomings that backers of the NLRA sought to address. See BERNSTEIN, supra note 101, at 100 .

117 See Fischl, supra note 21, at 850-52. Professor Fischl draws heavily on the work of the eminent labor historian David Montgomery. See DAVID MONTGOMERY, THE FALL OF THE HOUSE OF LABOR 2-4, 171 (1987).

118 That is often the case when a worker refuses to cross a "stranger" picket line-a picket line set up by a union other than the employee's own on behalf of employees of an employer other than the employee's own. Often the risk to the employee of discharge or permanent replacement, not to mention a temporary loss of pay, is not remotely outweighed by the fairly speculative possibility of reciprocity by the "stranger" union in the future. See Fischl, supra note 21, at 801 \& n.36.

${ }_{119}$ As Fischl has written, the concept of "mutual support" echoed in $\S 7$ is "an idea born of working-class experience, at odds with the crude individualism suggested by the mere promise of reciprocity, and steeped in notions of community and 'brotherhood.' Id. at 857 . This view is reflected, he argues, in an influential but frequently misunderstood decision by Judge Learned Hand, NLRB v. Peter Cailler Kohler Swiss Chocolates Co., 130 F.2d 503, 505-06 (2d Cir. 1942) ("The rest know that by their action each one of them assures himself, in case his turn ever comes, of the support of the one whom they are all then helping; and the solidarity so established is 'mutual aid' in the most literal sense, as nobody doubts."). See Fischl, supra note 21 , at $856-57$.

120 As Professor Fischl recounts, by the late 19th century labor's infliction of economic injury was usually privileged "only to the extent that the challenged conduct had as its purpose or object the advancement of the self-interest of the protesters." Fischl, supra note 21, at 843 . Most courts found the requisite self-interest in strikes 
labor policy, first with the Norris-LaGuardia Act and later with the NLRA, Congress can best be characterized as having rejected the pervasive hostility toward collective worker action that looked beyond immediate economic advantage in favor of the labor movement's own more generous conception of its self-interest. ${ }^{121}$

This understanding of the origins of the term "mutual aid or . protection" clearly calls for an extension of section 7 protection to include support of other employees, even absent any distinct expectation of reciprocal support in the future. ${ }^{122}$ To be sure, the infusion of section 7 with historic ideals of solidarity among workers does not by itself tell us much about the sorts of interests that workers were thought to have so as to justify "concerted activity for mutual aid or protection." But it does suggest that the insistence on a self-interested economic motive for concerted activity is misconceived, and it thus opens the door to employee concerns, like those I have discussed, that lie some distance from labor's tradition-

for higher wages and better working conditions, but there was far less tolerance for employees' support for similar actions of other employees, or for economic pressure in support of union recognition. See id. at 843-44. The hostility toward concerted action, together with the limited privilege based in self-interest, established in the common law, came to be incorporated into the federal courts' interpretation of the Sherman Act, ch. 647, 26 Stat. 209 (1890) (codified as amended at 15 U.S.C. \$§ 1-7 (1988)), and even the Clayton Act, ch. 323, 38 Stat. 730 (1914) (codified as amended at 15 U.S.C. $\$ \S 12-27(1988)$ ), which had sought to limit the federal courts' intervention in labor disputes. The result was that labor activity in support of ends regarded as too remote from the immediate self-interest of protesters, such as secondary pressures, was held to be an unlawful restraint of trade. See Duplex Printing Press Co. v. Deering, 254 U.S. 443 (1921); Fischl, supra note 21, at 843-45.

121 See Fischl, supra note 21, at 843-45. The drafters of the Norris-LaGuardia Act were chastened by the federal courts' ability, demonstrated in Duplex Printing, to evade Congress's attempts to modify the substantive law governing labor activity; they therefore focused on limiting the courts' jurisdiction. See id. at 846-48. The statute contained a very broad definition of "labor disputes," the jurisdiction of which was sharply limited, see Norris-LaGuardia Act, ch. 90, $\$ 13($ c), 47 Stat. 70, 73 (1932) (codified at 29 U.S.C. $\$ 113$ (c) (1988)), so to break out of the narrow conception of employees' "self-interest" that the courts had recognized. See Fischl, supra note 21, at 848-49. The Supreme Court has thus repeatedly rejected the view that the NorrisLaGuardia Act ousts the courts' injunctive powers only where the activity is motivated by the protesters' economic self-interest. See, e.g., Burlington N.R.R. v. Brotherhood of Maint. of Way Employees, 481 U.S. 429, 440-43 (1987) (applying Norris-LaGuardia to secondary boycott activity, and rejecting the view that protest must further the union's economic interests); Jacksonville Bulk Terminals, Inc. v. International Longshoremen's Ass'n., 457 U.S. 702, 713-14 (1982) (rejecting the view that "economic self-interest" is necessary for Norris-LaGuardia to be implicated, and applying the Act to a political boycott of ships from the Soviet Union).

122 See Fischl, supra note 21, at 842 (suggesting that this broader "interpretation is more consonant ... with the contemporaneous understanding of the provision"). 
al economic demands but that still plainly arise from the work experience.

Having located the origins of the term "mutual aid or protection" in the early labor movement, we might follow that road further and look to that movement's own conception of the range of legitimate employee interests. But the value of this inquiry is questionable, for it seems that the history of the early twentiethcentury labor movement could support nearly any view of the interests of labor. There is no doubt that the chief concerns of the labor movement then, as now, were wages, hours, job security, workplace safety and the like. ${ }^{123}$ But the movement was diverse and unruly, and contained within it socialist, communist, and reformist elements whose programs ran the gamut from proletarian revolution and worker control of industry, to opposition to World War I, the establishment of public kindergartens, the institution of tax reform, and the improvement of social welfare benefits. ${ }^{124}$

${ }^{123}$ The dominant forces within the American labor movement in that period, embodied in the American Federation of Labor (AFL) and particularly in the person and philosophy of Samuel Gompers, came to be distinguished by their narrow focus on the immediate economic interests of their members and on the use of collective bargaining and economic pressure to advance those interests. See IRVING BERNSTEIN, THE LEAN YEARS: A HISTORY OF THE AMERICAN WORKER 90-94 (1960); MONTCOMERY, supra note 117 , at 6 . But it was not always so. At the turn of the century, Gompers himself was proclaiming the broad social and political objectives of the labor movement. See William E. Forbath, The Shaping of the American Labor Movement, 102 HARV. L. REV. 1109, 1145-48 (1989). William Forbath has argued persuasively that the AFL's shift to "voluntarism" and hostility to state intervention grew in large part out of its crushing experiences with reform efforts in the era of substantive due process and with the oppressive regime of "government by injunction" in labor disputes. See id. at 1234-35. In any event, the AFL's commitment to pure voluntarism was shattered by the Great Depression. See BERNSTEIN, supra, at 345-55. Those within the Federation favoring greater government intervention won a decisive victory with the AFL's endorsement of unemployment insurance. See id. at 353-54.

${ }^{124}$ In the evocative words of Professor Montgomery, "[b]efore the 1920 s the house of labor had many mansions." MONTGOMERY, supra note 117 , at 6 . For discussions of the diversity of the American labor movement in this period, see BERNSTEIN, supra note 123, at 136-42; DAVID MONTGOMERY, WORRERS' CONTROL IN AMERICA 104-08 (1979); RICHARD H. TAWNEY, THE AMERICAN LABOUR MOVEMENT AND OTHER ESSAYS 39 (J.M. Winter ed., 1979); Forbath, supra note 123, at 1125. Some of the most influential union leaders in the AFL of the 1920s and 1930s were the advocates of "industrial unionism" who went on to form the Congress of Industrial Organizations in 1937. The industrial unionists broke from the AFL's old guard chiefly over the manner in which labor should be organized in the emerging mass-production industries to best advance their shared economic interests. But they also differed from the AFL in regard to their willingness to adopt political means and broader political aims. The early CIO pressed, for example, for much of the New Deal program apart from the Wagner Act and for tax reform. See TAWNEY, supra, at 
Surely Congress, in borrowing the term "mutual aid or protection" from labor's lexicon, cannot be presumed to have incorporated the revolutionary objectives for which some in labor's ranks agitated. By the same token, the labor movement did not speak with one voice on the strictly economic aims and interests of labor. Congress's use of open-textured language with roots in the labor movement itself seems designed not so much to insist on a particular vision of the interests of labor as it is to allow workers to speak for themselves and to choose the appropriate objects of their concern. The language invites us to listen to workers' own conceptions of their interests "as employees" rather than attempting to define those interests for them.

\section{Employee Concerns About Product Quality}

Current doctrine is based on the premise that employees are not advancing their interests as employees when they criticize their employer's products or services. This very formulation of the issue is revealing, for it obscures the fact that the "employer's" product or service is very often the employees' own work product.

But surely employees do have a genuine interest as employees in the quality of what they collectively produce. First, and most obviously, employees have a direct economic interest in the ongoing success of the enterprise on which their livelihoods depend. But employees' interest in the quality of their work product cannot be wholly ascribed to "rational self-interest," if that is thought to exclude genuine concern for quality and for the interests of others such as consumers. An employee's job satisfaction may turn just as much on her ability to take pride in the product of her efforts and in the institution of which she is a part as on her wages and the physical conditions in which she works. ${ }^{125}$ An employee's selfinterest and her interest in the quality of the product or service she helps provide converge in the pride and self-realization that come from contributing something of value to the community.

Considerations both of economic security and of personal satisfaction, depending as they do on the success of the organization, strongly inhibit employees' willingness to "go public" with

125 See ROBERT BLAUNER, ALIENATION AND FREEDOM at vii-ix (1964) (asserting that "the nature of a man's work affects his social character and personality ... and his over-all sense of worth and dignity"); RENSIS LIKERT, THE HUMAN ORGANIZATION 51 (1967) (suggesting that employees desire, in addition to economic security, "to be proud of the company they work for and of its performance and accomplishments"). 
tion, strongly inhibit employees' willingness to "go public" with criticism of the employer. ${ }^{126}$ But those same considerations might also eventually push employees in the other direction, especially if efforts to address the problem internally are frustrated. Employees might even conclude that criticizing the employer's product or service-informing the public of problems and pressuring the employer to institute changes-serves the long-run interests of the enterprise and its employees.

Professional employees, who are covered by the Act, provide some of the most obvious examples. ${ }^{127}$ Can it be doubted that the job satisfaction of nurses is intimately bound up with the welfare of their patients? ${ }^{128}$ That lawyers are committed to providing adequate representation to their clients? ${ }^{329}$ That journalists are concerned about the caliber of the information they and their publication provide to the public? ${ }^{130}$ And that each of these groups of employees has these concerns because of the work they do? It is strong evidence of the depth and sincerity of these concerns that professional employee unions have sought, often successfully, to bargain over these professional matters, ${ }^{131}$ for this presumably demonstrates their willingness to trade off potential economic demands for the sake of promoting professional concerns. Moreover, many professional employees are bound by professional ethics to act in the interest of their patients or clients and to adhere to standards of professional integrity that transcend whatever obligations of loyalty they may have to their employer. To the extent an employer's actions and policies undermine its employees' ability to meet professional standards, the employees may deem

126 There are, of course, other constraints, such as the fear of employer retaliation. See infra text accompanying notes 231-33.

127 See generally David M. Rabban, Can American Labor Law Accommodate Collective Bargaining by Professional Employees?, 99 YALE L.J. 689, 691, 714-16 (1990) (giving examples of professional employees seeking to advance "professional" concerns through collective bargaining).

${ }^{128}$ See id. at 715 (noting nurses' negotiation of provisions securing hospital adherence to professional nursing standards) (citing LYNDIA FLANAGAN, Collective BARGAINING AND THE NURSING PROFEssion 18-25 (American Nurses' Ass'n 1983)).

${ }^{129} \mathrm{See}$ id. (noting legal aid attorneys' negotiation for opportunities to address "issues of project-wide significance").

${ }^{130}$ See id. (noting reporters' negotiation for control over revisions) (citing Gail L. Barwis, Contractual Newsroom Democracy, 57 JOURNALISM MONOGRAPHS 1, 15, 17-18 (1978)).

131 See Rabban, supra note 127, at 714-16; see also David M. Rabban, Is Unionization Compatible with Professionalism?, 45 INDUS. \& LAB. REL. REV. 97, 110 (1991) (describing the treatment of professional concerns in collective bargaining agreements). 
themselves obligated to criticize and to attempt to change those policies. ${ }^{132}$ To define criticism of this sort as indefensible "product disparagement," unrelated to "the interests of employees as employees," is to misunderstand and demean the job experiences of these employees. ${ }^{133}$

Highly trained professionals are not, however, the only employees who transcend parochial pocketbook concerns. Abundant anecdotal evidence demonstrates the interest of nonprofessional employees in the quality and safety of the product or service they produce. The common law jurisprudence of "wrongful discharge" is replete with cases of secretaries, technicians, and other nonprofessional private employees who were discharged for expressing their concern about the safety or quality of the employer's product or service. ${ }^{134}$ In interviews, craft workers, ${ }^{135}$ construction work-

${ }^{132}$ Cf. Lawrence E. Blades, Employment at Will vs. Individual Freedom: On Limiting the Abusive Exercise of Employer Power, 67 CoLUM. L. REV. 1404, 1408-09 (1967) (describing the dilemma of professionals faced with an employer's demand that they violate professional ethics).

133 A glimmer of recognition of this point is buried in the decisions of the Board, and to a lesser extent of the court of appeals, in Misericordia Hosp. Medical Ctr., 246 N.L.R.B. 351 (1979), enforced, 623 F.2d 808 (2d Cir. 1980), discussed supra notes 75-77 and accompanying text. As a supporting rationale for protecting the nurses' report on patient conditions, the Board cited the nurses' obligation "to act to improve the standards of nursing care and to join with others to meet the public's health needs." Misericordia, 246 N.L.R.B. at 356. Broad acceptance of this argument would markedly expand the scope of section 7 protections for many professionals, for it would recognize that their shared concerns as professional employees necessarily encompass the concerns of those persons they are committed to serving and the standards they are pledged to maintain. The argument was relegated to a footnote by the reviewing court, see Misericordia, 623 F.2d at 814 n.9, which upheld the Board's decision based on the report's incidental reference to working conditions. I have been unable to locate any other decisions recognizing this kind of link between the interests of employees and the interests of others.

184 Such conduct is sometimes found to state a case for wrongful discharge under the "public policy" exception to the general presumption that employment is "at will." See, e.g., Boyle v. Vista Eyewear, 700 S.W.2d 859 (Mo. Ct. App. 1985) (lab helper fired for reporting employer's failure to perform federally mandated safety tests on eyeglasses); McQuary v. Bel Air Convalescent Home, Inc., 684 P.2d 21, 23 (Or. Ct. App. 1984) (employee fired for threatening to report violation of nursing home patient's rights under state law); $c f$. White v. General Motors Corp., 908 F.2d 669 (10th Cir. 1990) (employees fired for complaining of brake defects would state wrongful discharge claim but for valid release).

In other similar cases the "employment at will" doctrine bars the employees" wrongful discharge claims. See, e.g., Guy v. Travenol Labs, Inc., 812 F.2d 911 (4th Cir. 1987) (supervisor at drug manufacturing plant fired for refusing to falsify records of quality and quantity of drugs); Tritle v. Crown Airways, Inc., 751 F. Supp. 585 (S.D. W. Va. 1989) (airline employee fired for complaining of pilot's safety violations); English v. General Elec. Co., 683 F. Supp. 1006 (E.D.N.C. 1988) (radiation lab 
ers, ${ }^{136}$ auto workers, ${ }^{137}$ and waitresses ${ }^{138}$ describe pride in what they produce as an important element of their work experience. It seems likely that many nursing aides, child care -workers, and other nonprofessional employees of private service-oriented organizations, who tend to be relatively low-paid, may have chosen these less lucrative jobs because of the satisfaction they gain from serving people and doing good.

There is overwhelming evidence that workers want to contribute meaningfully to a socially productive enterprise, to produce highquality goods, and to deliver a valuable service. ${ }^{139}$ Some work experiences satisfy the deep-seated desire to identify with and take pride in the product of one's labors, resulting in enhanced "job

technician allegedly fired for complaining of safety violations at nuclear fuel plant); Geary v. United States Steel Corp., 319 A.2d 174 (Pa. 1974) (salesman fired for complaining about product quality); $f f$. Gaiardo v. Ethyl Corp., 835 F.2d 479 (3d Cir. 1987) (employee fired for refusing to falsify quality control reports failed to state a claim under the public policy exception to the at-will doctrine, though the claim was not "frivolous").

${ }^{135}$ See STUDS TERKEL, WORKING at xlv-xlix (1974) (quoting stone mason Carl Murray Bates as he talks about his work and its meaning); id. at 517-19 (quoting carpenter Nick Lindsay who discusses satisfaction in doing good work). See generally BLAUNER, supra note 125, at 51-57 (describing the satisfaction felt by printers with challenging and creative work).

136 See TERKEL, supra note 135, at 26 (crane operator Hub Dillard: "There's a certain amount of pride-I don't care how little you did. You drive down the road and you say, 'I worked on this road.' ... [T] [Tere's a certain pride lnowing you did your bit. ... It's food for your soul that you know you did it good.").

${ }^{137}$ See id. at 177 (auto worker Ned Williams: "You see [a car] on that highway, you don't look and see what model it is or whose car it is. I put my labor in it. And somebody just like me put their area of work in it. It's got to be an area of proudness.").

${ }^{138}$ See id. at 296-97 (waitress Dolores Dante: 'I'd get intoxicated with giving service. People would ask for me and I didn't have enough tables. . . That's a compliment. ... Y You really want to pleasure your guests. . . I I tell everyone I'm a waitress and I'm proud.").

139 See Special TaSk force to The Secretary of Health, Education and WELFARE, WORK IN AMERICA 13 (1973) [hereinafter WORK IN AMERICA] ("What the workers want most, as more than 100 studies in the past 20 years show, is to become masters of their immediate environments and to feel that their work and they themselves are important."); see also BLAUNER, supra note 125, at viii (stating that the nature of one's work affects one's "over-all sense of worth and dignity"); DENNIS A. GILBERT, COMPENDIUM OF AMERICAN PUBLIC OPINION 414 (1988) (describing the results of an opinion poll in which over $90 \%$ of respondents said that the quality of their company's product or service is important to them); LIKERT, supra note 125, at 51 (noting that studies show that employees want to be able to take pride in their company's performance and a'complishments); MIKE PARKER \& JANE SLAUGHTER, CHOOSING SIDES: UNIONS AND THE TEAM CONCEPT 98 (1988) ("Workers . . . like to be identified with a company and a product that their friends and neighbors see as high caliber."). 
satisfaction," morale, and productivity. ${ }^{140}$ Other job experiences frustrate those desires, yielding employee alienation, high turnover, and even sabotage. ${ }^{141}$ The auto industry stood for many years as the textbook illustration of the alienation and demoralization fostered by the assembly-line production method. ${ }^{142}$ But the desire of workers to make a contribution and to take pride in their work is hardy, and lies ready to be cultivated even after decades of neglect. The experience of the United Auto Workers and General Motors offers a case in point and vividly demonstrates the depth of employee concerns about product quality. ${ }^{143}$

140 See, e.g., BLAUNER, supra note 125, at 51-57 (describing satisfaction in the craft of printing); EDWARD E. LAWLER ET AL., EMPLOYEE INVOLVEMENT IN AMERICA: A STUDY OF CONTEMPORARY PRACTICE 46-48 (1989) (noting that large firms using "employee involvement" mechanisms report heightened worker satisfaction (76\% of firms), as well as improved quality (72\%) and productivity (69\%)); WORK IN AMERICA, supra note 139, at 96-105 (describing the success of programs to redesign jobs and enlist employee participation).

${ }^{141}$ See BLAUNER, supra note 125, at 21-24 (1964) (asserting that a lack of any control over the pace and processes of work renders it meaningless to the worker); HARRY BRAVERMAN, LABOR AND MONOPOLY CAPITAL 31-35 (1974) (explaining how job dissatisfaction may manifest itself in high absenteeism and quit rates); WORK IN AMERICA, supra note 139, at xvi-xvii (stating that job dissatisfaction is common in both blue and white collar jobs, and cuts across race, age, and gender lines); see also TERKEL, supra note 135, at xxxi (steelworker Mike Lefevre: "You can't take pride anymore. ... It's hard to take pride in a bridge you're never gonna cross, in a door you're never gonna open. You're mass-producing things and you never see the end result of it."). Terkel also quotes Gary Bryner, president of a UAW local in Ohio:

Assembly workers ... have no enthusiasm about pride in workmanship. They could care less if the screw goes in the wrong place. ... The guys are not happy here. They don't come home thinking, Boy, I did a great job today and I can't wait to get back tomorrow. . . . He's not concerned at all if the product's good, bad or indifferent.

Id. at 192-93; see also infra note 142.

142 See BLAUNER, supra note 125, at 5-6, 98-123; BRAVERMAN, supra note 141, at 32-34. Emma Rothschild describes GM's Lordstown plant after a famous strike in 1972 as "a world center of worker alienation." EMMA ROTHSCHILD, PARADISE LOST: The Decline of the Auto-Industrial Age 97 (1973).

The strike vote came after months of struggle: a change in plant management, layoffs, a disciplinary crackdown, an increase in car defects, complaints by workers about the speeding up of monotonous assembly-line tasks, slowdowns, high absenteeism, repeated allegations by GM of worker sabotage. Workers claimed that supervisors authorized shipment of defective cars; the company claimed that workers attacked the paint, body, upholstery, and controls of the Vegas.

Id. at 101.

${ }^{143}$ This is not to say that these developments will become the salvation of General Motors, the woes of which have many deep roots. See Doron P. Levin, Experts Doubt Cutbacks Alone Will Save G.M., N.Y. TimEs, Dec. 23, 1991, at A1. 
Since 1941 the company-wide collective bargaining agreement between the UAW and GM has proclaimed their joint commitment to product quality. ${ }^{144}$ But until recently this commitment was not reflected in any active effort to solicit or respond to the knowledge and concerns that line workers had about design or manufacturing issues. ${ }^{145}$ Increased competition in the automobile market forced a reexamination of the quality issue, prompting GM, together with the UAW and other unions, to create a "Quality Network" aimed in part at involving workers at all levels in decisions about product quality. In recent years the UAW has successfully negotiated for contract provisions guaranteeing extensive worker and union involvement in quality issues. ${ }^{146}$ Indeed, in its most recent round of contract negotiations with GM, the UAW sought the right to strike over product quality. ${ }^{147}$ Instead the union secured a new procedure permitting line workers to raise issues relating to product quality and to initiate a sort of "quality grievance" that can be taken all the way up the corporate ladder, with union involvement at every step. ${ }^{148}$

The experience of the $U A_{\perp} W$ and GM demonstrates the importance of quality issues to the employees, as represented by their union. The union's willingness to expend finite bargaining leverage on securing guarantees of worker participation in quality issues is convincing evidence of genuine interest and concern among employees. Further evidence is found in employee attitudes about their work: the company's research reveals widespread and increased interest among autoworkers in the quality of what they produce, as well as improved job satisfaction, stemming, at least in part, from their involvement in these issues. ${ }^{149}$

144 Agreement BetweEn General Motors CorP. AND the UAW 1 (1941) (copy on file with author).

145 On the contrary, autoworkers who expressed concerns of this nature were often frustrated by their supervisors' and management's lack of interest. See, e.g., ROTHSCHILD, supra note 142, at 97 (quoted supra note 142); TERREL, supra note 135, at 162 (autoworker Phil Stallings: "Proud of my work? How can I feel pride in a job where I call a foreman's attention to a mistake, a bad piece of equipment, and he'll ignore it. Pretty soon you get the idea they don't care.").

146 See UAW-GM Memorandum of Commitment to Product Quality, in AGREEMENT BETWEEN GENERAL MOTORS CORP. AND THE UAW, SEPT. 17, 1990 at 565-67 [hereinafter GM-UAW AGREEMENT].

${ }^{147}$ Conversations with UAW and GM officials (Mar. 14, 1991) (notes on file with author).

148 See GM-UAW AGREEMENT, supra note 146, at 418-21 (describing "an expeditious process flow for employees to voice their product quality concern[s]").

149 Conversation with GM officials (Mar. 14, 1991) (notes on file with author). 
The story is exemplary, but not unique. "Quality circles" and other programs to encourage employee participation in all aspects of the production process have proliferated in many areas of industry. ${ }^{150}$ Those programs are founded in large part on the fact, repeatedly verified in empirical studies, that such involvement enhances employee job satisfaction, longevity, and productivity, as well as product quality. ${ }^{151}$ Much of modern labor relations and personnel practices in both union and nonunion workplaces is thus founded on the premise that employees have an inherent, if sometimes latent, concern for the nature and quality of what they produce. It is an interest that employees generally share with employers, and indeed employers have begun to understand and to

${ }^{150}$ Another good example of joint labor-management efforts to improve quality and efficiency is provided by the Xerox Corporation and the Amalgamated Clothing and Textile Workers Union. See U.S. DEP'T OF LABOR, TRACING A TRANSFORMaTION IN INDUSTRIAL RELATIONS: THE CASE OF XEROX CORPORATION AND THE AMALGAMATED ClothING AND TEXTILE WORRERS UNION (1988) [hereinafter Tracing A TRANSFORMATION]. The growing trend toward employee involvement is confirmed by a mammoth study of employee involvement in almost 500 "Fortune $1000^{n}$ firms conducted for the General Accounting Office by the Center for Effective Organizations at the University of Southern California. See LAWLER ET AL., supra note 140, at 29-30. Some $70 \%$ of the respondents reported some form of worker involvement, particularly "quality circles," $i d$. at 25 , defined as structured employee participation in groups in which volunteers meet to identify quality and productivity-related problems and suggest improvements. See id. at 79.

151 This link between greater employee involvement in such matters as improving product quality and an increase in work satisfaction is confirmed by the large-scale GAO study referred to in the previous note. Over three-quarters of those respondents who had implemented some form of worker involvement plan reported improved worker satisfaction; over two thirds also reported improved productivity, quality of product or service, and customer service. See id. at 46-48; see also TRACING A TRANSFORMATION, supra note 150, at 11-12 (stating that volunteer participants in a "quality of worklife" program at Xerox reported improvements in morale and in their attachment to the job and to the firm, and that the program contributed positively to productivity, labor relations, and the union itself).

Not all of these programs genuinely enhance employee control at work; indeed, some labor activists argue that unions should resist participation schemes such as the "team concept." See PARKER \& SLAUGHTER, supra note 139, at 39-59; MIKE PARKER, INSIDE THE CIRCLE: A UNION GUIDE TO QWL (1985). These "adversarialists" argue that such cooperation schemes are simply sophisticated speed-up devices that exploit workers and undermine labor militancy, which they view as the only viable path to real power for employees. See PARKER \& SLAUGHTER, supra note 139, at 41 . But see Karl E. Klare, The Labor-Management Cooperation Debate: A Workplace Democracy Perspective, 23 HARV. C.R.-C.L. L. REV. 39, 82 (1988) (disagreeing with the claim made by adversarialists that conflict is the only method of securing labor rights). At the very least, all participants in the debate embrace the crucial point that workers have an interest in matters such as the quality of their work product and in having a voice in such matters. See PARKER \& SLAUGHTER, supra note 139, at 35, 98; Klare, supra, at $44-45$. 
capitalize on the value employees place on producing a quality product. But it is also an interest that, like concerns about wages and working conditions, can bring employees into conflict with management. The open-textured language of section 7 , read in light of the overwhelming evidence of the meaning of work for employees, should lead to the protection of employees' right to express their own concerns about the quality of the product or service they produce.

\section{Other Employee Concerns Beyond Terms and Conditions of Employment: The Case of Environmental Issues}

There has been no comparable proliferation of employersponsored "environmental circles" designed to stimulate greater employee concern about and participation in employer practices affecting the environment. Employers do not have the same obvious market-based incentives to improve environmental performance that they face with regard to product quality. The incentive to reduce pollution and other environmental harmsclassic "externalities" of the production process-depends not on ordinary market forces but largely upon legal compulsion, and the cost of compliance with environmental mandates is often a drag on productivity and profits. Stricter environmental regulation has therefore sometimes been perceived by employees as a threat to job security and wage levels, and has sometimes been opposed by labor unions on those grounds. ${ }^{152}$

To some extent that is changing. Public concern about the environment has mushroomed in recent years, leading to stricter regulation, more vigorous enforcement, and larger fines. ${ }^{153}$ Moreover, there is an emerging consumer preference for environ-

152 See James C. Oldham, Organized Labor, the Environment, and the Taft-Hartley Act, 71 MICH. L. REV. 935, 940-42 (1973); Pope, supra note 56, at 912. Under Eastex, it is clear that employee protest of environmental regulation on these grounds would generally be protected under $\$ 7$. See supra notes $21-29$ and accompanying text.

153 See generally Matthew L. Wald, Earth Day at 20: How Green the Globe?, N.Y. TIMES, Apr. 22, 1990, $\$ 1$, at 1 (documenting some environmental progress as concern for the environment reaches major corporations). This increased concern has been manifested in legislation such as the federal Clean Air Act, 42 U.S.C. $\$ \S 7401-7642$ (1988), in tougher state regulation, see, e.g., Richard W. Stevenson, Facing Up to a Clean-Air Plan, N.Y. TIMES, Apr. 3, 1989, at D1 (describing new air pollution regulations in California), and in proposals for tax incentives and penalties based on environmental practices, see Barnaby J. Feder, Protecting the Environment: How Much Can Tax Policy Do?, N.Y. TIMES, Apr. 15, 1990, § 3, at 7. 
mentally sound products. ${ }^{154}$ Both of these developments have obvious bottom-line consequences: the economic interest of the firm and its employees seems increasingly to be served by responsible environmental practices.

But there are other grounds for employee concern about these matters. As with product quality, employees have a legitimate stake in being part of an enterprise that does good and not harm. This is particularly true when the employees themselves are required by the employer to engage in conduct that is damaging to the environment. Moreover, as residents of the community in which the employer operates, employees are especially likely to be affected by employer practices that contaminate the air, water, and soil in a locality. ${ }^{155}$ For all these reasons, employees do protest offenses against the environment and environmental regulations, ${ }^{156}$ and some labor unions have taken an affirmative stance on environmental issues, often together with community groups. ${ }^{157}$ The UAW and other unions have attempted to bargain over environmental issues, and have undertaken worker education programs with

${ }^{154}$ See John Holusha, So, What Is 'Environmentally Friendly'?, N.Y. TIMEs, Jan. 26, 1991, § 1, at 50; Keith Schneider, Can Shoppers Tell if Something Is Really Good for the Planet?, N.Y. TIMES, July 14, 1991, § 4, at 6 .

155 See Oldham, supra note 152, at 946-53.

${ }^{156} \mathrm{See} i \mathrm{~d}$. at 953-55. Wrongful discharge cases again provide examples. See, e.g., Trombetta v. Detroit, T. \& I.R.R., 265 N.W.2d 385, 388 (Mich. Ct. App.) (employee fired for refusing to falsify sampling data for pollution control reports to state), app. denied, 403 Mich. 855 (1978); Phipps v. Clark Oil \& Ref. Corp., 408 N.W.2d 569, 570 71 (Minn. 1987) (service station employee discharged for refusing to violate federal law by pumping leaded gasoline into vehicle designed for unleaded gasoline); Sabine Pilot Serv., Inc. v. Hauck, 687 S.W.2d 733, 734-35 (Tex. 1985) (deckhand fired for refusing to pump bilges into water in violation of federal law).

157 See, e.g., Frances F. Marcus, Labor Dispute In Louisiana Ends with Ecological Gain, N.Y. Times, Jan. 3, 1990, at A16 (describing Oil, Chemical \& Atomic Workers Union's successful campaign for tighter environmental regulation). See generally Oldham, supra note 152, at 966-77 (describing the efforts of several major unions to have input into environmental decisions); Pope, supra note 56, at 903-04 (describing an overlap between workers' concerns about pollution and those of the larger community). As early as 1970, at the urging of its long-time president Walter Reuther, the UAW resolved:

Unchecked pollution by the automobile and related industries is of direct concern to auto workers not only because they are citizens concerned for their environment but because there is a direct threat to their jobs and their job security. The worker's stake in resolving this problem for society and the nation is compounded by the stake in his own job. We shall raise this issue sharply in 1970 negotiations in discussions with the companies.

Oldham, supra note 152 , at $936-37$. 
respect to them. ${ }^{158}$ Those activities reflect legitimate employee concerns growing out of their participation in the production process. To the extent the activities are concerted in nature, they should be protected by section 7.159

My claim is not that workers are uniformly selfless and publicspirited. Wages and benefits are necessarily foremost among the concerns of employees. Concerns about the quality of the product, the environmental practices of the employer, or other issues of public interest may be secondary at best for most employees. Moreover, these concerns may themselves be inextricable from the employees' collective long-term interest in job security. But can it fairly be said, as a categorical matter, that the employer's toxic contamination of the surrounding community or the quality of the collective work product is of less legitimate concern to employees than, for example, the price of soft drinks in employer-provided vending machines? ${ }^{160}$ As a matter of national labor policy, should employees be encouraged to focus their energies wholly on the latter rather than on matters such as quality and compliance with environmental and other public duties?

Like solidarity among workers, concern about the work product and other outside effects of the production process, such as environmental practices, is neither strictly self-interested nor wholly altruistic. It is a reflection of workers' ability to see connections between their own interests "as employees" and the interests they share with other consumers and citizens of their communities. ${ }^{161}$ Much the same can be said of "political activity" whose relationship to employees' terms and conditions of employment may appear "attenuated": employees may, in part through their participation in a union and other concerted activity at the workplace, develop a

${ }^{158}$ See Oldham, supra note 152 , at $967-71$.

159 Professor Oldham concluded in 1973 that such activity was generally already protected. See $i d$. at 1002-03. I must disagree. His analysis of the status of such activities under $\S 7$ relies largely on cases involving occupational health issues. See id. at 1003-08. If complaints about contamination or pollution of the work environment are put aside, most cases involving environmental complaints do not entail the direct effect on working conditions that is generally a prerequisite to $\S 7$ protection.

160 The latter has been held to constitute a "condition of employment" about which the employer is required to bargain under $\S 8(\mathrm{a})(5)$ and $\S 8(\mathrm{~d})$. See Ford Motor Co. v. NLRB (Chicago Stamping Plant), 441 U.S. 488, 498-500 (1979).

${ }_{161}$ Professor James Pope demonstrates how the cultivation of those connections holds out the promise for a reinvigoration of labor activism, if only it can overcome the traditional constraints of the labor laws. See Pope, supra note 56, at 894-98. 
more inclusive sense of their own interests. ${ }^{162}$ They may become educated about the innumerable ways in which decisions in the political sector affect working conditions-their own and those of others-and they may come to see their interests as tied to the welfare of others. ${ }^{163}$

The restriction of section 7 protection to activity motivated by economic self-interest rests on an impoverished understanding of what work means to people: it denies that employees have a genuine and legitimate interest in the broader implications of their work. Yet the interests of employees are defined not just by the terms of their relationship with the employer but also by the work they do, the product they produce, the services they perform, and the enterprise to which they belong. Indeed, employees' desire for valuable and meaningful work becomes more salient to the extent that their basic material needs-a decent wage, a tolerably safe workplace, reasonable hours-are satisfied. ${ }^{164}$ Historically, then, these "higher" needs have assumed greater importance to many groups of workers since the 1930 s, largely as a consequence of economic gains made through economic growth, collective bargaining, and government regulation. ${ }^{165}$ In that sense, the meaning of work, and of a "good job," has changed since the Wagner Act was passed.

The language of section 7 is generous enough in scope to accommodate these increasingly prominent desires of employees. When employees come to share broader concerns for quality and public safety and social responsibility such that they are moved to act in concert for the sake of those concerns, they engage in "concerted activity for mutual aid or protection" within the meaning

162 See id. at 902-03. The comments of a union shop steward provide anecdotal evidence of this development: "Before the union came in, all I did was do my eight hours, collect my paycheck, and go home . . . . I had no outside interests. . . . Since $I$ became active in the union, I've become active in politics, in the community, in legislative problems." TERKEL, supra note 135, at 292 (quoting factory worker Grace Clements).

163 This appears to have been operating in the UAW case, described supra text accompanying notes 144-48.

164 See generally A.H. MASLOW, MOTIVATION AND PERSONALITY 98-101 (1954) (arguing that people have a hierarchy of needs, such that when "lower" physiological and safety needs are met, "higher" needs for esteem and moral fulfillment emerge). Maslow's concept of a hierarchy of needs was applied to the context of work in the influential federal report referred to above. See WORR IN AMERICA, supra note 139, at 11-12.

165 See WEILER, supra note 8, at 35. 
of section 7, and should be protected from employer retaliation by the Act.

\section{B. The Interest of the Public in the Conduct of Private Enterprise}

An interesting counterpoint to section 7 is found, as discussed above, in the public employee speech doctrine. This doctrine, expressed most clearly in Connick v. Myers, ${ }^{166}$ is based on a particular view of the central meaning of the First Amendment-a view that divides the sphere of constitutionally protected speech into a core and a periphery. On that view, speech relevant to selfgovernment is at the heart of the First Amendment's protection of freedom of speech; other speech, complaints about working conditions and the like, is peripheral, and simply not important enough to warrant the intrusion into governmental operations that would necessarily attend broader First Amendment coverage of public employees. ${ }^{167}$ Moreover, Connick rests on the belief that speech on workplace matters is separable in a meaningful and consistent way from speech on matters of public concern, and that permitting suppression of the former will do no significant harm to the latter.

As I have argued elsewhere, those critical propositions do not stand up to scrutiny. ${ }^{168}$ Speech about important aspects of peoples' lives, including the workplace, cannot sensibly be distinguished from speech on public issues. ${ }^{169}$ People form political beliefs and

${ }^{166} 461$ U.S. 138 (1983).

167 The Court in Connick conceded that the First Amendment protects more than speech on matters of public concern. See id. at 147. It presumably would be unconstitutional to arrest someone for complaining about their working conditions even though that same person can now be fired for such speech. See id. The decision in Connick is thus not based on the conclusion that the First Amendment simply extends no further than the protection of speech on matters of public concern. I have argued elsewhere, however, that Connick, together with Dun \& Bradstreet, Inc. v. Greenmoss Builders, Inc., 472 U.S. 749, 755-61 (1985), which adopts a public concern test as a limit on First Amendment protections of libel defendants, may foreshadow a widespread imposition of a "public concern" requirement in a variety of areas of First Amendment doctrine. See Estlund, supra note 51, at 2.

${ }^{168}$ See Estlund, supra note 51, at 37-39.

169 The distinction between the "private" sphere of labor relations and the "public" sphere of politics is a recurring theme in scholarly critiques of the law governing labor and employment relations. See Hyde, supra note 21, at 4; Karl E. Klare, The Public/Private Distinction in Labor Law, 130 U. PA. L. REv. 1358, 1361 (1982); Pope, supra note 56, at 896; Katherine Van Wezel Stone, The Post-War Paradigm in American Labor Law, 90 YALE L.J. 1509, 1579-80 (1981). 
are moved to political and social action largely out of their own experiences in the world, including those of the workplace. ${ }^{170}$ It may be a "personnel" matter-a sense of being exploited or mistreated or harassed by one's bosses-that begins the public employee's venture into the domain of public discourse. ${ }^{171}$ Moreover, communication of these individual grievances among fellow employees, like that which Sheila Myers was attempting, is often a necessary step in the process of identifying shared concerns and formulating collective demands. By eliminating protection for work-related protests of this sort, the Connick public concern test discounts the importance of speech grounded in the everyday experience of ordinary people, in the workplace and elsewhere, and deprives each public employee of the very legal protections she may need in order to discover and join with those who share her concerns, and thereby translate immediate self-interest into broader demands on the polity. ${ }^{172}$

The limitations on employee rights in Connick and in section 7 are two sides of the same coin. In seeking to banish workplace concerns from the domain of free speech enjoyed by public employees, Connick denies the continuity between concrete grievances and the political demands that those grievances may generate. Section 7 doctrine reflects a contrary response to the same blindspot: the insistence on narrow economic self-interest as the key to section 7 protection impedes the emergence of a more inclusive conception of self-interest-and of solidarity, political activism, and genuine concerns about the quality, safety, and integrity of the work product-out of more parochial workplace interests. ${ }^{173}$ Just as Connick discounts the role of the particular

${ }^{170}$ For example, Professor Pope has recounted the development of vital community movements, revolving around concerns for the environment and racial, gender, and economic justice, out of workplace conflicts. See Pope, supra note 56, at 891-94.

${ }^{171}$ See supra text accompanying notes 44-46. Witness the saga of Professor Anita Hill, whose allegations of sexual harassment at the hands of her former boss, nowJustice Clarence Thomas, carried her into the Senate Judiciary Committee hearings and, via television, into the homes of most Americans. This episode is widely credited with galvanizing public and legislative support for those provisions of the Civil Rights Act of 1991, Pub. L. No. 102-166, 105 Stat. 1071 (1991), that afford a damage remedy to victims of sexual harassment, and with spurring Congress for the first time to make its own members and staff accountable for claims of discrimination. See Judy Mann, Feminism, Alive and Well, WASH. POST, Nov. 1, 1991, at D3. This episode dramatically illustrates how public debate and even federal legislation can originate in the personal grievances of a particular employee.

172 See Estlund, supra note 51, at 36-39.

${ }^{173}$ See Pope, supra note 56, at 891-94, 921-22, 931, 936 (providing examples of 
grievance in generating "public concerns," section 7 doctrine is sometimes blind to the ways in which "public," consumer-oriented, or solidaristic concerns of employees emerge from and in turn transform workplace experiences and interactions.

But Connick itself also contains the seeds of a different criticism of the limitations on section 7 protection. Prominent in the Supreme Court's pronouncements in this area is the interest of the public in learning what the public employee knows about the operations of government. ${ }^{174}$ The public employee speech doctrine encourages disclosure of the sort of information that the public employee is particularly-often uniquely-able to provide. The protection of public employee speech, in this view, is not just the vindication of the individual rights of public employees, but serves a special function in promoting informed self-government.

The advent in Connick of the threshold public concern requirement represents a notable turn toward the latter, systemic rationale for protecting public employee speech. ${ }^{175}$ First Amendment protections of public employee speech are now limited to public issues not because the employee has no right to speak on other matters, ${ }^{176}$ but because it is only those matters that the broader public is thought to have a special interest in hearing about. Under Connick public employee speech has come to be viewed as the handmaiden of democracy rather than as the exercise of an individual right guaranteed by the Constitution.

This development in First Amendment law is ill-advised, I believe, in part because it ensures that much speech of genuine public concern will be silenced, if it does not simply remain unspoken. ${ }^{177}$ But what the public concern test does protect is

this development).

174 See, e.g., Connick v. Myers, 461 U.S. 138, 145-46 (1983); id. at 161-62 (Brennan, J., dissenting); Arnett v. Kennedy, 416 U.S. 134, 228 (1974) (Marshall, J., dissenting); Pickering v. Board of Educ., 391 U.S. 563, 571-72 (1968).

175 The Court's explanation for the public concern requirement relies heavily on the importance of speech on public issues to an informed citizenry and to selfgovernment. Connick, 461 U.S. at 145-46; cf. Lieberwitz, supra note 7, at 636-38, 65051 (noting that Connick stresses the instrumental value of speech for society, not its intrinsic value to the individual).

176 See supra note 167.

177 See Estlund, supra note 51, at 32-51. See generally Massaro, supra note 7, at 4-5 (arguing that the Supreme Court's approach to public employee speech fails to provide adequate protection for the employee's interest in free expression). By denying public employees constitutional protection for criticism of their employer when their own interests are directly implicated, the public concern test contemplates that much information that would be useful to the public will never be brought to 
clearly worthy of protection. The public does indeed have a strong interest in learning about the honesty or corruption of public officials, abuses of power or mistreatment of wards of the state, the environmental consequences of government actions, and shortcomings in the service provided by a government agency. The public concern test, while problematic in many ways, thus affirms the special role that public employees often play in bringing to light information on such issues and enhancing the accountability of public officials to the people.

The same public interest is implicated by the speech of private sector employees, for much of what is left unprotected by section 7 as insufficiently related to terms and conditions of employment is the very sort of speech that the public has the strongest interest in hearing. The quality of medical services, the safety of a nuclear power facility or a commercial airline, the care received by residents of a private drug treatment center or nursing home, the environmental practices of private firms, even the quality of television service provided by one of a small number of publicly licensed broadcasters in the area-these are all matters of self-evident public concern under any but the narrowest understanding of the term. ${ }^{178}$ Indeed, the Supreme Court has recognized a strong enough public interest even in mundane commercial information, such as the prices and quality of commercial goods, to justify the substantial constitutional protections extended to commercial advertising in the last fifteen years. According to the Court, "the free flow of commercial information is indispensable ... to the formation of intelligent opinions as to how [the free enterprise] system ought to be regulated or altered."179

There is no need here to enter into the debate within First Amendment jurisprudence as to the meaning and relative importance of "political" and other kinds of speech in our constitutional

light. The working conditions of public employees-in Sheila Myers' case, low morale and mistrust within an important government office-are very often immediately relevant to the agency's effective performance of its functions. Yet it is inevitable that those most motivated and likely to bring these problems to light will often be those who have been personally aggrieved in some way.

${ }^{178}$ See ATLESON, supra note 40, at 85 (noting the obvious community interest in the speech at issue in Jefferson Standard); Klare, supra note 169, at 1364 (asserting that "[t]he quality of a public licensee's service is, of course, a matter" of public concern).

179 Virginia State Bd. of Pharmacy v. Virginia Citizens Consumer Council, 425 U.S. 748, 765 (1976). The Court went so far as to declare that the "consumer's interest in the free flow of commercial information . . . may be as keen, if not keener by far, than his interest in the day's most urgent political debate." Id. at 763. 
scheme. ${ }^{180}$ I am not arguing that the First Amendment itself protects the speech of private-sector employees against retaliatory discharge, or requires that section 7 be interpreted to afford such protection. ${ }^{181}$ I contend simply that the public has an interest in hearing what the private-sector employee has to say about the conduct of his or her employer outside the immediate realm of personnel and labor relations matters. This public interest is recognized in First Amendment decisions; it is also driving the growth of one branch of state wrongful discharge law-the "public policy" exception to the presumption of "at-will" employment. ${ }^{182}$ Extending section 7 protection to concerted employee speech on issues of concern to consumers and the broader public would serve the public interest in receiving this information as well.

I hasten to acknowledge that the NLRA was not enacted to promote the public interest in learning about how private employers conduct themselves outside the labor relations context. No such interest is explicitly protected by the statute, nor does this policy consideration figure as such in the legislative history of the Act. But this concession is hardly fatal. As I have argued at length, much of the speech that would usefully inform the public also is linkedalbeit in ways not traditionally recognized-to the interests of employees as employees, and to their working experience. Those employee interests are sufficient to justify the expansion of section 7 rights proposed here. The public interest in receiving information critical of private employers is proffered here as an additional reason for favoring an otherwise reasonable interpretation of the scope of section 7 .

For those with a more adventurous view of statutory interpretation, however, I would go one step further; for a strong case can be made that the statute invites the application of quasi-constitutional considerations such as these in its interpretation. The rights recognized in section 7 were characterized by Senator Wagner and the Act's supporters as "elemental," as somehow more basic than, even prior to, any statutory enactment. ${ }^{183}$ The Supreme Court

${ }^{180}$ For a schematic review of varying attempts to define the scope of the First Amendment, and particularly of "political" or "public issue" speech, see Estlund, supra note 51 , at $44-46$.

181 Others have challenged the coherence of the state action barriers to such claims. See Lieberwitz, supra note 7, at 629 n.208 (collecting sources).

182 As I discuss below, however, that body of law affords only fragmentary protection even to the few who can afford to invoke it. See infra text accompanying notes 254-256.

${ }^{183}$ See, e.g., 79 CONG. REC. 7565 (1935), reprinted in 2 NLRB, LEGISLATIVE 
echoed this view in upholding the Act: the Court described the rights of collective protest and association at the heart of section 7 as "fundamental," 184 suggesting that those rights existed prior to and independent of the Wagner Act's explicit recognition and enforcement of them. And indeed, in one sense those rights clearly did predate the Wagner Act, for they are grounded in basic freedoms protected by the Constitution. Congress repeatedly invoked constitutional values of freedom and democratic selfdetermination in support of the statute. ${ }^{185}$

What significance does this have in the interpretation of section 7? Professor Clyde Summers has argued persuasively that the enactment of the NLRA represents a paradigmatic instance of

HISTORY OF THE NATIONAL LABOR RELATIONS ACT, 1935 [hereinafter LEGISLATIVE HISTORY OF NLRA] at 2321-22 (statement of Sen. Wagner: describing bill as "the next step in the logical unfolding of man's eternal quest for freedom," the "cornerstone of industrial liberty"); 79 Cong. Rec. 9691, reprinted in LEGISLATIVE HISTORY OF NLRA at 3132 (statement of Rep. Withrow: this bill guarantees to labor " $[t]$ he right of self-government through fairly chosen representatives[-]a right which is inherent to the American people"); Labor Disputes Act, Hearings on H.R. 6288 Before the House Comm. on Labor, 74th Cong., 1st Sess. 247 (1935), reprinted in LEGISLATIVE HISTORY OF NLRA at 2721 (statement of Frank Dillon: "Congress must preserve for the working people of the United States theirfundamental and basic rights"); To Create a National Labor Board: Hearings on S. 2926 Before Comm, on Education and Labor, 73rd Cong., $2 d$ Sess. 19 (1934) [hereinafter " 1934 Senate Hearings"), reprinted in LEGISLATIVE HisTORY OF NLRA at 49 (statement of Hon. Frances Perkins, Sec. of Labor: "the right of workers to organize and deal collectively with their employers existed befroe section 7(a) of the National Recovery Act" (the predecessor to $§ 7$, see supra text accompanying notes 113-16)); 1934 Senate Hearings at 115, reprinted in LEGISLATTVE HISTORY OF NLRA at at 145 (statement of Dr. Francis Haas, member of National Labor Board: \$7 of NIRA, see supra text accompanying notes 113-16, "declare[s] that [workers] may exercise rights which nature gives them" ${ }^{n}$ ), 1934 Senate Hearings at 136, reprinted in LEGISLATIVE HISTORY OF NLRA at 166 (statement of Jacob Panken: this bill is "protective of the rights of Americans to organize themselves and to give expression to their opinions without interference, intimidation, or coercion ..."); 1934 Senate Hearings at 190, reprinted in LEGISLATIVE HISTORY OF NLRA at 220 (statement of Dr. John Lapp: workers' "right to act in unison ... is an elemental right of man"); National Labor Relations Board: Hearings on S. 1958 Before the Senate Comm. on Education and Labor, 74th Cong. 1st Sess. 310 (1935) [hereinafter "1935 Senate Hearings"], reprinted in LEGISLATIVE HISTORY OF NLRA at 1696 (statement of Gordon Merritt in opposition to bill: affirming "the natural right and natural freedom of employees to organize"); 1935 Senate Hearings at 871, 885, reprinted in LEGISLATIVE HISTORY OF NLRA at 2257, 2271 (statement of William Leiserson, Chairman, National Mediation Board: referring to "the constitutional rights of employees to associate themselves").

184 See NLRB v. Jones \& Laughlin Steel, 301 U.S. 1, 33-34 (1937).

185 See supra note 183. This aspect of the legislative history of the Wagner Act has been reviewed by several scholars. See Gorman \& Finkin, supra note 110, at 339-44; Lynd, supra note 10, at 713-15; Summers, supra note 10, at 697-98. 
Congress stepping across the "state action" threshold and expanding the reach of constitutional freedoms into the sphere of private relations. ${ }^{186}$ Congress sought to protect employees' exercise of basic rights of free expression and association against employer retaliation as well as against state suppression. ${ }^{187}$ Professor Summers has argued further that "when Congress acts to protect or promote constitutional values, the courts and administrative agencies in interpreting and applying the statute should weigh those values in constitutional terms." 188

When Congress acted to protect employees' rights to join together and to protest matters of shared concern, and to appeal to the public for support on such matters, it acted to effectuate values of constitutional dimension, albeit beyond the arena of state action. When we "weigh those values in constitutional terms," we may fairly consider not only the interest of employees in speaking out on matters of concern to them, but also the public interest in hearing what the private-sector employee has to say, and not only about the traditional economic demands of labor but equally about such matters as the quality and safety of the product or environmental practices. Connick highlights the paramount importance in a democratic society of speech on matters of public concern, and recognizes the special role that employees can play in bringing such matters to light. That public interest, consonant as it is with the interests of employees at the core of the Act, is worthy of consideration in the private sector as well, and supports the expansion of section 7 rights called for here.

This may seem to be an unorthodox and controversial approach to statutory interpretation, ${ }^{189}$ and my conclusions about section

${ }^{186}$ See Summers, supra note 10, at 701.

${ }^{187}$ In Professor Summers' words:

[T] he core of labor law is protection and promotion of constitutional values. Freedom of association and the closely-linked freedom of expression are protected against employer restraints because such freedoms are preconditions to the declared national policy of encouraging collective bargaining, and collective bargaining is to be encouraged because it promotes the constitutional values of democratic decision-making and due process at the workplace.

Id.

${ }^{188} \mathrm{Id}$. at 702. In other words, "[w] freedoms from private controls or to promote democratic processes in private institutions, then the presumption should be that those values are to have predominate weight." Id.

${ }^{189}$ Professor Eskridge demonstrates, however, that "[f]or an old, generally worded 
7 do not strictly depend on it. The public interest in the freer flow of information about important private economic actors has the virtue of being in harmony with the interest of employees in speaking freely about matters of concern to them at the workplace, an interest that is explicit and paramount in the NLRA.

\section{ExPANDING THe Scope of Protected Protest UNDER}

Section 7: A Proposal AND ITS ConseQuences

For the reasons just discussed, section 7 should be construed to recognize the interests of employees not only in their terms and conditions of employment but also in the effect of the employer's operations on consumers, patients and other outside third parties. To that end I here propose a redefinition of the scope of "mutual aid or protection," the thrust of which is to leave the determination of the appropriate subjects of employee concerns largely in the hands of employees themselves. Within a very broad arena of potential subjects of employee concern, the simple fact of concerted activity among employees should be sufficient to trigger section 7 protection. As I have noted, the apparently dramatic consequences of this expansion of section 7 coverage are sharply limited by other restrictions on section 7 rights under existing law as well as by certain practical constraints on employee protest.

\section{A. The Proposed Definition: Expanding the Range of Recognized Employee Interests}

I have offered two sorts of reasons for expanding the scope of section 7, one focusing on the interest of employees in speaking out, the other on the interest of the public in hearing what these employees have to say. Both arguments indicate the need for an

statute that has been the subject of much litigation, the original legislative expectations actually carry very little weight in the interpretive process, whatever rhetoric the Court uses to justify its result." Eskridge, supra note 103, at 1539-40. And indeed, traditional canons of statutory interpretation support the consideration of public policy in choosing among broader or narrower interpretations of a statute. See NORMAN J. SINGER, SUTHERLAND STATUTORY CONSTRUCTION \$\$ 56.01-56.04 (4th ed. 1984). All three of the traditional sources of public policy-statutes, the Constitution, and the common law-provide reasons for adopting a broader reading of $\S 7$. The statutory policy of the Act and of other statutes governing employment is discussed supra notes 107-24 and accompanying text; constitutional policy is also described above, see supra notes $183-88$ and accompanying text; the common law policies articulated in the evolving law of wrongful discharge are treated below, see infra text accompanying notes 272-75. 
extension of section 7 protection to include protests that touch on employees' role as producers of goods and services, and as participants in enterprises that have an impact on the outside world. Section 7 should thus be expanded to presumptively protect any concerted communication or protest by employees about the conduct of the employer as it affects the public. As under existing section 7 doctrine, this proposal would not identify particular kinds of company decisions as either exposed to or shielded from employee protest; instead, the crucial factor would be the nature of the employees' appeal.

On this reading of section 7 , the nurses, nuclear plant construction workers, and drug counsellors discussed above, and even the Jefferson Standard technicians, would all presumptively be protected in their criticism of the product or service they participated in bringing to the public. Closely analogous, and similarly protected, would be speech about consequences of the employer's production process, such as environmental hazards. Employees who come to have such concerns, and to share them with fellow employees, are seeking to advance their interests "as employees" and are thus engaged in activity for "mutual aid or protection." Employees have a legitimate stake in being part of an enterprise that does good and not harm in the society. ${ }^{190}$

On the other hand, the proposed definition would deny protection to employees engaged in purely internal disputes over management decisionmaking within the company without regard to their effects on either terms and conditions of employment or the interests of consumers or the public. Thus, employees who become enmeshed in intra-management disputes about the allocation of authority within an organization, management philosophy, or fundamentally personal rivalries or conflicts would not generally be protected. Similarly, employee agitation on behalf of shareholders alone would remain beyond the scope of section 7. After all, such

${ }^{190}$ A close question would arise as to the status of concerted employee protest of the employer's use of its financial resources for ends opposed by the employees, for example, investments in South Africa or right-wing political contributions. On the one hand, this might seem to stretch beyond recognition the concept of employees' interests "as employees." Such protests would not involve the employees' work product or the productive process in which they participate. On the other hand such protests would involve the impact of the enterprise on the society at large. While I acknowledge it is a close call, I would hold that in the unusual case in which such topics become the subject of concerted activity among employees, that activity should be presumptively protected, subject to the ubiquitous restrictions on time, place and manner that I discuss below. See infra text accompanying notes 214-33. 
cases would typically involve employees who, purporting to assert the interests of the firm's owners, are fired by those already appointed to safeguard those interests, namely, management. When employees involve themselves in a purely internal dispute of this nature and manifest no concern for themselves as employees or for others outside the firm, there is simply no occasion for public intervention under section 7.

One central implication of the definition proffered above is that the scope of protected political activity by employees at the workplace, as well as the permissible scope of solidaristic activity on behalf of other employees, would be expanded. ${ }^{191}$ Once we recognize that employees have a legitimate stake in aspects of their employer's conduct that go well beyond its labor policies and practices, it follows that section 7 must protect a much broader range of "political" speech. Thus, for example, section 7 would protect employees who speak out in favor of regulation aimed at the product or services provided by their employer, or of environmental policies that would affect the employer; by the same token, it would protect employee activity directed against such government action. Of course, not all "political" speech by employees can reasonably be characterized as activity "for mutual aid or protection" even under my expanded definition. For example, employees handing out "right-to-life" pamphlets or literature opposing military assistance to El Salvador would not generally come within this definition of "mutual aid or protection" under section 7.192 These issues do not affect any aspect of the employer's conduct, in labor relations or otherwise. ${ }^{193}$

191 Professors Fischl and Hyde have each argued effectively, albeit in different ways, for an expansion of $\S 7$ coverage to protect a broader range of political activity by employees. Professor Fischl demonstrates that concerted activity not grounded in "self-interest" but motivated by support for the interests of other employees should itself be protected by $\S 7$. See Fischl, supra note 21, at $842-58$. Professor Hyde notes the vast and growing significance of public regulation for conditions of private employment, and primarily on that basis argues for broader protection of political means of seeking improvements in conditions of employment. See Hyde, supra note 21, at 13-19. I agree with both of them, but my concern is somewhat different. I am seeking to broaden the definition of what interests employees have so as to gain $\S 7$ protection for conventional as well as "political activity" on their own behalf, and for solidaristic activity on their behalf by other employees.

192 Nor, it seems, would the employees in the Eagle Electric or Tektronix cases discussed supra note 83 .

193 Surely an argument might be proffered, based upon some comprehensive ideological or religious world view, that employers are affected and that employees' interests as employees are deeply implicated by these issues (and by almost any issues 
One can surely imagine some protests that come within the proposed definition but that seem so remote from the interests of employees that the statute cannot reasonably be construed to protect them. Such an exercise in imagination should not distract from the reality that concerted activity is unlikely in the absence of some shared sense of concern among employees. ${ }^{194}$ As I will explain below, the requirement of "concerted activity" operates both as an acceptable limit on the consequences of expanded subjectmatter coverage and as concrete evidence of the existence of employee concern over a subject. The fact of concerted activity, and not an artificially restricted conception of the appropriate concerns of employees, should be the fulcrum of section 7 analysis.

\section{B. "Concerted Activity" as an Alternative Gauge of Employee Concerns}

The redefinition of section 7 proposed here is driven by a simple idea: by directing their energies toward a particular area of concern, employees themselves define their own interests and thus the proper objects of "mutual aid or protection." The presence of concerted activity, an independent requirement for section 7 protection under current doctrine, thus serves to indicate the existence of genuine employee concern over an issue.

The prevailing interpretation of the "concert" requirement is quite literal. ${ }^{195}$ In most cases it is fulfilled if and only if some

of importance to the speaker). But the argument would sound implausible and contrived to all but the converted, and would almost invariably depend on post hoc rationalizations about speech that on its face makes no reference to the employer or to the shared interests or experiences of employees. Nor could political speech of this sort be brought within the scope of $\S 7$ by including a request that the employer support such a cause. In contrast, in the case of employee protest of employer's political activity and contributions, the employer has opened itself up to a broader range of employee protest by expanding its own activities into the political sphere.

194 This may not be true of tactical product criticism of the sort illustrated in Jefferson Standard. For my contentions in support of protecting this kind of criticism, see infra text accompanying notes 234-45.

195 See Meyers Industries, Inc. (Meyers II), 281 N.L.R.B. 882 (1986), enforced sub nom. Prill v. NLRB, 835 F.2d 1481 (D.C. Cir. 1987). A fuller elaboration of the reasoning behind the Board's approach to the concert requirement may be found in the Board's original decision in this case, Meyers Industries, Inc. (Meyers I), 268 N.L.R.B. 493 (1984), remanded sub nom. Prill v. NLRB, 755 F.2d 941 (D.C. Cir.), cert. denied, 474 U.S. 948 (1985). After the court of appeals remanded Meyers I for Board reconsideration in light of the Supreme Court's decision in NLRB v. City Disposal Systems, 465 U.S. 822 (1984), see infra note 197, the Board reaffirmed its earlier decision but underscored its willingness to recognize various ways in which individual 
activity is undertaken by two or more employees together. ${ }^{196}$ The activity of a single individual will be deemed "concerted" if it is undertaken after consultation with and at the behest of others, or with the object of inducing or preparing for group action, or pursuant to rights contained in a collective bargaining agreement. ${ }^{197}$ One employee's solitary complaint about her own working conditions will not generally be protected. ${ }^{198}$ Nor, under my proposal, would an individual's complaint about product safety be protected unless it was undertaken as part of, or with an eye toward, joint action with other employees.

In embracing the existing contours of the "concert" requirement, this proposal runs against the current of recent commentary. Some observers, most notably Professors Robert Gorman and Matthew Finkin, have called for virtual elimination of the requirement. ${ }^{199}$ They acknowledge that a literal reading of section 7 suggests that individual action is not generally protected unless undertaken in "concert" with other employees, but nonetheless argue that Congress did not intend such a limitation. ${ }^{200}$ They

activity might be linked to group activity so as to come within $\S 7$. See Meyers $I I, 281$ N.L.R.B. at 885-87.

196 See Meyers I, 268 N.L.R.B at $493-94$.

197 See City Disposal Systems, 465 U.S. at 831; Meyers II, 281 N.L.R.B. at 885-87. In City Disposal the Supreme Court upheld the Board's Interboro doctrine, see Interboro Contractors, Inc., 157 N.L.R.B. 1295, 1298 (1966), enforced, 388 F.2d 495 (2d. Cir. 1967), which held that individual assertion of a right contained in a collective bargaining agreement constituted "concerted activity" within the meaning of $\$ 7$ because of the act's close tie to the collective activity that led to the agreement. See City Disposal, 465 U.S. at 831-32, 841.

198 See Meyers I, 268 N.L.R.B. at 494; see, e.g., Capitol Ornamental Concrete Specialties, Inc., 248 N.L.R.B. 851 (1980) (holding that purely personal "griping" is not protected).

${ }^{199}$ See Gorman \& Finkin, supra note 110, at 329; see also B. Glenn George, Divided We Stand: Concerted Activity and the Maturing of the NLRA, 56 GEO. WASH. L. REV. 509,511 (1988) (calling for the elimination of the concert requirement); Staughton Lynd, Communal Rights, 62 TEX. L. REv. 1417, 1426-30 (1984) (to the same effect); $c f$. Terry A. Bethel, Constructive Concerted Activity Under the NLRA: Conflicting Signals from the Court and the Board, 59 IND. L.J. 583, 606-13 (1984) (advocating more flexible concept of concerted action).

${ }^{200}$ See Gorman \& Finkin, supra note 110, at 299. Professors Gorman and Finkin point out that Congress borrowed the phrase "concerted activities for mutual aid or protection" from $\S 2$ of the Norris-LaGuardia Act, ch. 90, 47 Stat. 70, 70 (1932) (codified at 29 U.S.C. $\$ 102(1988)$ ), which sharply restricted the federal courts' injunctive powers in labor disputes. See Gorman \& Finkin, supra note 110, at 331. They argue that the insertion of the term "concerted" in that statute was designed not to single out group activity for exclusive protection, but rather to underscore Congress's rejection of decades of antilabor jurisprudence that had done the opposite: singled out concerted employee action for judicial condemnation. See id. 
further contend that this liceral reading, by leaving unprotected individual efforts to improve working conditions for all, yields anomalous results that are inconsistent with the basic policies of the Act. ${ }^{201}$ Professors Gorman and Finkin would essentially collapse the "concert" requirement into the requirement of "mutual aid or protection": where an individual's activity is directed to improving working conditions-that is, where its objective meets the existing definition of "mutual aid or protection"-it would be protected under section 7 whether undertaken by a lone individual or a group. ${ }^{202}$

The proposals for eliminating the "concert" requirement approve and extend the Board's now-abandoned doctrine of "constructive concerted activity." ${ }^{203}$ Under that approach to section 7, which culminated in the Board's decision in Alleluia Cushion Co., ${ }^{204}$ the Board protected the activity of a solitary employee who addressed "matters of great and continuing concern for all within the work force, ${ }^{205}$ such as job safety. This approach to section 7-what Professor Fischl calls the "conflationist strategy" of Alleluia Cushion ${ }^{206}$-was almost universally rejected by the courts of appeals, based largely on the literalist objection that it renders part of section 7's sparse language redundant. ${ }^{207}$

at 331-37. From the early labor conspiracy cases through the antitrust attack on labor under the Sherman and Clayton Acts, courts had condemned employee actions taken in "combination" that would be admittedly immune from legal attack if taken individually, such as quitting employment or refusing to purchase nonunion goods. Professors Gorman and Finkin are very persuasive in their argument that the congressional sanctioning of "concerted activities for mutual aid or protection" in the context of the Norris-LaGuardia Act was based on the understanding that individual action was already largely immune from injunction. See id. at 336.

The argument loses some force however, when applied to $\$ 7$ of the NLRA. See Bethel, supra note 199, at 600-02. In the context of employer action against dissenting workers, toward which $\S 7$ is primarily directed, there is no similar history of special legal immunity for individual action. Prior to the enactment of the Wagner Act in 1935, employers were free to discharge an employee for any reason at all, including individual or group protest of working conditions. Id. Congress might well have imported the term without reflecting on its altered significance in this new context. See supra text accompanying notes 110-16. But Congress could not have proceeded on the understanding that individual protest was already protected from employer retaliation (as they could have with respect to judicial suppression). See Bethel, supra note 199 , at $600-02$.

201 See Gorman \& Finkin, supra note 110, at 329.

202 See id. at 344-45.

203 See id. at $299,308$.

204221 N.L.R.B. 999 (1975).

$205 \mathrm{Id}$. at 1000.

206 Fischl, supra note 21, at 828.

207 See Fischl, supra note 21, at 828-29; Gorman \& Finkin, supra note 110, at 315- 
Ultimately accepting this criticism, the Board overturned Alleluia Cushion. ${ }^{208}$

The literal language of section 7 presents a serious hurdle, though not an insurmountable one, to any attempt to eliminate the "concert" requirement. ${ }^{209}$ In my view, however, the more serious objection to Alleluia Cushion or to any similar attempt to eliminate the "concert" requirement is that it rests upon an externally imposed definition of the interests of employees. Under Alleluia Cushion, section 7 protection turned entirely upon whether the Board found that the employee's objective was a matter of "great and continuing concern for all within the work force. ${ }^{210}$ As the Board explained in Meyers I:

The practical effect of [Alleluia Cushion] was to transform concerted activity into a mirror image of itself. Instead of looking at the observable evidence of group action to see what men and women ... in fact chose as an issue about which to take some action, it was the Board that determined the existence of an issue about which employees ought to have a group concern. ${ }^{211}$

I concur with the Board's prevailing view: Collective action among workers is distinctive; it is generally the best evidence we have of what employees actually care about in the workplace.

But the Board's acknowledgment that joint action is the best evidence of shared concern undermines its current limitations on the scope of employee interests under section 7. In the interests of promoting employees' own vision of what matters to them at work, employee activity that is concerted in nature should be presumed to be for "mutual aid or protection." 212 We should, in the Board's words, "look[] at the observable evidence of group action to see what men and women in the workplace in fact chose as an issue about which to take some action," ${ }^{213}$ but we should do so not only to deny protection in the absence of joint action but also to grant protection where employees, by engaging in joint action, have expressed their shared concern about non-traditional issues.

28.

${ }^{208}$ See Meyers Indus., Inc. (Meyers I), 268 N.L.R.B. 493 (1984).

209 See supra note 200.

210 Alleluia Cushion Co., 221 N.L.R.B. at 1000.

211 Meyers I, 268 N.L.R.B. at 495.

212 Such presumption should be subject only to the qualifications discussed in the foregoing section. See supra text accompanying notes 190-94.

213 Mejers I, 268 N.L.R.B. at 495. 
The proposed approach to section 7 would minimize the role of the Board and the courts in assessing the appropriateness of the employee's aims and concerns, and focus their attention instead on whether the employees themselves defined their concerns as the appropriate focus of joint activity. Protection would thus turn on fairly objective (if sometimes admittedly fortuitous) circumstances rather than on highly contestable, policy-laden views about the proper interests of employees.

The employees who fail to surmount the existing concert requirement-individuals fired for refusing to drive an unsafe vehicle, or for protesting onerous working conditions affecting allare sympathetic complainants. Their actions may indeed represent the early manifestations of employee dissent and thus the roots of concerted activity. The section 7 requirement that activity be concerted in nature is not without its costs. But in my view the cost would be justified, even if not strictly compelled by the language of the Act, if it were to permit us to place in the hands of employees themselves the choice of which issues and concerns are truly important in the pursuit of "mutual aid or protection."

\section{Other Legal and Practical Limits on the Consequences of the Proposed Expansion of Section 7 Rights}

One might imagine that recognizing the presumptive legitimacy of employee protest about many aspects of the employer's business would subject employers to a rash of damaging public disclosures on all aspects of their operations, or even to strikes and picketing aimed at forcing the employer to alter its policies. Whether this would be a desirable or an undesirable consequence, it is a highly unlikely one. Even apart from the development of specific exceptions for certain kinds of public criticism or disclosure, various aspects of existing law greatly restrict the likely consequences of broadening section 7 rights as proposed here.

Section 7 protects concerted activity for mutual aid or protection; but it does not protect all such activity. ${ }^{214}$ First, section 7 protects only those who are defined as "employees" under the Act; supervisory, "confidential," and managerial employees do not come

214 Indeed, as Karl Klare has pointed out, "[i]t is extraordinary how much of the law ... pertains to ways in which employees may lose rather than gain $\S 7$ rights." Klare, supra note 169, at 1403 n.196; see also id. at 1403-05; ATLESON, supra note 40, at 44-66. 
within this definition. ${ }^{215}$ Thus; many of those employees whose dissent would be viewed most anxiously by employers have no rights under section 7.

Moreover, section 7 rights are subject to restrictions on the time and place of their exercise-activity occurring in work areas and during work hours may be curtailed by the employer ${ }^{216}$-as well as on their manner. ${ }^{217}$ Of particular importance in the present context is the withdrawal of protection for speech that is knowingly or recklessly false and defamatory. ${ }^{218}$ "Product disparagement," revelation of environmental crimes or the like would not be protected if it was false and the employees acted with knowledge or reckless disregard of its falsity. ${ }^{219}$

215 See 29 U.S.C. § 152(11) (1988) (supervisory exclusion); NLRB v. Hendricks County Rural Elec. Membership Corp., 454 U.S. 170, 180-81 (1981) (affirming the Board's limitation of "confidential" to include only those who "act in a confidential capacity to persons who exercise "managerial" functions in the field of labor relations" (quoting Ford Motor Co., 66 N.L.R.B. 1317, 1322 (1946))); NLRB v. Bell Aerospace Co., 416 U.S. 267 (1974) (managerial exclusion). Also, the Act protects only "employees" of those who qualify as "employers" within the meaning of the Act, 29 U.S.C. § 152(2) (1988). See supra note 9.

${ }^{216}$ See Republic Aviation Corp. v. NLRB, 324 U.S. 798, 797-98 (1945) (holding that employees had a $\$ 7$ right to solicit union support at the workplace subject to the employer's power to restrict such activity to non-working areas and non-working times).

${ }^{217}$ For example, physical violence or threats, sabotage, and prolonged physical occupation of the employer's property are unlawful under laws of general application and are unprotected under long-established interpretations of $\$ 7$. See, e.g., NLRB v. Fansteel Metallurgical Corp., 306 U.S. 240, 256 (1939) (holding that a prolonged sitdown strike involving the destruction of machinery was unprotected); NLRB v. Thayer Co., 213 F.2d 748, 755-56 (1st Cir. 1954) (holding that picketing that restrains or coerces other employees in the exercise of their $\$ 7$ rights is unprotected); see also infra text accompanying notes 278-81. Other forms of concerted activity that are not otherwise unlawful, such as slowdowns, have long been held unprotected. See Elk Lumber Co., 91 N.L.R.B. 333, 336 (1950). Numerous scholars have criticized the exclusion of slowdowns and partial strikes from the scope of $\S 7$. See, e.g., ATLESON, supra note 40, at 50-66 (rebutting common arguments in favor of the unprotected status of slowdowns and partial strikes); Julius G. Getman, The Protected Status of Partial Strikes After Lodge 76: A Comment, 29 STAN. L. REv. 205, 206 (1977) (concluding that the unprotected status of partial strikes is "inconsistent with the trend of decisions construing sections 7 and $8^{n}$ (footnotes omitted)). Indeed, the unprotected status of these activities is arguably open to question after more recent decisions. See Lodge 76, Int'l Ass'n of Machinists v. Wisconsin Emp. Rel. Comm'n., 427 U.S. 132 (1976); NLRB v. Insurance Agents' Int'l Union, 361 U.S. 477 (1960). See generally Getman, supra, at 207 (stating that the Court's decision in Insurance Agents "undermined the reasoning on which Briggs $\mathcal{E}$ ' Stratton rested").

218 See Linn v. United Plant Guard Workers, Local 114, 383 U.S. 53, 63 (1966) (emphasizing that "malicious libel enjoys no constitutional protection in any context").

219 Indeed, in those cases the speech would be actionable under state defamation law. See id. at 59-63. 
Concerted activity that takes the form of economic pressureespecially strikes and picketing-is further limited by collective bargaining obligations, both contractual and statutory. Most work stoppages during the term of a collective bargaining agreement violate the ubiquitous no-strike clause and, under well-established case law, are therefore unprotected by section 7.220 The duty to bargain in good faith under the Act has been interpreted as placing further limitations on the scope of section 7 rights, and thus on the consequences of expanding those rights. That duty extends by statute only to "terms and conditions of employment," 221 and has been further limited by judicial decision to the sphere of "mandatory topics of bargaining. ${ }^{n 222}$ This has important consequences for the scope of section 7 rights, for the duty to bargain in good faith over mandatory topics has been held to imply the corollary duty not to engage in "economic pressure" such as strikes or boycotts in support of nonmandatory or "permissive" topics, at least in the context of collective bargaining over mandatory topics. ${ }^{223}$ Thus, employees' use of economic pressure to gain concessions from the employer in collective bargaining would remain largely limited, even under my proposed broader reading of section 7, to "terms and conditions of employment" as that term has been construed over the years. ${ }^{224}$

${ }^{220}$ See NLRB v. Sands Mfg. Co., 306 U.S. 332, 344 (1939) (holding that activities in breach of contract are unprotected under $\$ 7$ ).

221 NLRA § 8(d), 29 U.S.C. § 158(d) (1988).

222 See NLRB v. Wooster Div. of Borg-Warner Corp., 356 U.S. 342 (1958).

${ }^{223}$ See id. Under Borg-Warner, a union commits an unfair labor practice under $\S 8(b)(3)$ of the Act, and employees engage in unprotected activity under $\S 7$, by conditioning their agreement on mandatory issues upon the employers' concessions on nonmandatory issues. Borg-Warner is frequently read more broadly to prohibit, and to deny $\$ 7$ protection to economic pressure in support of nonmandatory demands under any circumstances. See COX ET AL., supra note 12, at 547; ROBERT A. GORMAN, LABOR LAW: UNIONIZATION AND COLLECTIVE BARGAINING 303 (1976). But that broader proposition is not supported by its supposed rationale-that such conduct constitutes a refusal to bargain on mandatory topics. See Theodore J. St. Antoine, Legal Barriers to Worker Participation in Management Decision Making, 58 TuL. L. REv. 1301, 1305-07 (1984); cf. Pope, supra note 56, at 957 (questioning this broader reading of Borg-Warner). Simply because the Act does not legally compel the employer to bargain over such matters does not lead to the conclusion that employees may not bring economic pressure on the employer to do so. Thus, a work stoppage aimed at pressuring the employer to reverse a partial shutdown decision, a nonmandatory topic under First Nat'1 Maint. Corp. v. NLRB, 452 U.S. 666 (1981), or a work stoppage to improve product quality, valid under the proposal, should be protected under $\$ 7$ unless it effectively precludes bargaining on other "mandatory" issues.

${ }^{224}$ Of course, limitations on the duty to bargain, like the limits on $\S 7$ rights, rest 
Without approving all these limits on employee rights, ${ }^{225}$ one must acknowledge their existence, for they greatly restrict the consequences of the proposed change. Still, I do not wish to understate those consequences. A broader definition of the interests of employees under section 7 would expose the employer to some disruptive tactics-work stoppages and the like-with respect to a far broader range of topics than before. The strike is presumptively a protected form of protest under section 7 absent particular circumstances such as those noted above. 226

But the consequences of broadening protection are further limited by the lawful countermeasures available to employers. Under current law employees engaged in a lawful, protected strike may be "permanently replaced," though not fired, without any showing of economic necessity. ${ }^{227}$ Partly as a consequence of this much-criticized quirk of American labor law, ${ }^{228}$ as well as unfavor-

on a narrow conception of the legitimate interests of employees, and a broad conception of the scope of managerial prerogatives entitled to recognition under the Act, both of which I challenge here. See supra notes 125-65 and accompanying text; infra notes 284-302 and accompanying text. Acceptance of the arguments advanced here for expanding the employee interests protected by $\$ 7$ would deeply erode the conceptual foundations of the limits on the mandatory duty to bargain: Still, the duty to bargain is defined by a different and narrower statutory provision, and raises practical and legal considerations that go beyond those considered here.

225 See supra note 217.

226 See NLRA § 13, 29 U.S.C. § 163 (1988) ("Nothing in this Act, except as specifically provided for herein, shall be construed so as either to interfere with or impede or diminish in any way the right to strike ...."); NLRB v. Washington Aluminum Co., 370 U.S. 9 (1962). Various circumstances can render a strike unprotected-an unlawful objective, an attempt to force employer concessions on permissive topics of bargaining, or a breach of a contractual no-strike promise-but strikes in support of interests recognized by $\S 7$ are presumptively protected.

${ }^{227}$ See NLRB v. Mackay Radio \& Tel. Co., 304 U.S. 333, 345-46 (1938). Employees striking in response to employer unfair labor practices may not be permanently replaced. See Mastro Plastics Corp. v. NLRB, 350 U.S. 270 (1956). Despite contemporary criticism, see infra notes 228-29 and accompanying text, the Mackay rule, permitting permanent replacement of economic strikers, was reaffirmed and extended in Trans World Airlines v. Independent Fed. of Flight Attendants, 489 U.S. 426 (1989).

${ }^{228}$ Most industrial democracies forbid the hiring of permanent replacements for strikers. See Matthew W. Finkin, Labor Policy and the Enervation of the Economic Strike, 1990 U. ILL. L. REV. 547, 569. Criticism of Mackay, on grounds of both its conceptual inconsistency with and its practical impact on the statutory right to strike, has been a recurrent theme in labor law scholarship with which I happily associate myself. See ATLESON, supra note 40, at 19-34; WEILER, supra note 8, at 265-69; Leonard B. Boudin, Rights of Strikers, 35 U. ILL. L. REV. 817, 830 (1940); Finkin, supra, at 567-74; Getman, supra note 20, at 1203-05; Klare, supra note 169, at 301-03; George Schatzki, Some Observations and Suggestions Concerning a Misnomer-"Protected" Concerted Activities, 47 TEx. L. REv. 378, 382-95 (1969); Paul Weiler, Striking A New Balance: Freedom of 
able economic conditions and a variety of nonlegal constraints, the strike is at risk of becoming a virtual anachronism in modern labor relations. $^{229}$ The notion that employees, once freed to protest patient conditions and product quality, will launch a rash of strikes over such matters is simply fanciful.

This raises a more general observation about the consequences of broadening the scope of the issues as to which section 7 offers protection: those consequences will be most drastically limited not by what the law allows workers to do but by what workers realistically will choose to do. First, as I have shown above, employees tend to share with their employers a strong interest-psychological as well as economic-in public and consumer approval of the employer and its product or service. Moreover, employees who go so far as to contemplate public criticism or other protest directed at their employer do not face a cost-free choice. The employer faced with what it regards as hostile worker activity retains the power, even if not the legal right, to fire the employee. That is, of course, precisely what the statute prohibits, but long experience under the NLRA teaches that the fact that employer retaliation is unlawful does not make it unlikely. The well-documented prevalence of employer discrimination based on union activity, clearly prohibited by section $8(a)(3)$ of the Act, is powerful evidence to this effect. ${ }^{230}$

Contract and the Prospects for Union Representation, 98 HARV. L. REV. 351, 388-94 (1984); Julius G. Getman, The Strike at Jay: The Evil of Mackay (1991) (unpublished manuscript, on file with author) [hereinafter The Strike at Jay]. But see David Westfall, Striker Replacements and Employee Freedom of Choice, 7 LAB. LAW. 137 (1991) (defending the Mackay doctrine).

${ }^{229}$ See Finkin, supra note 228, at 567-69. The long-overdue statutory reversal of Mackay is currently under consideration by Congress. See H.R. 5, 102d Cong., 1st Sess. (1991) (prohibiting permanent replacement of strikers); S. 55, 102d Cong., 1st Sess. (1991) (amending NLRA and Railway Labor Act to prevent discrimination based on participation in labor disputes). Both bills would add permanent replacement of strikers to the list of employer unfair labor practices, but only in the unionized workplace, leaving employers free to permanently replace unorganized workers who walk off the job in protest.

230 See Michael H. Gottesman, Rethinking Labor Law Preemption: State Laws Facilitating Unionization, 7 YALE J. REG. 355, 363-65 (1990); Paul C. Weiler, Promises to Keep: Securing Workers' Rights to Self-Organization Under the NLRA, 96 HARV. L. REV. 1769, 1778-81 (1983) [hereinafter Weiler, Promises]. Professsor Weiler's conclusions about the prevalence of anti-union discharges were questioned in Robert J. LaLonde \& Bernard D. Meltzer, Hard Times for Unions: Another Look at the Significance of Employer Illegalities, 58 U. CHI. L. REV. 953 (1991). But see Professor Weiler's response, Paul C. Weiler, Hard Times for Unions: Challenging Times for Scholars, $58 \mathrm{U}$. CH. L. REV. 1015 (1991), arguing that Professors Lalonde and Meltzer had misconstrued his conclusions, misinterpreted the data, and misunderstood the significance of the widespread employer illegality that they themselves found. 
The employer's ownership of the enterprise and of the premises gives it the power to fire workers and to eject them from the workplace, even in the face of a federal statutory prohibition, subject only to whatever remedies or penalties the law provides after the fact. ${ }^{231}$ The worst that can befall an employer who is found to have unlawfully fired a worker for engaging in protected concerted activity is an order some years after the event to reinstate the worker (if she still wants the job) and to make her whole for any back pay actually lost, after subtracting other earnings. ${ }^{232}$ An employer who calculates the likely cost of an eventual finding of liability, discounted by its probability and the delay in its implementation, may well decide that the benefits of ridding the organization of the offending employee vastly outweigh the costs. ${ }^{233}$ The typical employee, for her part, is capable of making the same rough calculation, and is likely to be deterred except under quite unusual circumstances.

To some extent, then, the consequences of expanding the range of permissible subjects of concerted activity under section 7 protection are limited by what $I$ believe to be unwarranted restrictions of the rights of employees and by the woeful inadequacy of the Board's administrative enforcement scheme. But even if enforcement mechanisms were reasonably effective, the substantial risk of even temporary job loss is not something that employees are likely to court on a whim. They must be highly motivated to undertake what they surely, and often correctly, believe to be a substantial risk of employer retaliation in some form. Fear of job loss and the difficulty and delay that face an employee seeking to enforce her legal rights are, at least as to unorganized employees, likely to deter the vast bulk of criticism just as they deter union activity. Indeed, the deterrence is likely to be even greater as to "altruistic" criticism than as to union organizing, the protected status of which has been established for 50 years, and which at least carries the eventual prospect of economic rewards.

${ }^{231}$ In the case of the NLRA, disregard of the Act is encouraged by long delays in the enforcement process (four to eight years from discharge to enforcement of a reinstatement order is not uncommon), see Weiler, supra note 230, at 1795-97, and the lack of punitive sanctions or even fully compensatory relief. See id. at 1787-93.

232 See Pennsylvania Greyhound Lines, 1 N.L.R.B. 1, 51 (1935).

233 See generally Gottesman, supra note 230, at 363-64 (considering the deterrent effect of employer resistance and retaliation on union activity); Weiler, Promises, supra note 230, at 1787-97 (discussing the willingness of employers to commit unfair labor practices because of the inherent weakness of the NLRA's remedy structure). 
In sum, the extent of employee protest is greatly restricted by independent limitations embedded in the labor laws as well as by the realities of the employment relationship. For better or worse, there is no reason to believe that broadened section 7 protection will yield an outpouring of employee speech or other protest on issues of public consequence.

\section{What Remains of "Product Disparagement"?}

Existing law greatly limits the additional protection that would be afforded by the proposal. On the other hand, the broad definition of "mutual aid or protection" proposed here would clearly undermine the foundations of the "product disparagement" doctrine of Jefferson Standard: it could no longer be said that the subject matter of such activity was not within the proper purview of employee concerns. But there might yet remain arguments for withholding protection from some product disparagement. I consider and reject below the argument for denying protection to tactical product criticism of the sort illustrated in Jefferson Standardin which criticism of the employer's product is used as a device for advancing unrelated and undisclosed economic objectives. But I concede the existence of other circumstances in which product criticism might remain outside the scope of an expanded section 7 .

\section{Tactical Criticism of the Employer or its Product}

The tactical use of public criticism of the employer and its product to achieve economic aims presents perhaps the least appealing case for expanding section 7 protection. The case for recognizing the broader interests of employees is surely weaker here, in that the employees may not in fact be interested in the subject of their communication, but only in its utility in pressuring the employer to make economic concessions. Moreover, employers may see the greatest threat of product or other criticism as coming from employees who are motivated not by concern about the subject of their public disclosure but by traditional economic objectives. Permitting a broader range of protest on subjects of public interest might seem to vastly increase employee leverage in support of traditional economic demands. ${ }^{234}$ Yet I do not believe these

${ }^{234}$ This possibility would be limited by existing doctrine prohibiting unions' insistence on, and use of economic pressure in support of, nonmandatory demands as a condition for agreement on mandatory topics. See supra text accompanying notes 
circumstances call for the denial of section 7 protection to this activity.

In general it is held not to be the province of the Board or the courts to attempt to calibrate the balance of economic weaponry. ${ }^{235}$ To that extent this objection to broader section 7 coverage is misdirected. ${ }^{236}$ Indeed, given the enormous advantages that employers have in their contest with labor under current law and economic conditions, ${ }^{237}$ a mandate to adjust the balance could more plausibly be turned around to support broader protection of employee criticism of the employer.

Objections to the purely tactical use of product disparagement and other "public-oriented" criticism of the employer of the sort illustrated by Jefferson Standard may reflect as well a fear that the public may be unfairly duped into supporting labor's cause. As the Supreme Court stated in Jefferson Standard, "[a] disclosure of [the economic] motive might have lost more public support for the employees than it would have gained, for it would have given the handbill more the character of coercion than of collective bargaining." 238

Denial of section 7 protection is not an appropriate response to this problem. My central claim is that product quality and other aspects of the employer's conduct are themselves legitimate objects of employee concern. If that claim is accepted, it would be anomalous to deny protection to such criticism on the ground that the criticism is actually motivated by the employees' desire to achieve improvements in wages and working conditions-objectives that lie at the core of the Act. ${ }^{239}$ It makes little sense to deny

220-24.

235 See, e.g., American Shipbuilding Co. v. NLRB, 380 U.S. 300, 317 (1965) (holding that the statute does not confer on the Board a "general authority to assess the relative economic power of the adversaries in the bargaining process and to deny weapons to one party or the other because of its assessment of that party's bargaining power").

236 See Getman, supra note 20, at 1239.

237 See Weiler, supra note 228, at 358-63; The Strike at Jay, supra note 228. For further discussion of the significance of employer countermeasures in assessing the consequences of this proposal, see supra text accompanying notes 227-29.

${ }^{238}$ NLRB v. Local Union 1229, IBEW, 346 U.S. 464, 477 (1953).

${ }^{239}$ Even in Jefferson Standard the Court acknowledged that the existence of a traditional economic objective potentially strengthened the employees' claim to $\$ 7$ protection. The Court took it as self-evident that the leaflet would have been unprotected absent this employee dispute, then added that the existence of the dispute afforded the employees "no substantial defense." Id. at 476-77. 
protection to otherwise-protected conduct on the basis of an otherwise-protected motive.

There are additional reasons for not excluding this kind of "tactical" product criticism from protection. To make the sincerity of employees' expressed concerns decisive would raise troubling issues of proof and introduce great uncertainty about the scope of protection. Moreover, and perhaps more to the point of employer concerns, protecting "tactical" product criticism seems unlikely to increase its prevalence substantially, for this sort of activity will be undertaken, generally speaking, only by employees who are already organized and engaged in collective bargaining. Those employees are already relatively well-situated to circumvent the proscription against product disparagement if they are so inclined. Recall that under current law employees can quite readily gain protection for a broad range of public criticism of the employer where it is made in connection with a traditional labor dispute: simple disclosure of the employees' traditional economic objectives is usually sufficient to bring public criticism on other issues within the protection of the statute. ${ }^{240}$ Moreover, current limits on section 7 protection have little effect on truthful criticism or disclosures made by nonemployee agents or allies of the union, who cannot be discharged but can only be sued for defamation in limited circumstances.

Finally, if the impact of product criticism by employees is thought to be blunted by public knowledge of the existence of a labor dispute, it remains open for the employer to supply this information, as well as to respond to the substance of the criticism. Consequently, I see no compelling reason for withholding protection from concerted employee criticism of the employer's conduct or product on the ground that it is actually motivated by undisclosed economic objectives.

\section{Disclosure or Criticism that Contravenes Specific} Job Responsibilities

What about the sales representatives who personally criticize the product they must then try to sell? Or the public relations spokespersons who lambast the company environmental practices they are charged with defending? These employees may have violated the specific requirements of their job, and, the employer may argue, rendered themselves ineffective in that job for the future. Similarly,

${ }^{240}$ See supra text accompanying notes 67-74. 
the employees who reveal specific "trade secrets" entrusted to them-confidential, closely held information about the product or manufacturing process that would be useful to competitors-may violate very specific obligations to the employer. ${ }^{241}$

In the unusual case in which employees within the Act's protection engage in concerted activity of this sort, there may yet be an argument for withholding protection. To do so one would not need to assert a categorical limitation on the scope of employee concerns. Nor would one need to resort to generalized notions of employee loyalty or of managerial prerogatives, of the sort discussed below, to explain the nature of the employer's interest in proscribing the conduct. In these cases the employer's interest is stronger, and the employee's interest is arguably weaker, in light of the specific obligations violated by the employee. Exceptions to the scope of section 7 rendering some such conduct unprotected, and permitting discharge of employees who engage in it, are not necessarily incompatible with my fundamental premise that employees have a legitimate interest in all aspects of their employer's conduct and policies.

In working out the application of a broader definition of section 7 interests to particular fact situations, the Board and the courts will have to confront just the sort of issues it already confronts in many contexts under section 7: when does an employee's conduct, presumptively protected as concerted activity, nevertheless violate the legitimate rules of the workplace or the legitimate demands of the employer, so as to take it outside of section 7 protection? It has long been established, for example, that an employer may fire an employee who hands out union literature during working time, in violation of a nondiscriminatory, uniformly enforced company rule prohibiting such conduct. ${ }^{242}$ Similarly, employees who concertedly refuse to perform certain work assignments while remaining on the job, ${ }^{243}$ or who deliberately time a work stoppage so as to cause serious physical damage to the employer's property, ${ }^{244}$

241 That is, obligations more specific than the "duty of loyalty" invoked in Jefferson Standard. See infra notes 270-75 and accompanying text (discussing the common law duty of loyalty).

242 See Republic Aviation Corp. v. NLRB, 324 U.S. 793, 803-04 n.10 (1945).

243 See, e.g., NLRB v. Montgomery Ward \& Co., 157 F.2d 486 (8th Cir. 1946) (holding that a refusal to process orders from employer's plant in another city wherein the employees were on strike is unprotected); Elk Lumber Co., 91 N.L.R.B. 333,336 (1950) (holding that work slowdowns are unprotected).

244 See NLRB v. Marshall Car Wheel \& Foundry Co., 218 F.2d 409 (5th Cir. 1955). 
although literally engaged in "concerted activity for mutual aid or protection," may find themselves beyond the bounds set by judicial and administrative interpretation of section 7. Without accepting all of these sundry exceptions to the literal scope of section 7,245 or fully delineating the additional exceptions that might follow acceptance of the proposal, I do wish to make clear that broadening the scope of section 7 protection as I propose would not preclude the development of narrow exceptions that remove that protection under some circumstances. It would, however, lift an unjustified categorical restriction on the legitimate topics of employee protest under the Act.

\section{E. The Relationship Between Expanded Section 7 Coverage and State Remedies for Wrongful Discharge}

It is evident that the proposed expansion of section 7 coverage would overlap, to a far greater degree than under current law, with some existing (and emerging) state remedies for wrongful discharge. In particular, some private "whistleblowers" who have a remedy under state law would be afforded an additional remedy under section 7. This overlap raises two important questions: First, would the NLRA preempt these state remedies, substituting what for many employees would be a less satisfactory alternative under section $7 ?^{246}$ And second, why not simply leave these cases to the continuing development of state law remedies? Why bother to add a new layer of protection for conduct that is increasingly protected by state common law?

Federal preemption would be wholly inappropriate. First, no state remedy for wrongful discharge in this context could actually conflict with federal law; the NLRA does not protect any discharges but simply remains indifferent to those it does not prohibit. Moreover, the inquiry of a state court in a wrongful discharge suit

245 See supra note 217 (criticizing Elk Lumber).

246 Preemption is a concern because some wrongful discharge claims might be construed as calling for the regulation of conduct that is "arguably prohibited" by the Act: discharge of an employee for exercise of newly expanded $\$ 7$ rights. It would thus come within the expansive terms of "Garmon preemption." See San Diego Bldg. Trades Council v. Garmon, 359 U.S. 236, 245 (1959) (holding that when an activity is subject to the NLRA, both state and federal courts must defer to the exclusive competence of the NLRB). But these cases appear to fall within established exceptions to Garmon. See infra text accompanying notes 247-50. For a thoughtful reassessment of the appropriate scope of labor preemption doctrines, see Gottesman, supra note 230 , at $391-410$. 
would be entirely different from the inquiry under section 7. The former would typically be completely unconcerned with the existence of joint employee activity, for example, and would focus almost exclusively on an issue that is decidedly secondary under section 7: the public interest in hearing what the employee has to say. ${ }^{247}$ Finally, these state wrongful discharge cases represent the vindication of "clear mandates of public policy" in a particular state, making them especially inappropriate candidates for preemption. ${ }^{248}$ The state's determination of a wrongful discharge claim by an employee who might, given certain additional allegations, also state a claim under section 7 poses no risk of interfering with the NLRB's primary jurisdiction to administer national labor policy, or of upsetting the balance of power between employers and workers acting collectively to advance their own interests. ${ }^{249}$ There would be no basis for invoking preemption in this kind of case. ${ }^{250}$

This is important because workers who would otherwise have access to a state judicial remedy for wrongful discharge are quite

247 The very different focus of the state law inquiry and the would-be ULP inquiry contributed to the Court's creation of exceptions to Garmon for libel actions in Linn v. United Plant Guard Workers Local 114, 383 U.S. 53, 63 (1966), and for intentional infliction of emotional distress in Farmer v. United Brotherhood of Carpenters \& Joiners Local 25, 430 U.S. 290, 302-05 (1977).

248 Preemption is to be avoided where the state is indicating interests "deeply rooted in local feeling and responsibility." See Farmer, 430 U.S. at 296 (quoting Garmon, 359 U.S. at 244); Linn, 383 U.S. at 61 . This phrase seems tailor made for the public policy type of wrongful discharge cases.

249 The remote risk of interference with national labor policy was also critical in Farmer, 430 U.S. at 298, and Linn, 383 U.S. at 63.

${ }^{250}$ Professor Michael Gottesman proffers another more innovative response to the preemption argument: preemption should not apply to state regulation of activity that is arguably prohibited by the NLRA but that Congress has not regulated on a "continuum"-that is, "subjects where Congress regulated up to a point but was indifferent as to what happened beyond that point." Gottesman, supra note 230, at 359. Thus, Professor Gottesman argues that states should be permitted to prohibit the discharge of union activists: Congress has prohibited the discharge of union activists but has not granted any affirmative right to employers to discharge employees for other reasons. See id. at 395. (This is in contrast to picketing, which Congress has protected up to one point on a continuum and prohibited beyond that point. See id.) There is no risk in this context that additional state remedies for antiunion discharges will conflict with federal policy, for example, by defining the prohibited conduct more broadly and thereby infringing on protected conduct. While acceptance of Professor Gottesman's argument would fully dispel any preemption difficulties with my proposal as well, it goes further than I need to go. Because the state remedy at issue here-wrongful discharge for, in essence, whistleblowing-does not regulate collective bargaining or union organizing at all, and is grounded in clear and important state policy mandates, it should not be preempted under existing doctrine. 
likely to prefer it. ${ }^{251}$ The standard remedy for a wrongful discharge under state law is full compensation, and perhaps punitive damages, whereas the Board is empowered only to give reinstatement and backpay. ${ }^{252}$ Moreover, the plaintiff in a wrongful discharge suit may invoke a panoply of procedures-full discovery and elaborate judicial process-that are unavailable under the NLRA. ${ }^{258}$

But given all this, what is the point of creating an additional remedy under the NLRA for this kind of conduct? The point is, first, to recognize as a matter of national labor policy that employees themselves have a broader range of concerns than the law now holds. From a more practical perspective, the point is to create a broadly accessible, even if not wholly adequate, remedy for employer retaliation against concerted employee conduct in support of these concerns. Wrongful discharge law affords significant advantages to those few who can successfully invoke it; but that is few indeed. ${ }^{254}$ The substantive law is spotty, varying enormously and somewhat arbitrarily among different jurisdictions; only a fraction of the cases that my proposal would cover would meet the substantive strictures of wrongful discharge law in their respective state courts. ${ }^{255}$ Equally important is the high cost of litigation, which keeps the great majority of potential claims out of court

251 See id. at 370-72.

${ }^{252}$ See id., see also supra text accompanying note 232.

${ }^{253}$ See id. For these same reasons, I foresee little risk that the proposal would discourage or slow the continued development of state wrongful discharge law. Most of the pressure for that development comes out of cases involving individual whistleblowing conduct that would not be protected under $\$ 7$ because it was not "concerted" in nature.

254 For a comprehensive argument delineating the shortcomings of litigated wrongful discharge remedies, see WEILER, supra note 8, at 78-82.

${ }^{255}$ The "public policy" exception remains the rare exception to the presumption that employment is terminable "at will." It is often found inapplicable to cases involving termination for mere disclosure or criticism of wrongful conduct, as opposed to refusal to engage in wrongful conduct. See, e.g., Adler v. American Standard Corp., 830 F.2d 1303, 1304 (4th Cir. 1987) ("employment termination motivated by a desire to conceal wrongdoing [from] higher corporate officers does not violate Maryland's public policy"); Geary v. United States Steel Corp., 319 A.2d $174,178-80$ ( $\mathrm{Pa}$. 1974) (finding that salesman fired for complaining internally about safety and quality of product stated no public policy claim). The remedy also depends in most states on the existence of a "clear mandate of public policy," which may pose a serious hurdle. See, e.g., Pierce v. Ortho Pharmaceutical Corp., 417 A.2d 505, 514 (N.J. 1980) (holding that a doctor fired for refusing to work on development of drug she regarded as potentially dangerous stated no public policy claim; no "clear mandate of public policy" violated). 
simply because the claimants cannot attract competent counsel to prosecute them. ${ }^{256}$

Under the NLRA's administrative enforcement mechanism, the Board's General Counsel itself prosecutes cases deemed meritorious; the process costs the employee nothing. Inadequate though it is, the process affords a low-cost mechanism that is widely and uniformly available to employees who would have no chance of gaining a hearing on their claim in state court or otherwise. ${ }^{257}$ Although it is important that the state remedy is not foreclosed through preemption where it is available, it is also important to recognize that the state judicial remedies do not begin to address the claims of the great majority of workers who might benefit from the proposed change in section 7 law. The proposed expansion of section 7 coverage is likely to affect primarily small, unorganized groups of employees who are sufficiently concerned about an issue, be it patient welfare or environmental practices, to face the substantial risk of employer displeasure and retaliation. Organized workers, who are more likely to act with the benefit of legal advice, already have available to them means of publicizing their criticisms without running afoul of the limitations on section 7.258 It is often unorganized workers engaged in spontaneous protests who get caught outside the protective reach of section 7.259 Particularly as to these situations, the policies of section 7 , bolstered by the public interest in gaining this sort of information, presumptively support the employees' claim to protection.

\section{RECONGEIVING THE COUNTERVAILING INTERESTS OF EMPLOYERS:} The Duty of Loyalty and Managerial Prerogatives

The limited definition currently given the term "mutual aid or protection" reflects a lack of appreciation for the breadth of the interests that the employee's role in the production process can generate. But more is at work here: employer interests that compete with the rights of employees, to which the courts have

${ }^{256}$ See WEILER, supra note 8, at 81-82.

257 I acknowledge that, barring the commitment of additional resources for enforcement, the prosecution of these new cases might draw resources away from the already inadequate prosecution of more traditional ULPs, such as discharge of union activists. That would be extremely unfortunate, but it does not justify the retention of an inappropriate restriction on the recognized scope of employee concerns.

258 See supra note 74 and accompanying text.

259 Almost all of the cases discussed above in which $\$ 7$ coverage was denied involved nonunion workplaces. See supra text accompanying notes 82-92. 
historically been highly sensitive, have pushed the courts toward a limited conception of employee rights. In particular, the employer's interest in the loyalty of its employees and, more broadly, in the unfettered exercise of its "managerial prerogatives" outside the traditional field of labor relations seems to account in great measure for the resistance to a broader conception of employee interests. Those same interests are sure to be asserted against the change proposed in this Article. In this Section, I scrutinize these employer interests and their role in arriving at an appropriate definition of the scope of employee interests protected by section 7 .

\section{A. Employees' Duty of Loyalty as a Limitation on Section 7}

"Product disparagement" was held in Jefferson Standard to be "indefensible" and "disloyal." 260 We must therefore consider whether the umprotected stacus of criticism of the employer's operations outside the labor relations area is grounded in and justified by employees' duty of loyalty to their employer.

Where does this duty of loyalty come from? It cannot be located in any provision of the NLRA. The Court in Jefferson Standard located a duty of loyalty in section 10 (c) of the Act, ${ }^{261}$ added by the 1947 Taft-Hartley amendments, ${ }^{262}$ which prohibits the reinstatement of any employee fired for "just cause." On this reading, activity within the ambit of section 7 could nonetheless be lawful grounds for discharge if it was "disloyal" and therefore provided "just cause." 263 That construction of the Act would have had the effect, as the dissent pointed out, of substantially repealing section 7 , something Congress expressly declined to do in $1947,{ }^{264}$ and

260 The Court held that the employees' conduct manifested such detrimental disloyalty as to provide 'cause' for [the company's] refusal to continue in its employ the perpetrators of the attack. ... There is no more elemental cause for discharge of an employee than disloyalty to his employer. It is equally elemental that the Taft-Hartley Act seeks to strengthen, rather than to weaken, that cooperation, continuity of service and cordial contractual relation between employer and employee that is born of loyalty to their common enterprise.

NLRB v. Local Union 1229, IBEW (Jefferson Standard), 346 U.S. 464, 472 (1953) (footnote omitted).

${ }^{261}$ See 29 U.S.C. $\$ 160$ (c) (1988); Jefferson Standard, 346 U.S. at 472, 477-78.

262 See Labor Management Relations Act, ch. 120,61 Stat. 136 (1947) (codified at 29 U.S.C. $\$ \S 141-197)$.

263 See Jefferson Standard, 346 U.S. at 477-78.

${ }^{264}$ See id. at 479-80 (Frankfurter, J., dissenting); see also infra text accompanying notes $278-81$. 
was soon abandoned. ${ }^{265}$ Jefferson Standard now stands for the exclusion of certain "disloyal" conduct from the protection of section 7 itself. ${ }^{266}$ Detaching the duty of loyalty from the "just cause" language of section $10(c)$, though entirely proper, leaves it with no greater support in the express provisions of the NLRA than the public interest I posit in hearing employee criticism.

The duty of loyalty invoked in Jefferson Standard, as it now stands, seems to stem not from the Act itself but from legal rules predating the Act. ${ }^{267}$ Under the common law, the employment relationship is governed by a species of agency law that is still often referred to as the law of "master and servant." Under those common law principles employees have a general duty of loyalty toward their principal or employer: a duty to act in the interest of the employer and to refrain from damaging the employer's business. ${ }^{268}$ This general duty of loyalty encompasses an obligation not to publicly criticize the employer's product or service or to disclose potentially harmful information about the employer. ${ }^{269}$

Although the common law concept of disloyalty might seem to fit the employees' conduct at issue in Jefferson Standard, it does not adequately explain the limitations on employee interests that underlie the decision. First, the common law duty of loyalty would probably not bar internal criticism, which has been held unprotected under section 7 where it is insufficiently related to terms and conditions of employment. ${ }^{270}$ Moreover, even the common law recognized an overriding privilege under some circumstances to disclose information harmful to the employer in order to protect the interests of the employee or of others. ${ }^{271}$ The evolving law of

${ }^{265}$ See NLRB v. Washington Aluminum Co., 370 U.S. 9, 12-13 (1962). This development is set forth in Getman, supra note 20, at 1233-34.

266 See Getman, supra note 20, at 1238-40. That had been the Board's view in Jefferson Standard. See Jefferson Standard, 346 U.S. at 477-78.

267 See ATLESON, supra note 40, at 87-91.

268 See 59 AM. JUR. 2D Master and Servant \$ 97 (1970) ("An employer has the right to expect loyalty from his employees ...." (citation omitted)); 56 C.J.S. Master and Servant \$ 42a (1948) ("As a general proposition, any act of the servant which injures or has a tendency to injure his master's business, interests, or reputation will justify the dismissal of the servant."); id. $\S 42$ e ("One who . . . performs acts . . . disloyal to his employer commits a breach of an implied condition of the contract of employment which may warrant discharge." (citation omitted)).

269 See RESTATEMENT (SECOND) OF AGENCY \$ 395 (1958) (setting forth the duty not to reveal information acquired in the course of employment "to the injury of the principal").

270 See supra text accompanying notes 91-92.

271 Thus, the Restatement characterizes the duty of loyalty as a duty "not to act 
wrongful discharge effectively expands this privilege under the common law, ${ }^{272}$ while the First Amendment has made deep inroads on the duty of loyalty in the public sector. ${ }^{273}$ These developments in the law reflect an increasing willingness to override the traditional obligations of employees toward their employers when the public interest is at stake. Yet employee speech in the interest of the public continues to be held unprotected under section 7.274 If the duty of loyalty cited in Jefferson Standard emanates, as it seems to, from the common law of agency, then that duty in its current form is too narrow to account for the wholesale exclusion from section 7 of criticism of the employer and its product. $^{275}$

At least some of the conduct at issue, however, would surely constitute a violation of the common law duty of loyalty. But that is only the beginning of the matter, for the duty of loyalty, ground-

or speak disloyally in matters which are connected with his employment except in the protection of his own interests or those of others." RESTATEMENT (SECOND) OF AGENCY $\$ 387 \mathrm{cmt}$. b (1958) (emphasis added). As an illustration, the Restatement cites an employee of a life insurance company who "in good faith advocates legislation which would require a change in the policies issued by the company. [The employee] has violated no duty to [the company]." Id. illus. 3; see also id. $\$ 395 \mathrm{cmt}$. f (describing an agent's privilege to reveal information "in the protection of a superior interest of himself or of a third person," such as information that the principal is committing a crime). See generally Phillip I. Blumberg, Corporate Responsibility and the Employee's Duty of Loyalty and Obedience: A Preliminary Inquiry, 24 OKIA. L. REV. 279, 283-89 (1971) (discussing an employee's duties of obedience, loyalty, and confidentiality as they relate to proposals to protect private-sector "whistleblowing").

272 See generally Blumberg, supra note 271 , at $307-12$ (analyzing the possibility of further limitations on the employer's right of discharge).

${ }_{273}$ Pickering v. Board of Education, 391 U.S. 563 (1968), can be understood as holding that public employees' freedom of expression, including the freedom to criticize their employer's conduct, outweighs any general duty of loyalty that the employees owe to their employer. See Blumberg, supra note 271, at 300-07. Connick v. Myers, 461 U.S. 138 (1983), in limiting that freedom strictly to "matters of public concern," might then be seen as reinstating the employees' duty of loyalty beyond that core.

${ }_{274}$ Thus, for example, the nursing home employee in Autumn Manor, Inc., 268 N.L.R.B. 239 (1983) (discussed supra text accompanying note 90), fired for testifying about possible abuse of patients, would seem to come within the privilege for advancing the superior interests of others.

275 In fact, the "disloyalty" strain of Jefferson Standard may come into play only in a case like Jefferson Standard itself, in which the employees' objective-the advancement of undisclosed economic aims-is concededly within the realm of "mutual aid or protection." In the absence of such ulterior (and protected) motives, therc is no need to call upon the duty of loyalty to override $\$ 7$ rights because the employees' criticism is simply not within the "mutual aid or protection" clause. The question then remains: why is that so? The concept of managerial prerogatives, discussed below, suggests an answer. 
ed in state common law, at least arguably conflicts with the express federal statutory rights of employees under section 7 of the Act. How is the common law duty of loyalty to be reconciled with section 7 of the NLRA?

The idea of "disloyalty" could play any one of three conceptually distinct functions in the interpretation of the Act. First, it could represent a countervailing employer "right" that trumps section 7 . This view would make sense only if that common law right were of constitutional dimensions. ${ }^{276}$ But the conceptual foundations of such a claim, reminiscent of the Lochner era, were swept away to make room for the New Deal and, particularly, the Wagner Act itself. ${ }^{277}$ The argument that section 7 cannot sanction disloyal conduct, and is overridden to the extent it does, is a throwback, long discarded and superseded by contemporary legal theory and social realities.

An alternative understanding of the meaning of disloyalty under the statute is as a residual employer "right"-one that simply fills the space left untouched by section 7 . On that view the employer has a right to the loyalty of its employees, and to freedom from criticism, but only as to matters beyond the scope of section 7 . Disloyal conduct, like tardiness or absenteeism, would be among the many grounds as to which the employer retains unconstrained discretion to fire or otherwise discipline employees. There is nothing strictly illogical in this view, but it would render the concept of disloyalty completely gratuitous in the interpretation of

${ }^{276}$ Given the conception of "property" that existed in that era, such an argument would not have been far-fetched. The federal courts in the late nineteenth and early twentieth centuries developed a broad notion of "property" as encompassing the right to do business, to seek customers and to hire workers free from outside interference. See Forbath, supra note 123, at 1169-72; Haggai Hurvitz, American Labor Law and the Doctrine of Entrepreneurial Property Rights: Boycotts, Courts, and the Juridical Reorientation of 1886-1895, 8 INDUS. REL. L.J. 307, 308-09 (1986). This expanded conception of employers' property rights became the foundation both for enjoining strikes and boycotts, see Hurvitz, supra at 339-44, and for invalidating pro-labor legislation, primarily under the Due Process Clause. See, e.g., Truax v. Corrigan, 257 U.S. 312 (1921) (invalidating state law restricting the use of injunctions in labor disputes); Coppage v. Kansas, 236 U.S. 1 (1915) (invalidating law prohibiting yellow dog contracts).

${ }^{277}$ See NLRB v. Jones \& Laughlin Steel, 301 U.S. 1 (1937); West Coast Hotel Co. v. Parrish, 300 U.S. 379 (1937). For an elegant exposition of the meaning of the 1937 cases, see Cass R. Sunstein, Lochner's Legacy, 87 Colum. L. Rev. 873 (1987). Professor Sunstein argues that West Coast Hotel represented a rejection of the Lochner Court's view that nineteenth-century common law rights established the constitutional baseline, modifications of which treaded on vested rights, and thus violated the Due Process Clause. See id. at 876-83. 
section 7; it would come into play only after we had determined the scope of statutory protection.

The concept of disloyalty necessarily seems to operate under the Act neither by trumping section 7 rights nor merely by occupying some of the space left over by section 7; rather, it functions as a guide to interpretation, a reason for choosing a narrower rather than a broader reading of section 7 . The question at hand is therefore whether section 7 can or should be read to coexist with the employer's interest in the loyalty of its employees and in its freedom from unwanted disclosures or criticism.

It would be difficult to make the case that Congress affirmatively intended to preserve the traditional duty of loyalty that employees bore toward their employer, and to limit the meaning of section 7 accordingly. It seems that the 1947 Congress, in declining to amend the relevant language of section $7,{ }^{278}$ approved the already-established withdrawal of protection from concerted activity that violated laws against violence or prolonged physical occupation of property, ${ }^{279}$ or obligations that were imposed by or strongly implicit in the Act itself. ${ }^{280}$ But even assuming those legislative views are relevant, they stop far short of approving the denial of section 7 protection on grounds of disloyalty, a dangerously pliable limitation on employee rights. ${ }^{281}$

278 The Taft-Hartley Act did amend $\S 10(c)$ of the Act to prohibit the reinstatement of an employee fired for just cause, see Pub. L. No. 80-101, § 101, 61 Stat. 136, 147 (codified as amended at 29 U.S.C. $\$ 160$ (c) (1988)), but, as discussed above, that provision should not be read as permitting discharge based on protected concerted activity on the ground that it is disloyal.

279 The Conference Report approved the Supreme Court's decision in NLRB v. Fansteel Metallurgical Corp., 306 U.S. 240 (1939), holding that $\$ 7$ did not protect employees who had engaged in a prolonged "sit-down" strike involving destruction of employer property. See H.R. Rep. No. 510, 80th Cong., 1st Sess. 38-39 (1947) [hereinafter H.R. Rep. No. 510], reprinted in SENATE SUBCOM. ON LABOR OF THE COMM. ON LABOR AND Public WELfare, 93D CONG. 2D SESS., Legislative History of the Labor MANagement Relations ACT, 1947, at 542-43 (Comm. Print 1974) [hereinafter LEGISLATIVE HISTORY OF LMRA].

280 The Conference Report on the Taft-Hartley Act also noted with approval the Board's holdings that $\S 7$ did not protect a strike to compel violation of the Act or of federal wage stabilization laws, or strikes in violation of collective bargaining agreements. See H.R. Rep. No. 510, supra note 279, at 39, reprinted in LEGISLATIVE HISTORY OF LMRA, supra note 279, at 543.

${ }_{281}$ After reporting the existing limits to $\$ 7$ protection, the Conference Report explained: "By reason of the foregoing, it was believed that the specific provisions in the House bill excepting unfair labor practices, unlawful concerted activities, and violation of collective bargaining agreements from the protection of section 7 were unnecessary." Id. The Conference Report went on to express "real concern that the inclusion of such a provision might have a limiting effect and make improper conduct 
One might still contend that the employee's duty of loyalty is inherent in the employment relationship in a capitalist society, so deeply embedded in the legal and social fabric that it need not be articulated. In promulgating a broad but not wholly unambiguous grant of employee rights such as section 7, it might be argued that Congress must have intended to preserve these basic obligations of loyalty. But this view of what Congress must have meant to do is hard to reconcile with what it did. The Court's demand for "loyalty" in Jefferson Standard seems strangely discordant in the context of a statute that explicitly protects the economic strike-that is, the deliberate and calculated imposition of economic hardship on the employer, including appeals to workers to withhold their labor and customers their patronage, for the purpose of extracting a greater share of the profits and wresting away a substantial degree of control from management. And if "disloyalty" means anything, then it would seem to encompass organizing a union, which entails soliciting other members of the workforce to introduce an outside entity whose purpose and methods are in many ways hostile to the employer and its economic self-interest. ${ }^{282}$ Every economic strike and every attempt to organize a union involves conduct that employers might rationally, and probably do in fact, regard as indefensibly disloyal. ${ }^{283}$. Yet those activities are at the heart of section 7. In the context of this statutory scheme, it is hard to sustain the claim that Congress simply took for granted the overriding obligations of loyalty that bound employees to employers under the common law, and implicitly intended to limit the scope of section 7 accordingly.

not specifically mentioned subject to the protection of the act." Id. Although Congress in 1947 may have envisioned some additional exceptions to $\S 7$, there is no basis for stretching beyond the general categories recognized at that time-that is, activity that ran afoul of specific prohibitions or policies of the Act or that was unlawful under other state laws of general application. A sweeping limitation based on a "duty of loyalty" would do just that. See NLRB v. Local Union 1229, IBEW (Jefferson Standard), 346 U.S. 464, $479-80$ (1953) (Frankfurter, J., dissenting).

282 For a recent illustration of employer views on this score, see Gatliff Business Products, Inc. 276 N.L.R.B. 543, 550, 554 (1985), in which an employer discharged employees for the "treasonous" and "disloyal" acts of supporting the union and voting in a representation election.

283 See Getman, supra note 20 , at 1238 (noting that virtually all economic pressure and union organizing could be deemed "disloyal" to the employer). Justice Frankfurter made the same point in dissent in Jefferson Standard: "Many of the legally recognized tactics and weapons of labor would readily be condemned for 'disloyalty' were they employed between man and man in friendly personal relations." Jefferson Standard, 346 U.S. at 479-80 (Frankfurter, J., dissenting). 
In outlawing the discharge of employees whom employers would reasonably regard as disloyal, Congress dramatically transformed the nature of the employment relationship. The Wagner Act represented a sharp break from the master-servant paradigm, freeing employees from onerous common law restrictions on their ability to join together with their fellow workers on matters of shared concern. A duty of loyalty by employees seems to have been constructed in Jefferson Standard out of the fragments of the employment relationship that were left on the cutting room floor in 1935 with the passage of the Wagner Act.

It might yet be argued that while the NLRA modified the nature of the employment relationship and the employee's common law duty of loyalty, it did so only.within a limited arena wherein conflict over terms and conditions of employment was viewed as inevitable, while preserving the duty of loyalty outside that arena. This is not a wholly implausible construction of the Act, though it rests on a concept of employee loyalty that has been much eroded; it is precisely beyond the arena of terms and conditions of employment that the courts are coming to recognize the overriding public interest in open discussion about the activities of both public and private employers, and thus in protecting employee expression on such matters. This construction of the Act also depends upon a limited vision of the genuine and legitimate interests of employees. Once we recognize that employees themselves have an interest in the employer's activities as they affect the public and consumers, the duty of loyalty appears to be a feeble basis for denying section 7 protection to employees who pursue that interest.

\section{B. "Managerial Prerogatives" as a Limitation on Section 7}

The "disloyalty" rationale of Jefferson Standard, even apart from its obscure pedigree, is not an especially satisfying explanation for the fundamental premise of the decision that employees have no legitimate interest in the product or service they produce or in other aspects of the enterprise they work for. To understand this broad limitation on section 7 rights, we must turn to a correspondingly broad and pervasive conception of employer rights under the NLRA: managerial prerogative.

Recall the Court's conviction in Jefferson Standard that "[ $t]$ he policies attacked were those of finance and public relations for 
which management, not technicians, must be responsible."284 This pronouncement is more than a descriptive statement of the actual interests of employees. It makes a normative claim that echoes a strong current in the interpretation of the entire statutory scheme of labor-management relations: the rights of employees created by the Act are limited by the rights of employers to run their businesses and to make basic business decisions without the interference of employees and unions.

This commitment to the prerogatives of capital and its managers pervades the interpretation of the Act. ${ }^{285}$ Decisions about the product are simply one subset of the basic managerial decisions that must be preserved, according to this prevailing dogma, from the disruptive and unwarranted interference of employees. The depth of this conviction is expressed by Justice Stewart in his influential Fibreboard concurrence: he found it "hardly conceivable" that "[d]ecisions concerning ... advertising expenditures, product design, the manner of financing, and sales" could be subject to the employer's duty to bargain, even though they might have an effect on job security and thus come within the literal scope of "conditions of employment."286 Such decisions, Justice Stewart stated, were within the "core of entrepreneurial control" that was necessarily excluded from the realm of collective bargaining under the Act. ${ }^{287}$ The opinion has been controversial as well as influential; it foreshadowed the Court's inclusion within the "core of entrepreneurial control," and hence its exclusion from the duty to bargain, of basic investment decisions that directly affect job security, such as partial or complete liquidation or expansion or contraction of the scope of a business. ${ }^{288}$ Less controversy has attended the removal

${ }^{284}$ Jefferson Standard, 346 U.S. at 476.

285 See generally ATLESON, supra note 40, at 91-107 (discussing the origins in property law of managerial prerogatives and the accommodation made to such prerogatives by the courts); Klare, Judiciul Deradicalization, supra note 105, at 298-303 (discussing early case law examining managerial prerogatives).

${ }^{286}$ Fibreboard Paper Products Corp. v. NLRB, 379 U.S. 203, 223 (1964) (Stewart, J., concurring).

287 Id.

${ }^{288}$ Id. Fibreboard itself held that there was a duty to bargain over the decision to subcontract part of the work performed by the bargaining unit. But Justice Stewart's concurrence, which sought to confine the breadth of the holding, became the basis for the Court's subsequent decision in First National Maintenance Corp. v. NLRB, 452 U.S. $666,676-77$ (1981), holding that the decision to close part of a business was within the area of entrepreneurial control preserved to unilateral management power, free from the duty to bargain. Id. at 686. The First National Maintenance decision and its conceptual foundations in the Stewart concurrence in Fibreboard have been the 
of product-related and other such decisions from the list of mandatory subjects of bargaining. ${ }^{289}$

Yet the "basic managerial prerogatives" that were deemed so important in these Supreme Court opinions are not even mentioned in the statute. Employers were granted no rights by the Wagner Act, and the rights they were granted by the Taft-Hartley Act were only rights against specific enumerated labor practices. Nowhere does the statute expressly recognize employers' right to make certain managerial decisions unilaterally.

Of course, as in the case of the duty of loyalty, employers had rights to manage their businesses, derived from state property law, before the Act. Indeed, not so long before the Act those rights were enshrined by judicial fiat in the Constitution. ${ }^{290}$ The rights of management were not eliminated by the Act, ${ }^{291}$ but they were

subject of widespread criticism. See, e.g., Staughton Lynd, Investment Decisions and the Quid Pro Quo Myth, 29 CASE W. REs. L. REV. 396, 416 (1979) (arguing that unilateral. management control over investment decisionmaking renders illusory the traditional "no-strike/arbitration tradeoff"); The Supreme Court, 1980 Term-Leading Cases, 95 HARV. L. REV. 93, 336-38 (1981) (chiding the First National Maintenance majority for its use of interest balancing in determining the scope of managerial prerogatives); Jeffrey D. Hedlund, Note, An Economic Case for Mandatory Bargaining over Partial Termination and Plant Relocation Decisions, 95 YALE L.J. 949, 953-57 (1986) (arguing that the economic rationale behind First National Maintenance fails in the absence of a perfect market); Note, Subjects of Bargaining Under the NLRA and the Limits of Liberal Political Imagination, 97 HARV. L. REV. 475, 477-80 (1983) (criticizing the distinction between mandatory and permissive subjects of bargaining as unresponsive to the interests of workers).

${ }^{289}$ Indeed, Professor Michael Harper has proposed the exclusion from mandatory bargaining of "all decisions that determine what products are created and sold, in what quantities, for which markets and at what prices." Michael C. Harper, Leveling the Road from Borg-Warner to First National Maintenance: The Scope of Mandatory Bargaining, 68 VA. L. REv. 1447, 1450 (1982) (emphasis omitted). Others, however, have questioned the basic distinction between mandatory and permissive topics of bargaining, first announced in NLRB v. Wooster Division of Borg-Warner Corp., 356 U.S. 342 (1958), in part because the categorical exclusion of certain topics is not necessarily reflective of the actual interests of employees. See HARRY H. WELLINGTON, LABOR AND THE LEGAL PROCESS 63-90 (1968); Archibald Cox, Labor Decisions of the Supreme Court at the October Term, 1957, 44 VA. L. REV. 1057, 1086 (1958); Note, Major Operational Decisions and Free Collective Bargaining: Eliminating the Mandatory/ Permissive Distinction, 102 HARv. L. REv. 1971, 1981-86 (1989); see also Rabban, supra note 127, at 711-16 (advocating abandonment of the distinction with respect to professional employees based on those employees' "professional" concerns for a wide range of matters often deemed to lie within management's prerogative); supra note 288.

${ }^{290}$ See supra note 276 and accompanying text.

291 Indeed, several supporters of the Wagner Act expressly acknowledged the employer's right to run the business. See, e.g., To Create a National Labor Board, Hearings on S. 2926 Before the Senate Comm. on Education and Labor, 73d Cong., 2d 
drastically limited by the NLRA and other New Deal legislation. Indeed, much of the legal battle leading up to the New Deal era and the Jones $\mathcal{E}$ Laughlin $^{292}$ decision upholding the NLRA was fought over the meaning of employer property rights; specifically, the extent to which the ownership of property entailed the absolute right to operate a business free from state (or employee) interference. ${ }^{293}$ The invocation of managerial prerogatives, in the guise of "property rights," to limit employee rights had a long history in 1935, with which Congress plainly determined to break. Employees were given broad rights in section 7 that necessarily undermined and compromised the managerial prerogatives that employers had before the passage of the Act. ${ }^{294}$ Just as the Act sanctions employee conduct that employers rationally regarded as "disloyal," similarly the Act sanctions and even encourages employee "interference"-by way of collective bargaining and economic pressure-with what had been considered fundamental managerial prerogatives such as setting of production schedules, use of subcontractors, determination of wages and decisions on promotion, discipline and discharge.

As in the case of "disloyalty," the concept of managerial prerogatives is pulled from outside the statutory scheme, and indeed from a legal background that was substantially repudiated in

Sess. 151 (1934), reprinted in 1 LEGISLATIVE HISTORY OF THE NLRA, supra note 183, at 181 (statement of John L. Lewis: unions "give to the corporations the right to regulate their own affairs"); 79 CONG. REC. 7673 (1935), reprinted in 2 LEGISLATIVE HISTORY OF THE NLRA, supra note 183, at 2394 (statement of Senator Walsh: it is among the "fundamental rights" of employers that "[n]o one can compel an employer to keep his factory open ${ }^{p}$ ). But what Congress did in promulgating $\$ 7$ and $\S 8$ of the Act drastically limited what had been important elements of the rights of employers to run their business. See infra text accompanying note 294. The shape and source of managerial prerogative recognized under the Act has been a major object of inquiry among labor law scholars. See ATLESON, supra note 40, at 122-35; Paul Barron, A Theory of Protected Employer Rights: A Revisionist Analysis of the Supreme Court's Interpretation of the National Labor Relations Act, 59 TEX. L. REv. 421, 438-62 (1981); Harper, supra note 289, at 1462-81; Klare, supra note 169, at 1401-03; Stone, supra note 169, at 1544-59.

292 NLRB v. Jones \& Laughlin Steel, 301 U.S. 1 (1937).

293 See supra note 276 and accompanying text.

294 Most importantly, the express prohibitions on employer interference with concerted activities, $\$ 8(\mathrm{a})(1)$ of the Act, 29 U.S.C. $\$ 158(\mathrm{a})(1)$, on discrimination against union activists, $\S 8(\mathrm{a})(3), 29$ U.S.C. $\S 158(\mathrm{a})(3)$, and on refusing to bargain, $\S 8(\mathrm{a})(5), 29$ U.S.C. $\$ 158(\mathrm{a})(5)$, represent quite drastic intrusions upon managerial prerogatives. The dramatic import of the Act does not depend on the stronger claim that it envisioned a more radical form of industrial democracy. Cf. Klare, Judicial Deradicalization, supra note 105, at 287-88 (discussing the sharp reaction by employers to the Act's "radical potential"). 
1935. When invoked to override or limit employee rights expressly granted by the NLRA, the concept of managerial prerogative should be scrutinized closely and with skepticism.

The public employee analogy is instructive here, for the preservation of managerial prerogatives is also a prominent theme in the Court's delineation of the constitutional rights of public employees. ${ }^{295}$ The Court sounded this theme in justifying the public concern test of Connick: "When employee expression cannot be fairly considered as relating to any matter of political, social, or other concern to the community, government officials should enjoy wide latitude in managing their offices, without intrusive oversight by the judiciary in the name of the First Amendment." ${ }^{296}$ And in discussing the deference to be accorded the government even when its discharge is motivated by employee speech on matters of public concern, the Court returned to this theme, stressing "the government's legitimate purpose in 'promot[ing] efficiency and integrity in the discharge of official duties, and [in] maintain[ing] proper discipline in the public service." $\$ 297$ The Court went on to observe that "the Government, as an employer, must have wide discretion and control over the management of its personnel and internal affairs. This includes the prerogative to remove employees whose conduct hinders efficient operation and to do so with dispatch.'"m298

The importance of the Court's concern for managerial prerogatives within the government cannot be overstated. Like the parallel preoccupation with managerial prerogatives under the NLRA, the imperative of public managerial discretion is invoked to justify a categorical limitation on the express rights of employees, here under the First Amendment. But the "core of managerial control" reserved to the government employer is precisely the opposite of that recognized under the NLRA: It encompasses those matters

295 See, e.g., Cleveland Bd. of Educ. v. Loudermill, 470 U.S. 532, 546 (1985) (recognizing "the government's interest in quickly removing an unsatisfactory employee"); Connick v. Myers, 461 U.S. 138, 146, 150-51 (1983); Bishop v. Wood, 426 U.S. 341, 349-50 (1976) (holding that the Due Process Clause does not protect employees from "incorrect or ill-advised personnel decisions"). See generally Lieberwitz, supra note 7, at 646-48 (arguing that Connick shifted the theoretical basis of speech protection by judging the utility of public employee speech by its value to the economic system rather than the political system).

296 Connick, 461 U.S. at 146.

297 Id. at 150-51 (quoting Ex parte Curtis, 106 U.S. 371,373 (1882)).

${ }^{298}$ Id. at 151 (quoting Arnett v. Kennedy, 416 U.S. 134, 168 (1974) (Powell, J., concurring)). 
most closely related to the terms and conditions of employment of the protesting employees and thus is held to justify the unfettered power to discharge employees engaged in work-related protests.

These contrasting conceptions of managerial prerogative raise an intriguing question: how is it that public enterprises would be crippled by the protection of employee speech on terms and conditions of employment, while private enterprise would suffer most by permitting employee protest directed at those aspects of the business most remote from terms and conditions of employment, such as product quality? Stated differently, if private industry can function, as it has for 50 years, under a regime that prohibits the discharge of employees for protesting their terms and conditions of employment, then why could the public employer not tolerate the same type of dissent? Conversely, and more importantly for present purposes, if the public employer is not disabled by permitting criticism on "matters of public concern" such as "product quality," then why should we worry that the private employer could not survive such criticism as well?299 Unless there is some fundamental difference in the way public and private managers do and must manage their enterprises, the fear of undermining basic managerial prerogatives seems to be exaggerated in both sectors. Several decades of experience with employee speech rights in both public and private employment suggest that both public and private managers can well tolerate dissent of both the public-spirited and the self-interested variety.

Of course there are some basic differences in the nature of public and private managers. Two such differences seem potentially relevant here: First, most private employers are in competition with others; public agencies rarely face such competition. Second, management of a private company is accountable to the company's owners, and is charged with making a profit for those owners; management of a public agency is charged with serving the public and is ultimately accountable to the public. Do these differences undermine the claim that private sector managers, like public sector managers, should be required to tolerate public disclosures by employees on matters of concern to the public?

The competitive context within which private employers operate does render employers more vulnerable to employee disclosures of this sort. Such disclosures may hurt the private employer more than

${ }^{299}$ See Blumberg, supra note 271, at 298-307. 
they would hurt public employers if only because those consumers or other customers who might be influenced by the damaging disclosure generally have someplace else to turn; they can take their business to a competitor. But it is not clear that this sort of competitive injury is something that we-that is, the public and its governmental and judicial agents charged with interpreting the Actought to be especially concerned about.

We must begin by recognizing that only basically truthful disclosures would be protected, for section 7 does not protect speech that is deliberately or recklessly false and defamatory. ${ }^{\mathbf{3 0 0}}$ Moreover, only information that the public cares about and does not already know will have any significant harmful effect on the employer. ${ }^{301}$ The employer and its ability to compete will be hurt only if the information that is disclosed influences consumers in their choice of product or persuades other important third partiesfinancial institutions, contributors, public oversight bodies, corporate customers or suppliers-to take some action to the detriment of the employer. If it is clear enough why the employer has an interest in discouraging disclosure of that sort of information, it is far less clear why the rest of the society should accommodate this interest by permitting the discharge of employees who make such disclosures. ${ }^{302}$ Rather, the harmful effects feared by

${ }^{300}$ See Linn v. United Plant Guard Workers, Local 114, 383 U.S. 53 (1966) (adopting "actual malice" test of New York Times v. Sullivan, 376 U.S. 254 (1964), as test for what speech is unprotected by $\S 7$ and thus actionable under state defamation law). Concededly, some misleading opinions and some unprovable false statements may end up being protected; as in libel actions it is likely that the employer will bear the burden of proof of "actual malice" and falsity to strip employees of $\$ 7$ protection. But by and large damaging falsehoods will not be protected.

${ }^{301}$ Concededly, other kinds of disclosures or internal dissent may have disruptive effects within the organization-undermining managerial authority or sowing employee discontent-but I can see no reason why those effects would be any greater than the effects of dissent concerning terms and conditions of employment, which is already protected. On the contrary, the Act contemplates and sanctions very dramatic disruptions, such as strikes, as a potential consequence of the exercise of $\$ 7$ rights. See supra text accompanying notes 110-121.

302 There are many ways in which costs to the firm could impose society-wide costs. For example, firms might respond to the proposed expansion of employee rights by attempting to limit the dissemination of potentially damaging information within the firm; this would presumably entail the inefficient use of resources to keep information secret and a loss of productivity that would otherwise follow from employee access to such information. Such a response might also appear likely to deter management from expanding employee involvement in decisionmaking in matters such as product quality: to the extent that employee participation requires wider dissemination of information, it would entail a greater risk of damaging public disclosures by employees. 
the employer would seem simply to be the consequence of better informed decisions in both the private and public sectors.

Much the same analysis holds with respect to the differing missions of private and public employers and the different bodies to which they are responsible. It is true that, for public employers, there is no cognizable conflict between the interest of the public in receiving information and the interests of management, since management is responsible ultimately to that same public. Private management, on the other hand, responds to private ownership, whose interest in maximizing profits may well conflict with the interests of the public in disclosure of potentially damaging information. But does this difference justify the failure to protect employee disclosures on matters of interest to the public?

Given the competitive context within which firms operate, the owners or shareholders of firms subjected to damaging disclosures may well suffer as a result. But other firms will probably benefit from increased business to roughly the same extent. It is hard to see what public interest is served by favoring the former over the latter. Again assuming that the information is generally true and of enough concern to consumers or other economic actors to influence their decisions in the market, the public interests served by protecting disclosure seem at least as strong as the private interests of one set of owners in the competitive advantage that they might gain by prohibiting disclosure.

We are compelled to choose among plausible interpretations of the scope of employee rights to criticize their employers and to disclose information that might lead consumers and others to disfavor the employer. The existing narrower interpretation of those employee rights, which limits employees to discussing matters directly relevant to the terms and conditions of their employment,

It is beyond the scope of this Article to evaluate the economic costs entailed by the proposal. Nevertheless, I do not believe these costs would prove a major problem. The extent and likelihood of damaging public disclosures by employees would not be materially incerased by the proposal given, first, the formiddable deterrents faced by employees contemplating disclosure, see supra text accompanying notes 214-33, and second, the existing risk of disclosures protected under current law. The costs entailed by such disclosures might be ameliorated or perhaps even outweighed by the benefits to the firm of internal dissemination of information. THose benefits might include, in the case of a firm expanding employee involvement , increased employee satisfaction with work and commitment to the enterprise. See supra text accompanying note 139. Indeed, increased employee satisfaction itself might even decrease the likelihood of public disclosures by employees. (I thank my colleague Henry Hu for helping to clarify these matters.) 
is supported by employers' private interest in maximizing profits by preventing and punishing disclosure of information that might affect marketplace decisions. The broader interpretation advocated here is supported not only by the interests of employees in being free to discuss and act upon the full range of issues of concern to them in their work lives, but also by the interest of the public in gaining significant information about the activities of private enterprises that might otherwise not become known.

\section{CONCLUSION}

The employer interests that seem to push against a broader conception of the interests of employees under section 7 turn out upon scrutiny not to be grounded in or even easily reconcilable with the Act. Moreover, the interests of private management in discouraging employee protests of this nature are not particularly compelling candidates for public recognition: to a great extent, employers will be harmed only to the extent that the public has gained information about them that it deems useful. The public interest in that information has, I submit, as good a claim for consideration under the statute as the interests of employers-already deeply and deliberately compromised by the Act-in employee loyalty and managerial prerogative.

But the key to expanding the scope of section 7 to include employee protest directed at the product or service or nonlabor practices of the employer is a richer understanding of the interests of employees in these matters. The seamless continuity between economic self-interest in workplace disputes and the loftiest concerns of the polity was perhaps better apprehended several decades ago, when issues such as labor unrest and the distribution of wealth were at the forefront of national political debate. These currents are reflected most clearly in Thornhill $v$. Alabama, ${ }^{303}$ in which the Court held that peaceful labor picketing was protected by the First Amendment. ${ }^{304}$ In striking down a state antipicketing statute, the Supreme Court declared:

In the circumstances of our times the dissemination of information concerning the facts of a labor dispute must be regarded as within the area of free discussion that is guaranteed by the Constitu-

303310 U.S. 88 (1940).

${ }^{304} \mathrm{See} i d$. at 105-06. The decision was based on the ground of facial overbreadth. See id. at $96-98$. 
tion.... The health of the present generation and of those as yet unborn may depend on these matters, and the practices in a single factory may have economic repercussions upon a whole region and affect widespread systems of marketing. ... [L]abor relations are not matters of mere local or private concern. Free discussion concerning the conditions in industry and the causes of labor disputes appears to us indispensable to the effective and intelligent use of the processes of popular government to shape the destiny of modern industrial society. ${ }^{\mathbf{3 0 5}}$

The constitutional status of labor speech, and especially labor picketing, has declined dramatically since $1940.0^{306}$ Restrictions on labor picketing that would not survive the strict scrutiny ordinarily demanded by the First Amendment have been approved under the sort of deferential balancing analysis used for mere economic legislation. ${ }^{307}$ The relegation of labor expression to the realm of private economic activity has largely removed constitutional hurdles to the enforcement of statutory restrictions on most "secondary" appeals, by which labor might more effectively seek the support of fellow workers, consumers, and the public generally. ${ }^{308}$ Connick suggests an explanation for the decline: workplace issues generally have come to be viewed as matters of merely private significance, with little relevance to "matters of public concern. ${ }^{n 09}$

${ }^{305} \mathrm{Id}$. at 102-03.

306 See James G. Pope, Labor and the Constitution: From Abolition to Deindustrialization, 65 TEX. L. REV. 1071, 1094-96, 1113-18 (1987); Cynthia Estlund, Note, Labor Picketing and Commercial Speech: Free Enterprise Values in the Doctrine of Free Speech, 91 YALE L.J. 938, 940-41 (1982) [hereinafter Note, Labor Picketing]; Mark D. Schneider, Note, Peaceful Labor Picketing and the First Amendment, 82 CoLUM. L. REv.1469, 147595 (1982).

${ }^{307}$ See Pope, supra note 56, at 914-19; Note, Labor Picketing, supra note 306, at 943 47.

${ }^{308}$ See NLRB v. Retail Store Employees Union, Local 1001, 447 U.S. 607, 616 (1980) (dismissing in one paragraph a First Amendment challenge to the secondary boycott provisions of the NLRA). Those restrictions would be manifestly unconstitutional if applied to speech on "public issues," such as a consumer boycott instituted as a civil rights protest. See NAACP v. Claiborne Hardware, Co., 458 U.S. 886 (1982).

${ }^{309}$ Connick, 461 U.S. at 152; see also Claibarne Hardware, 458 U.S. at 913 (distinguishing labor picketing from civil rights picketing in support of a consumer boycott by characterizing the former as economic activity and the latter as "public issues"); Carey v. Brown, 447 U.S. 455, 471 (1980) (rejecting on equal protection grounds an antipicketing ordinance that exempted peaceful labor picketing). See generally Pope, supra note 56, at 921-22 (discussing the Court's use of the politicaleconomic distinction). The development of this distinction is ironic, in that the very first subject denominated a "matter of public concern" by the Supreme Court was the labor dispute at issue in Thomhill. Contrary signals appear in the Court's more 
The same uncoupling of "labor relations" from public affairs-an about-face from the powerful pronouncements of Thornhill-seems to be at work as well behind the constraints on section 7 doctrine manifested in Eastex and Jefferson Standard: politics, product quality, public safety and environmental concerns are not within the separate and lesser realm of "labor relations" covered by section 7 . Just as the public is not thought to be especially concerned about what goes on within the private-sector workplace between labor and management, workers are not thought to have a substantial and legitimate interest in how the work they do affects their communities.

Thornhill cloaks ordinary labor disputes in the shimmering fabric of self-government. Perhaps the rhetoric of Thornhill, rather than the retreat that followed, was an aberration in American jurisprudence. But it captured a truth that is missing in both the First Amendment treatment of public employee speech and the section 7 protection of private employee protest: personal experiences and interests in the workplace transform, and in turn are transformed by, concerns about the community and the society at large. This Article aims to recapture that insight in the context of section 7: Employees who join together and express their shared concerns about how their work and their enterprise affect the world are indeed engaged in "concerted activity for mutual aid or protection."

recent decision in Edward J. DeBartolo Corp. v. Florida Gulf Coast Building \& Construction Trades Council, 485 U.S. 568, 575-78 (1988), in which the Court construed $\S 8(\mathrm{~b})(4)$ of the NLRA, 29 U.S.C. $\$ 158(\mathrm{~b})(4)(1988)$, not to proscribe union handbilling in support of a secondary consumer boycott. The Court did so to avoid what it termed "serious constitutional issues" raised by a contrary construction of the Act. Edward J. DeBartolo, Corp., 485 U.S. at 576. According to the Court, these constitutional issues arose in part because the challenged leaflets, beyond soliciting support in the particular labor dispute, "pressed the benefits of unionism to the community and the dangers of inadequate wages to the economy and the standard of living of the populace." Id. 